\title{
The Once and Future Property-Based Vision of the First Amendment
}

\author{
John O. McGinnis $\dagger$
}

\section{INTRODUCTION: THE FIRST AMENDMENT AND CHANGING SOCIAL THOUGHT}

The growth of the information superhighway depends not only on technological developments, but also on our society's commitment to the free flow of information. Paradoxically, however, as the digital revolution in telecommunications is bringing the information superhighway into sharp focus, the justifications for contemporary First Amendment jurisprudence are becoming blurred.

For about the last fifty years, free speech has been the preeminent constitutional right, continually expanded by Supreme Court justices of varying jurisprudential views to protect ever more varied and vigorous expression. With few exceptions, this development has been welcomed by jurists and academics across the political spectrum. Given this consensus, the concept of freedom of speech has also taken deep roots in our popular and political culture. ${ }^{1}$ Now, however, the social paradigm that was the source of the expansion is being challenged, and with it the foun-

$\dagger$ Professor of Law, Benjamin N. Cardozo Law School <McGinnis@yu1.yu.edu>. (C) 1996 John O. McGinnis. My thanks to John Beckerman, David Bernstein, David Gray Carlson, Benedict Cohen, Edward deGrazia, Robert Delahunty, Richard Epstein, John Harrison, Marci Hamilton, Michael Herz, Owen Jones, Mark Lemley, Nelson Lund, John Manning, Mark Movsesian, Burt Neuborne, Bill Patry, Monroe Price, Michel Rosenfeld, Paul Shupack, Stewart Sterk, Daniel Troy and Eugene Volokh for helpful comments on various drafts. I also am grateful to colleagues at faculty workshops at Cardozo and Seton Hall. The variety of their questions and critiques provided yet more support for a theory of the First Amendment that puts the individual first. Jason Lief supplied splendid research and editing assistance. Thanks too to Daniel Goldfisher and Dara Norman for assistance with the terminology of cyberspace.

I should note that as an attorney in the Reagan and Bush administrations I was involved in formulating their position on the fairness doctrine-an issue briefly discussed in this Article.

1 See Steven Shiffrin, The Politics of the Mass Media and the Free Speech Principle, 69 Ind L J 689, 716 (1994) (concluding that the free speech principle is more "solidly anchored" in our culture than ever before). In this paper, unless otherwise indicated, I use the term "First Amendment" as a shorthand for the Free Speech and Free Press Clauses. 
dations of the First Amendment theory that protected so much expression.

Much of the impetus for the First Amendment's ascension to the apex of constitutional law lies in the New Deal's ideal of social democracy and the subsequent transformation of the federal government into a vigorous instrument of social reform. To gain the centralized authority necessary for large scale social reform, the federal government had to liberate itself from the features of the original design that had been intended to limit its power. ${ }^{2}$ Thus, the structural checks of federalism and separation of powers were substantially weakened. ${ }^{3}$ Moreover, substantive restraints on governmental programs imposed by constitutionally protected property rights all but disappeared. ${ }^{4}$ With the dissolution of these venerable checks on the power of the state, the Court had to look elsewhere for a mechanism for restraining such power, and located it in the reasoned deliberations of citizens in the democratic process. ${ }^{5}$ Under this new model, the citizens' ability to engage in sustained social criticism and vote their rulers out would prevent a powerful state from becoming a tyrannical one.

If the ability of citizens to criticize and ultimately replace the government was to contain the power of the state, the First Amendment naturally had to take center stage as the principal means of guaranteeing "open political dialogue and process." If

2 As discussed below, the original Constitution envisaged a limited government whose primary purpose was to protect individual rights, rather than to reform society through collective processes. See notes $84-86,125$ and accompanying text.

${ }^{3}$ For a discussion of the collapse of federalism, see Richard A. Epstein, The Proper Scope of the Commerce Power, 73 Va L Rev 1387 (1987). For a discussion of the collapse of separation-of-powers restraints, see Gary Lawson, The Rise and Rise of the Administrative State, 107 Harv L Rev 1231, 1248-49 (1994).

4 See, for example, West Coast Hotel Co. $v$ Parrish, 300 US 379 (1937) (rejecting the notion that existing property distributions deserve special protection). The transformation of social thought that led to the declining willingness of the courts to enforce economic liberties is detailed in G. Edward White, From Sociological Jurisprudence to Realism: Jurisprudence and Social Change in Early Twentieth-Century America, 58 Va L Rev 999 (1972).

5 See David Yassky, Eras of the First Amendment, 91 Colum L Rev 1699, 1734-37 (1991) (understanding increased First Amendment protections after the New Deal as a way of preserving majority control of the newly empowered state). The theory of the First Amendment developed in the post-New Deal era to promote democratic deliberation was not entirely novel; it had roots in the progressive era and in the theories of Zechariah Chafee, Jr. See Mark A. Graber, Transforming Free Speech: The Ambiguous Legacy of Civil Libertarianism 125 (California 1991) ("In [Chafee's] writings, free speech was ... a procedural prerequisite of any democratic society."). See also id at 122-26, 140-64 (describing Chafee's theory of free speech).

6 See John Hart Ely, Democracy and Distrust: A Theory of Judicial Review 112 (Har- 
the government were to engineer fundamental social change, free speech had to encourage the widest possible dissemination of social ideas and political programs. Moreover, free speech was needed so that constant criticism of the results of past reform could be used to improve future schemes. ${ }^{7}$ On this view, although the First Amendment protected all sorts of political expression, it was no longer understood as a right of the individual, like a right of property. ${ }^{8}$ It was instead understood as an essential social instrument through which citizens could be assured of a continual ability to rationally and collectively plan for a better world. ${ }^{9}$

Although the perfection of collective democratic processes was the most important rationale for the expansion of free speech during this period, it was not the only one. The architects of the new consensus believed that the economic arrangements of civil society-the order created by the exercise of property rights-should be subject to perpetual revision and control through the central government. ${ }^{10}$ They also recognized, howev-

vard 1980) (stating that the "central function" of the First Amendment is to "assur[e] an open political dialogue and process").

7 See, for example, Roth $v$ United States, 354 US 476, 484 (1957) (The First Amendment "was fashioned to assure unfettered interchange of ideas for the bringing about of political and social changes .....").

* This new theory replaced a more self-consciously libertarian theory of the First Amendment, now all but forgotten, that was popular in the late nineteenth and early twentieth centuries. The previous view had protected speech rights by equating them with property rights; both were natural rights of the individual that the government had only a limited power to regulate. See Graber, Transforming Free Speech at 18 (cited in note 5) (listing a host of theorists and judges who believed that "a legislature had no more business regulating expression than it had regulating property"). See also id at 17-49 (describing views of conservative libertarians who equated speech and property rights). Some of the judicial decisions from that era presage the theory of the First Amendment offered in this Article. See note 187.

${ }^{3}$ Indeed, by the 1960 s this transformation had gone so far that the leading theorist of the First Amendment expressly cast the First Amendment entirely as a right of governance, not as a right of the individual:

The First Amendment does not protect a "freedom to speak." It protects the freedom of those activities of thought and communication by which we "govern." It is concerned, not with a private right, but with a public power, a governmental responsibility.

Alexander Meiklejohn, The First Amendment is an Absolute, 1961 S Ct Rev 245, 255. John Hart Ely also interpreted the Warren Court's First Amendment jurisprudence, and indeed its civil rights jurisprudence generally, as an attempt to perfect the democratic process. See Ely, Democracy and Distrust at 105-25 (cited in note 6).

${ }^{10}$ For a discussion of this aspect of the New Deal consensus, see Cass R. Sunstein, The Partial Constitution 40-67 (Harvard 1993). 
er, the need for a personal sphere beyond the reach of centralized authority, within which individuals could work to achieve selfrealization. Indeed, it was the existence of this personal sphere that they felt was one of the most important demarcations separating the modern welfare states of the West, including the United States, from the communist states of the East.11 Once again, the First Amendment stepped to the fore because it seemed a perfect instrument for protecting this personal sphere. ${ }^{12}$ Nonpolitical speech was understood as a means to selfrealization that could be distinguished from market processes. ${ }^{13}$ Although, in a social democracy, economic enterprise was viewed as an engine of exploitation and inequality necessarily subject to strict government supervision, expressive activity was seen as merely personal and thus beyond the need for government control. Hence, in the model of social democracy, the First Amendment as a right of self-expression thrived in symbiosis with the First Amendment as an instrument of self-governance to provide substantial safeguards for both political and nonpolitical speech. ${ }^{14}$

11 See Richard Lowenthal, The Future of Socialism in the Advanced Democracies, in Leszek Kolakowski and Stuart Hampshire, eds, The Socialist Idea: a reappraisal 222, 22225 (Weidenfeld \& Nicolson 1974) (stating that Western social democracy, unlike communism, seeks a regime that combines personal autonomy with social control over economic forces).

${ }_{12}$ See Martin H. Redish, The Value of Free Speech, 130 U Pa L Rev 591 (1982). The self-realization strand of First Amendment theory was not entirely novel. Before the New Deal, social radicals, such as anarchists and advocates of free love, championed robust First Amendment protections to promote individual autonomy in the personal sphere. See David M. Rabban, The Free Speech League, the ACLU, and Changing Conceptions of Free Speech in American History, 45 Stan L Rev 47, 52-54 (1992). For a general history and discussion of the organized groups that defended freedom of expression in the era before World War I and the founding of the ACLU, see id at 47-99.

${ }_{13}$ See C. Edwin Baker, Realizing Self-Realization: Corporate Political Expenditures and Redish's The Value of Free Speech, $130 \mathrm{U}$ Pa L Rev 646, 653-54 (1982) (distinguishing free speech that allows self-realization from speech dictated by the market).

${ }_{14}$ See Thomas I. Emerson, The System of Freedom of Expression 6-7 (Random House 1970) (envisioning the First Amendment from the dual perspective of self-realization and self-governance theories).

The social democratic expansion of the First Amendment, of course, was not embraced with the same fervor by all points on the political and jurisprudential spectrum. Not surprisingly, egalitarian social democrats, seeking both a powerful, democratically legitimated government and a personal sphere of autonomy and self-realization, were the strongest supporters of both rationales for broad readings of the First Amendment. Conservatives and libertarians did not celebrate powerful governmental entities designed to revise private economic arrangements. However, conceding that a powerful state existed, conservatives and libertarians agreed that public debate might improve, and perhaps even restrain, the overweening state. Thus, they largely acquiesced in the political process rationale for First Amendment expansion, although conservatives often sought to except extremist speech from the ambit of the Amendment's protection. See Robert $\mathrm{H}$. Bork, Neutral Principles and Some First Amendment Problems, 47 Ind I J 1, 20 (1971) 
The foundations on which the First Amendment theories of the last several decades have rested are collapsing for two interrelated reasons. First, the New Deal consensus on the role of government has dissipated. At the level of election returns, the party opposing the expansion of the state has been making substantial electoral gains. ${ }^{15}$ The election returns themselves, however, are but epiphenomena of deeper difficulties for the social democratic paradigm exemplified by the New Deal. Public choice theory has cast doubt on the coherence and efficacy of collective decision making. ${ }^{16}$ Furthermore, the rise of natural, as opposed to merely cultural, explanations for human social ordering raises questions about the malleability of human society. ${ }^{17}$ For instance, under a view emphasizing the natural roots of human behavior, rent seeking-the practice by which one faction uses the democratic process to expropriate the wealth of another-is

(suggesting that political speech should be protected by the First Amendment, but making an exception for extremist speech that calls for the forcible overthrow of the government). Many traditional conservatives were much less enthusiastic about the self-realization rationale for the protection of First Amendment rights because they believed that such expression could disrupt the delicate harmony of civil society, which in their view depended on the acceptance of traditional social norms and proprieties. See Donald Alexander Downs, The New Politics of Pornography 27-28, 101-03 (Chicago 1989) (discussing traditional conservatives' interest in regulating pornography). Nevertheless, the views of traditional conservatives rarely prevailed, as the First Amendment was expanded to protect indecent and offensive expression. See, for example, Cohen $v$ California, 403 US 15 (1971) (public display of expletive protected by the First Amendment); Erznoznik $v$ City of Jacksonville, 422 US 205 (1975) (invalidating city ordinance making it a public nuisance for a drive-in movie theater to show nudity if movie screen is visible from public area).

${ }_{15}$ See Dan Balz, GOP Takes Over; House Sets Off at Quick Pace: Euphoric Republicans Ready for Great Debate on Government's Role, Wash Post A1 (Jan 5, 1995) (discussing historic realignment of the 1994 congressional elections).

${ }^{16}$ See Dennis C. Mueller, Public choice II: A revised edition of Public Choice 406 (Cambridge 1989) (stating that modern public choice theorems "raise fundamental questions about the possibility of establishing collective choice procedures satisfying minimally appealing normative properties").

${ }_{17}$ It is impossible to open the newspaper or enter a bookstore without being confronted by arguments that stress the natural constraints on social ordering. One recent example of a best-selling book offering such explanations is Robert Wright, The Moral Animal: Evolutionary Psychology and Everyday Life 3-15 (Pantheon 1994) (arguing that human society is structured around the human mind, which was adapted through evolution). While these kinds of arguments have reached the general public only recently, a revival of biologically based explanations of human behavior and social structure has been underway in the social sciences for the last two decades. See, for example, Carl N. Degler, In Search of Human Nature: The Decline and Revival of Darwinism in American Social Thought (Oxford 1991) (describing the rise of evolutionary thinking in psychology, linguistics, anthropology, and economics). For a discussion of the way in which the renewed importance of human nature in the social sciences may move the interpretation of the entire Constitution back toward its original meaning, see John O. McGinnis, The Original Constitution and Our Origins, 19 Harv J L \& Pub Policy (forthcoming 1996). 
seen as an inherent difficulty of collective decision making, because individuals are designed by hundreds of thousands of years of evolution to seek wealth and status for themselves. ${ }^{18}$ Finally, insofar as human society is ordered in relatively intractable ways, a governmental structure designed to facilitate large-scale and continuous revision of social arrangements seems generally less attractive. ${ }^{19}$

If social democracy is likely to be less coherent and less effective than once thought, there is less reason to understand the First Amendment as a means to protect information inputs for facilitating the collective democratic process. More information, for instance, is not going to create a coherent agenda of social reform if incoherence is an inevitable result of pooling individual preferences through democratic decision making. ${ }^{20}$ Nor is more information going to change the biologically based nature of man that drives costly rent seeking in the democratic welfare state. The collective governance rationale for protecting speech weakens as the old social democratic paradigm begins to lose its luster.

In addition to the dissipation of the New Deal consensus on the role of government, the self-realization rationale of past decades is also being eroded. Information transmission is now increasingly understood to be identical in important aspects to the

${ }_{18}$ See generally Mueller, Public choice II at 229-46 (cited in note 16) (discussing rent seeking and its implications for political processes). Indeed, there is a close connection between the rise of public choice as an explanation for law and politics and the rise of evolutionary biology in the social sciences generally. Public choice explains political actions as motivated by the rational self-interest of individual actors. See Daniel A. Farber and Philip P. Frickey, Law and Public Choice: $A$ Critical Introduction 22 (Chicago 1991). Evolutionary biology explains why such self-interest is likely to be hard-wired in man. See Wright, Moral Animal at 336-37 (cited in note 17) ("[S]elf-absorption is the hallmark of life on this planet. Organisms are things that act as if their welfare were more important than the welfare of all other organisms (except [ ] when other organisms can help spread their genes).").

19 This point about the difficulty of social reform does not rest simply on the fact that much human behavior is rooted in our biological nature. Even social scientists who believe that there is an important biological component of human behavior agree that the behavior is a result of a complex interaction between nature and environment. See Wright, Moral Animal at 8-9 (cited in note 17). The environment, however, is itself a very diffuse phenomenon, and we generally know relatively little about how to manipulate it so that the resulting interaction with the natural impulses and endowments of man will change social behavior for the better. See, for example, James Q. Wilson, From Welfare Reform to Character Development, Address Before the Manhattan Institute for Policy Research 9, 19-20 (Nov 17, 1994) (on file with U Chi L Rev) (observing difficulty of reducing the rate of illegitimacy by changing the environment).

${ }_{20}$ For an explanation of why collective decision making that uses the intuitively appealing properties desired by most democracies results in inconsistency, see Mueller, Public choice II at 384-407 (cited in note 16) (describing various social welfare functions). 
economic activity attendant to the exchange of material property. ${ }^{21}$ First, information is more than ever seen as a product to be exchanged, formally and informally, and as a prime source of wealth in society. ${ }^{22}$ Even when a product is not itself information-based, expression, in the form of advertising, creates the market for material products. Moreover, research into our evolutionary heritage confirms that the human faculty of speech evolved to improve economic well-being, both by facilitating the exchange of goods and by creating another product for exchange-namely information itself. ${ }^{23}$ Information production of all kinds is thus increasingly seen as directed toward the acquisition of wealth and status, and no longer seems well suited for carving out a sphere of self-realization that is separate from the market. ${ }^{24}$ Expressive man is economic man.

One of the consequences of the crisis confronting the old rationales for the First Amendment is that the left and right sides of the political spectrum in the United States are increasingly switching sides on free speech issues. ${ }^{25}$ If information transmission is understood as intertwined with the market-becoming an extension, indeed a source, of inequality rather

${ }^{21}$ Indeed, the very name increasingly given to our age-the Information Age-suggests that expression of any kind is not a category easily confined to the personal sphere.

${ }_{22}$ See Walter B. Wriston, The Twilight of Sovereignty: How the Information Revolution is Transforming Our World 18-39 (Scribner's Sons 1992) (arguing that information has itself become an important source of wealth). During the 1980s the United States invested over one trillion dollars in information technology. See Fred H. Cate, The First Amendment and the National Information Infrastructure, 30 Wake Forest L Rev 1, 5 (1995), citing Howard Gleckman, The Technology Payoff, Bus Week 57 (June 14, 1993). Over one half of employees in the United States work in information-based jobs. Cate, 30 Wake Forest L Rev at 5.

${ }^{23}$ For a discussion of the evolution of speech and the advantages it provided in facilitating the exchange of information and other goods, see Steven Pinker, The Language Instinct 365-69 (Morrow 1994). For more complete discussion of the implications of the evolving uses of speech for understanding the First Amendment, see John O. McGinnis, Information Transmission and Human Nature: Evolutionary Biology and Free Speech (on file with U Chi L Rev).

${ }^{24}$ Professor Kathleen Sullivan recently suggested that speech activity is fundamentally different from economic activity because speech seeks to change individuals' preferences while consumer goods seek to serve these preferences. See Kathleen M. Sullivan, Free Speech and Unfree Markets, 42 UCLA L Rev 949, 963 (1995). This distinction is open to doubt: over the course of human history, new technologies and goods have changed preferences as much as new ideas. Indeed, whole theories of history see political ideas as driven by technological change. In any event, the point here is that individuals express themselves primarily for the same reason they engage in material market activities: to advance their position in the world.

${ }^{25}$ For a discussion of the changing leftist thought on free speech, see John $O$. McGinnis, The Left vs. Free Speech, 100 Commentary 59 (Oct 1994). 
than an essential part of the process for remedying it-the left will look more kindly on regulation of speech. Likewise, if information transmission is at bottom a means of wealth creation, rather than merely self-expression likely to disturb the social fabric, the right will be less eager to regulate it. ${ }^{26}$ This change of positions is confirmed in academic writings and case law; whether the issue is hate speech, commercial speech, or supervision of the information superhighway, the left is more inclined to regulate and the right is more inclined toward laissez-faire. ${ }^{27}$ When Harvard University awards a prize to a book that calls for more government regulation of speech in the interest of promoting democracy, epochal change is in the air. ${ }^{28}$

This Article chooses a road that diverges sharply from that taken by current self-governance theorists of the First Amendment. It seeks to cleanse the First Amendment of the obscuring varnish of social democracy and reveal its true origins as a property right of the individual, thus providing a model for an emerging laissez-faire jurisprudence. In fact, the property-centered vision of the First Amendment offered here reflects the views of its principal drafter: James Madison. ${ }^{29}$ While contemporary scholars have utterly and inexplicably ignored Madison's property-centered vision of the First Amendment, Madison believed that individuals possessed a property right in their ideas and opinions just as surely as they possessed a property right in the material goods they fashioned. Madison also understood that the ability to transmit information, either through one's own person (free

${ }^{26}$ For another interesting analysis of the reasons the left is now interested in speech regulation, see Burt Neuborne, Blues for the Left Hand: A Critique of Cass Sunstein's Democracy and the Problem of Free Speech, 62 U Chi L Rev 423, 429 (1995) (suggesting that the lack of enthusiasm for robust free speech is that left-leaning reformers "currently lack an affirmative political program of their own").

${ }^{27}$ See Shiffrin, 69 Ind L J at 689-91 (cited in note 1) (discussing the reversal of the positions of the left and the right on First Amendment issues).

${ }^{28}$ The Joan Shorenstein Barone Center on the Press, Politics and Public Policy at the John F. Kennedy School of Government at Harvard awarded the Goldsmith Book Prize to Cass R. Sunstein's Democracy and the Problem of Free Speech (Free Press 1993). For a discussion and critique of this book's prescriptions for more regulation of speech, see notes 288-321 and accompanying text.

While Sunstein's redeployment of the self-governance theory in the service of increased regulation may seem curious at first, it is in fact a logical outcome of that theory's underlying structure. Because the self-governance theory views free speech as an instrument of a collective good-social democracy-rather than as an end in itself, the deregulation that it previously promoted was always contingent on the usefulness of free speech toward that good. Regulation becomes appropriate when a new understanding of the effects of speech makes regulation necessary for advancing the cause of social reform.

${ }^{29}$ For a fuller discussion of the drafting history of the First Amendment, see Part I. 
speech) or through the use of other material property (free press) needed special protection from government interference. ${ }^{30} \mathrm{Be}-$ cause information transmission can threaten the interests of the rulers more substantially and more immediately than material production, rulers have a greater incentive to suppress and regulate these rights. On this view, however, the function of the First Amendment is not to promote the collective interest in self-governance; the function of the First Amendment is to prohibit regulation of an important property right peculiarly threatened by the government.

Although the construction of the Free Speech and Free Press Clauses that emerges from the property-based view of the First Amendment is rooted in the natural rights of the individual, ${ }^{31}$ it also results in substantial social benefits, particularly in the Information Age. Indeed, I argue that a property-based system in which the First Amendment simply protects the individual's right to transmit his information is more likely to result in sound collective governance, and the accumulation of socially beneficial knowledge, than a system of information transmission regulated by a central sovereign authority for any reason other than to prevent the loss of property or life through force or fraud. ${ }^{32}$

The growth of cyberspace-the medium replacing the traditional press and television as the primary medium of communication-promises infinitely expandable opportunities for the transmission of ideas, opinions, promises, and commitments. In so doing, cyberspace makes the property-based vision an even more robust conceptualization of the First Amendment than it was in Madison's time. ${ }^{33}$ To be sure, scarce resources such as telephone

35 I define "information" in this article broadly. As Professor Farber suggests, our common usage of the term encompasses speech that "does not necessarily communicate... new data." See Daniel A. Farber, Free Speech Without Romance: Public Choice and the First Amendment, 105 Harv L Rev 554, 555 n 8 (1991). For instance, many forms of argument offer new ways of looking at old data; they are nevertheless valuable. See id. Indeed, I would include within my definition of information not only statements that reveal objective data but also statements that reveal an individual's affect toward another or his future course of conduct. Such information also may be of great value to the individual who transmits it. For further development of these ideas, see text accompanying notes 141-46.

31 The implications of the property-based vision for First Amendment doctrine are sketched in Part II.

${ }_{32}$ In Part IV, I argue that the property-based model of the First Amendment is paradoxically more successful than either the self-governance or self-realization models in promoting the goals of self-governance and self-realization.

${ }_{33}$ Part III discusses the implications for cyberspace and emerging telecommunications media. In particular, it shows that the Supreme Court, in Turner Broadcasting System, Inc. v FCC, 114 S Ct 2445 (1994), failed to appreciate the property-centered 
wires, satellites, and other networks are needed to create cyberspace, but modern technology is providing competitive options to transmit information at decreasing costs. The Internet is already experiencing explosive growth, but it is an obscure path in the primeval forest compared with the reticulated arteries, including byways for specialized commercial purposes, and thoroughfares for video and multimedia communication, that will soon be established. Simply by protecting the right of information transmission, the property-based vision of the First Amendment provides greater assurance than ever before that those with useful information will find a path to convey it.

\section{ThE MADISONIAN FIRST AMENDMENT}

The advocates of free expression in seventeenth- and eighteenth-century England were of two kinds: those who defended free speech as an instrument to some collective good, and those who defended it as a natural property right of the individual that was an end in itself. The former defense is familiar to American students of the First Amendment because it was the forerunner of current views that defend freedom of speech as a means of achieving self-governance. For instance, Areopagitica's famous plea for freedom from licensing laws rested not on the proposition that free speech was a right inherent in the individual, but on the view that free speech was a necessary means of discovering divine truth. ${ }^{34}$ Milton argued for freedom from prior restraint because only through the application of the diversity of human intelligence could mankind successfully recover the divine order that had been lost in a fallen world. ${ }^{35}$ For Milton, freedom of speech was an instrument, rather than a goal, and thus his approach to that liberty has an outlook wholly different from an approach centered in individual rights. ${ }^{36}$ In fact, Milton believed

conception of the First Amendment, and, as a result, provided Congress with an unnecessary and potentially dangerous power to interfere with the emerging modern networks of telecommunication.

${ }^{34}$ John Milton, Areopagitica, in Stephen Orgel and Jonathan Goldberg, eds, John Milton 236, 263 (Oxford 1991). Milton opposed licensing laws because they would frustrate this search. Id at 263-64 ("Suffer not these licensing prohibitions to stand at every place of opportunity forbidding and disturbing them that continue seeking, that continue to do our obsequies to the torn body of [Truth,] our martyred saint.").

${ }_{35}$ Id at 240 (He "who kills a man kills a reasonable creature, God's image; but he who destroys a good book kills . . . the image of God, as it were, in the eye.").

${ }^{36}$ See Stanley Fish, Unger and Milton, 1988 Duke L J 975, 979 ("[D]espite surface similarities, Milton's program is finally the antithesis of [ ] liberalism."). Ultimately, all theories that understand the First Amendment as an instrument to the collective good 
that those forms of speech not useful in reaching his goal should be suppressed, ${ }^{37}$ and that once the goal of divine truth was reached, the liberty could be discarded altogether. ${ }^{38}$ As we will see, the self-governance theory of free speech, which like Milton's is only instrumental, affords a similarly contingent liberty. ${ }^{39}$

Relatively forgotten today, as compared with Milton's theories, are ideas from late seventeenth- and eighteenth-century England that foreshadow a property-centered theory of the First Amendment. This is somewhat surprising, since property rights were at the center of the emerging Whig theory of government in England during that period, and it was the Whig paradigm that dramatically influenced the framing of the Constitution. ${ }^{40}$

The seeds of a property-centered First Amendment were blown across the Atlantic in three separate vessels. First, the two English episodes that were most renowned in the colonies as victories for freedom of the press-the termination of licensing laws and the denial of government power to seize written materials under general warrant-were both justified on propertyrights grounds. ${ }^{41}$ Second, the essays on the theory of government most widely read in the colonies saw liberty and property rights as essentially indivisible. ${ }^{42}$ Finally, the most sophisticated

lead to censorship because there is no reason to believe that the actual distribution of information resulting from complete freedom of transmission will lead to a predefined notion of the good.

${ }^{37}$ Thus, Milton did not wish to extend tolerance to Roman Catholics because their writings would not be useful in the search for truth. See Fredrick Seaton Siebert, Freedom of the Press in England 1476-1776 197 (Ilinois 1952).

${ }^{33}$ The freedom of inquiry contemplated by Milton will only last until "we come to beatific vision [of the entire divine Truth of the world]." Milton, Areopagitica at 263 (cited in note 34). See also Fish, 1988 Duke L J at 979 (cited in note 36):

Milton, however, counsels not the managing of difference but its multiplication; and his aim is not to protect difference, in the sacred name of individual rights, but finally to eliminate it. That is why his insistence that we not pitch our tents here, on the campgrounds of any orthodoxy, is qualified by a future hope: "till we come to beatific vision." Beatific vision names that state when all visions will be one and indistinguishable from the vision of deity. Difference then is only a temporary and regrettable condition, but one, paradoxically, that we must take advantage of if we are to transcend it.

39 For a discussion of the manner in which self-governance theories of the First Amendment are being used to favor regulation of speech, see notes 288-96 and accompanying text.

${ }^{40}$ Professor William Mayton is a notable exception to the usual failure to emphasize the role of the Whig printers. See William T. Mayton, The Illegitimacy of the Public Interest Standard at the FCC, 38 Emory L J 715, 720-27 (1989).

41 See notes 46-61 and accompanying text.

42 See notes 62-67 and accompanying text. 
philosophical defense of the Whig theory of government and the primacy of property rights, namely John Locke's Second Treatise on Government, ${ }^{43}$ provided direct theoretical inspiration to James Madison-the drafter of the First Amendment. ${ }^{44}$ Indeed, the echoes of the Second Treatise in Madison's most extensive discussion of the philosophical wellsprings of the First Amendment make it obvious that he adapted Lockean principles to defend freedom of speech on the grounds that it was an aspect of the individual's property right in his information. ${ }^{45}$

A. The Role of Property Notions in the Struggle for a Free Press in England

It should not be surprising that printers played the most prominent role in attacking restrictions on freedom of the press in England and that they relied on arguments drawn from property rights to do so. Printers faced loss of income when the government suppressed the publication of materials they purchased from authors. Printers, as part of the rising middle class, naturally sought to defend their interests and limit the prerogatives of the government. Finally, printers were in a good position to exert political influence over parliament and the judiciary because they owned many of the newspapers of the day. ${ }^{46}$ Printers were in fact intimately involved in the two most important blows struck for a free press in England-the demise of the licensing system, and the termination of general warrants by which the government seized printed material. ${ }^{47}$ The notion of information as property came naturally to printers and played a prominent part in their arguments for freedom-arguments that, unlike

43 John Locke, Two Treatises of Government (Laslett 2d ed 1967) 285.

44 For a discussion of Locke's influence on Madison, see text accompanying notes 6892.

45 See James Madison, Property, Natl Gazette (Mar 27, 1792), reprinted in Robert A. Rutland, et al, eds, 14 The Papers of James Madison 266-68 (Virginia 1983). While both the English Whigs and Madison defended free speech on essentially liberal grounds, and thus rooted the concept of freedom of speech in property rights, I do not argue that they fully comprehended the libertarian consequences of the structure of their arguments. The arguments may have been deployed for limited purposes, such as eliminating licensing laws, see Leonard W. Levy, Legacy of Suppression: Freedom of Speech and Press in Early American History 185 (Belknap 1960) (arguing that concept of free speech at the time of the Framing contemplated only limits on prior restraints), but it is the structure of their conception that is relevant to current debates.

46 See Siebert, Freedom of the Press at 8 (cited in note 37).

47 Id. 
Milton's, actually succeeded in curtailing the government's power to regulate expression.

In 1693 printers made their winning argument against the licensing system. ${ }^{4}$ The system, originated by Henry VIII, required that books bear the imprimatur of a licenser in London before they could be printed. ${ }^{49}$ As such, it was a classic example of "centralized, bureaucratic control." ${ }^{50}$ The Whig printers' attack on the law was grounded in theories of individual economic rights and consumer welfare, as opposed to the theological arguments of Milton. In their successful petition to the House of Lords, they argued against a renewal of the licensing system on the grounds that it "subjects all Learning and true Information to the arbitrary Will and Pleasure of a mercenary, and perhaps ignorant, Licenser; destroys the Properties of Authors in their Copies; and sets up many Monopolies. ${ }^{\text {"5l }}$ These are exactly the same kinds of arguments that were deployed by those defending rights in material property against centralized bureaucratic control. $^{52}$

Seventy years later the printers played an important role in another confrontation concerning the freedom of the press-this time over the government's power to use general warrants to seize books and papers in order to prosecute seditious libel actions. ${ }^{53}$ The printers funded the litigation of John Wilkes, a prominent opposition member of the House of Commons, and his associates, in which they contested the government's power to search their houses for papers that they had used in producing newspapers critical of the government. ${ }^{54}$ At the time, these suits were widely understood to be part of the ongoing crusade for greater freedom for the press. ${ }^{55}$ Indeed, colonial Americans remembered this set of cases as one of the great turning points in

43 Actual victory came in 1694, when the House of Commons failed to renew the Licensing Act. See Sir William Holdsworth, 6 A History of English Law 375 (Methuen 2d ed 1937).

49 Mayton, 38 Emory L J at 721 (cited in note 40).

os Id.

$5115 \mathrm{HL}$ Jour 280 (Mar 8, 1692).

52 See, for example, Adam Smith, 1 An Inquiry into the Nature and Causes of the Wealth of Nations 165 (Chicago 1976) (Edwin Cannan, ed).

63 The Supreme Court has recognized that the history of the struggle over the use of general warrants "is largely a history of conflict between the Crown and the press." Stanford $v$ Texas, 379 US 476, 482 (1965).

is See Stephan Landsman, The Rise of the Contentious Spirit: Adversary Procedure in Eighteenth Century England, 75 Cornell L Rev 497, 585 (1990) (discussing role of printers in litigation).

$\omega$ Id at 584 . 
the struggle for that freedom. ${ }^{56}$ Wilkes and Judge Charles Pratt Camden, who in Entick $v$ Carrington ${ }^{57}$ handed down the most celebrated of the opinions rebuking the government, became heroes of liberty throughout the colonies. ${ }^{58}$

Property notions were again crucial to the printers' victory. In Entick, Judge Camden began his discussion of the legality of the government's searches by reiterating the basic axiom of the Whig theory of government:

The great end, for which men entered into society, was to secure their property. That right is preserved sacred and incommunicable in all instances, where it has not been taken away or abridged by some public law for the good of the whole. ${ }^{59}$

Judge Camden then deployed this contemporary theory of government to overturn the old practices of the Star Chamber as well as the common law opinion of the former Chief Judge Scroggs, which had previously permitted the seizure of written material under a general warrant. ${ }^{60}$ Judge Camden reasoned that while the government could seize stolen goods under a general warrant, it could not search and seize the printed materials of Wilkes's printer associate because the printer had superior title to them:

Papers are the owner's goods and chattels: they are his dearest property; and are so far from enduring a seizure, that they will hardly bear an inspection; and though the eye cannot by the laws of England be guilty of a trespass, yet where private papers are removed and carried away, the secret nature of those goods will be an aggravation of the trespass, and demand more considerable damages in that respect. $^{61}$

${ }^{56}$ See Siebert, Freedom of the Press at 381 (cited in note 37) (observing that these cases destroyed "the last of the arbitrary powers of the executive derived from the Regulation of Printing Acts").

5719 Howell St Trials 1029 (CP 1765).

ss See Akhil Reed Amar, Fourth Amendment First Principles, 107 Harv L Rev 757, 772 n 54 (1994) (noting that "Wilkes and Liberty" became a rallying cry for all those who hated government oppression" and that "Americans across the continent named cities, counties, and even children in honor of Wilkes and the libertarian judge, Lord Camden").

5919 Howell St Trials at 1066.

60 See Eric Schnapper, Unreasonable Searches and Seizures of Papers, 71 Va L Rev 869, 875-84 (1985) (describing English precedent).

61 Entick, 19 Howell St Trials at 1066. For a discussion of the importance of property concepts to the Entick holding, see Samuel A. Alito, Jr., Documents and the Privilege 
Judge Camden, locating the property right at issue in the physical substance of the pages as opposed to the ideas themselves, was not quite as explicit about the relationship between property and information as Madison would be twenty years later. Nevertheless, despite his own sense of the inadequacy of prior legal categories ("the eye cannot by the law of England be guilty of trespass"), Judge Camden believed that the appropriation of the physical matter did not capture the enormity of the wrong in seizing printed material. He stated that damages for the trespass should be increased because disclosure of the information at a time when its owners wished to keep it secret was an injury distinct from the seizure of the physical papers, thus hinting that an individual had a property right in information that he produced as well as in tangible things. In any event, it is clear that the decision in Entick was premised on Camden's understanding of Whig political theory and protection for property that flowed from that theory.

Thus, in two of the most celebrated victories for freedom of the press at the time of the Framing, property notions were intimately connected to the evolution of this new liberty. These famous historical incidents, however, were not the only factors linking the emerging categories of free speech and press with property rights. The Whig tradition was not only the intellectual framework for diminishing government censorship in England, but also the foundation of American political philosophy at the time of the Framing. ${ }^{62}$ In the Whig tradition, freedom of speech and property rights were seen simply as different aspects of an indivisible concept of liberty. For instance, Trenchard and Gordon, the authors of Cato's letters, ${ }^{63}$ equated property and liberty:

By Liberty, I understand the Power which every Man has over his own Actions, and his Right to enjoy the Fruits of his Labour, Art, and Industry, as far as by it he hurts not the Society, or any Members of it, by taking from any Member, or by hindering him from enjoying what he himself enjoys. $^{64}$

Against Self-Incrimination, 48 U Pitt L Rev 27, 34 (1986).

${ }^{2}$ See Laura S. Underkuffler, On Property: An Essay, 100 Yale L J 127, 137-38 (1990).

* Cato's letters have been described as "the most popular, quotable, esteemed source of political ideas in the colonial period." Clinton Rossiter, Seedtime of the Republic 141 (Harcourt, Brace 1953).

4 An Enquiry into the Nature and Extent of Liberty; with its Loveliness and Advan- 
Therefore it is not surprising that even those of the founding generation who did not base their theory of free speech directly on Locke, as Madison would, nevertheless accepted the basic Whig equation of property and what we would currently term civil liberties. ${ }^{65}$ For instance, Joseph Story believed that man has property "in things [and] in actions." time of the Framing it was widely agreed that men's liberty and property rights were one and the same, the right of free speech could be understood as intimately connected to the natural right of property, in the capacious sense in which that concept was then conceived. ${ }^{67}$

B. Madison's Adaptation of Lockean Theory as Justification for the First Amendment

None of the Framers had as sophisticated an understanding of the relation of free speech to property as James Madison. It was Madison who deployed John Locke's theory of property as the touchstone for his conceptualization of the First Amendment. Although many commentators have invoked Madison to support the notion that free speech should be understood principally as an instrument to a collective good, such as promoting deliberation in a democracy, ${ }^{68}$ Madison himself understood freedom of

tages, and the vile Effects of Slavery, in J. Trenchard and T. Gordon, 2 Cato's Letters; or Essays on Liberty, Civil and Religious, And other important Subjects 244, 244-45 (Wilkins 3d ed 1733).

${ }_{65}$ Gordon and Trenchard further suggested that "the Security of Property, and the Freedom of Speech, always go together...." Of Freedom of Speech: That the same is inseparable from Publick Liberty, in J. Trenchard and T. Gordon, 1 Cato's Letters; or Essays on Liberty, Civil and Religious, And other important Subjects 96, 96 (Wilkins 3d ed 1733). For further discussion of the infiuence of Cato's letters, see Jonathan W. Emord, The First Amendment Invalidity of FCC Ownership Regulations, 38 Cath U L Rev 401, 452 (1989).

${ }^{6}$ See, for example, Joseph Story, Natural Law, in James McClellan, Joseph Story and the American Constitution: A Study in Political and Legal Thought 313, 321 (Oklahoma 1971). See also John O. McGinnis, The Partial Republican, $35 \mathrm{Wm} \&$ Mary L Rev 1751, 1763-65 (1994), reviewing Cass R. Sunstein, The Partial Constitution (Harvard 1993) (noting similarity in Federalist and Antifederalist conceptions of natural rights, including property rights).

67 Thus, contrary to those who assert that "the very notion of free speech for citizens had grown out of an older tradition establishing legislative 'speech and debate' immunity from prosecution," see, for example, Akhil Reed Amar, The Bill of Rights as a Constitution, 100 Yale L J 1131, 1151 (1991), the celebrated events and writings discussed here suggest that the concepts of freedom of speech and freedom of press can instead be traced back to an individual-property-rights tradition that emerged in seventeenth- and eighteenth-century England.

cs See, for example, Sunstein, Democracy and the Problem of Free Speech at xvi-xx, 241-52 (cited in note 28). None of these theorists ever confronts Madison's discussion of 
speech as a type of property right inhering in individuals. In an essay on the nature of property and its relation to the individual rights contained in the First Amendment, he declared that every individual has "property in his opinions and the free communication of them." ${ }^{.69}$ Indeed, a careful examination of this essay, the most extended Madison ever wrote on property, shows not only his deep indebtedness to Locke, but also his ability to extrapolate from Locke to create a more subtle defense of freedom of speech than Locke himself ever provided. ${ }^{70}$ Madison stated:

[Property] in its particular application means "that dominion which one man claims and exercises over the external things of the world, in exclusion of every other individual."

In its larger and juster meaning, it embraces every thing to which a man may attach a value and have a right; and which leaves to every one else the like advantage.

In the former sense, a man's land, or merchandize, or money is called his property.

In the latter sense, a man has a property in his opinions and the free communication of them.

He has a property of peculiar value in his religious opinions, and in the profession and practice dictated by them.

He has a property very dear to him in the safety and liberty of his person.

He has an equal property in the free use of his faculties and free choice of the objects on which to employ them.

In a word, as a man is said to have a right to his property, he may be equally said to have a property in his rights.

Government is instituted to protect property of every sort; as well that which lies in the various rights of individu-

property and the First Amendment. For discussion of their theories, see notes 290-96 and accompanying text.

${ }_{69}$ Madison, Property at 266 (cited in note 45). It is clear that in this passage Madison is ruminating on the relation of property and some of the rights contained in the First Amendment. He discusses not only a man's "property in his opinions and the free communication of them" - free speech, but also man's property in his "religious opinions, and in the profession and practice dictated by them"-free exercise. Id.

As far as I can tell, however, no one else has ever quoted this essay in a law review article about the First Amendment. The neglect of this essay is dramatic evidence of the dominance of the two competing First Amendment theories: the idea of the First Amendment as an instrument of collective democratic good, and the idea of the First Amendment as self-expression. For further discussion of these competing theories, see Part IV.

7 Locke did not explicitly include any provision for free press or free speech in his scheme of government. See Siebert, Freedom of the Press at 6 (cited in note 37). 
als, as that which the term particularly expresses. This being the end of government, that alone is a just government, which impartially secures to every man, whatever is his own. ${ }^{71}$

This discussion shows Madison's embrace of Lockean theory in three separate respects. First, Madison's view that man has a property "in the safety and liberty of his person" echoes Locke's declaration that "every Man has a Property in his own Person." Moreover, Locke went on to state that "The Labour of his Body, and the Work of his Hands... are properly his."73 It was a short, but still insightful step for Madison to embrace the proposition that man had a property right in the ideas his person produced; that is, that he had a property right in his opinions. ${ }^{74}$ Indeed, Madison's inference suggests that he had a deep appreciation of Locke's theory of property and its relation to Locke's theory of human autonomy. The latter theory held that an individual owns property by applying his labor to matter ${ }^{75}$ and thus infusing his spirit into nature. ${ }^{76}$ If an individual may own material property by applying his labor, then, a fortiori, in Madison's view, the ideas and information each individual produces can be understood as property. ${ }^{77}$ It is important to note that the

21 Madison, Property at 266 (cited in note 45).

72 Locke, Two Treatises at 305 (cited in note 43).

23 Id at 305-06.

74 The use of the word "opinions" suggests that Madison employed a broad conception of First Amendment freedoms. Opinions can be used to mean not only analyses and descriptions of data but also descriptions of one's emotional state and probable course of conduct. The breadth of Madison's concept of "opinions" is also suggested by Madison's use of the word to encompass religious beliefs. In addition, his discussion of "religious opinions" as a kind of property suggests that Madison saw a close connection between the Free Speech and Free Exercise Clauses.

${ }_{75}$ Even formulating relatively commonplace statements demands some expenditure of energy; our brains must fire hundreds of thousands of neurons. See Pinker, Language Instinct at 317-22 (cited in note 23).

${ }^{76}$ See Andrzej Rapaczynski, Nature and Politics: Liberalism in the Philosophies of Hobbes, Locke, and Rousseau 189 (Cornell 1987). Madison captures this connection between autonomy and property by stating that "as a man is said to have a right to his property, he may be equally said to have a property in his rights." Madison, Property at 266 (cited in note 45 ).

77 One caveat is that one has a right to information only insofar as it was not acquired in violation of the property rights of others. This caveat is implicit in the proviso that one has a property right only so long as one's appropriation "leaves to every one else the like advantage." Madison, Property at 266 (cited in note 45). Stealing someone else's property hardly leaves him the "like advantage." The First Amendment thus does not give a right, for instance, to photocopy books of others, even if such action will disseminate one's own views. For discussion of the relation between copyright and the First Amendment under a property-based theory, see Part II.B. 
breadth of the Madisonian/Lockean conception of ownership permits dominion over a wide range of information produced by an individu$\mathrm{al}^{78}$ including not only ideas in the sense of explanations, descriptions, or claims about the moral or material world, but also commitments to others such as offers and promises. ${ }^{79}$

Madison understood that free speech is a property right because property in its broadest sense "embraces every thing to which a man may attach a value and have a right; and which leaves to every one else the like advantage." ${ }^{800}$ The latter phrase replicates Locke's famous proviso that there is a natural right to acquire property "at least where there is enough, and as good left in common for others. ${ }^{81}$ Whether this proviso is satisfied when an individual takes dominion over material items such as land or other natural resources is often a complicated question. Because there is a limited material supply, one person's use may preclude another's. ${ }^{82}$ It is not surprising that Madison found it relatively self-evident that a person's right to produce ideas and transmit them to whomever he wishes satisfied this proviso. There does not seem to be a limited supply of ideas, and one person's production and transmission of ideas does not deny those opportunities to others. ${ }^{83}$

${ }^{78}$ The most comprehensive defense of understanding all information as property is contained in Lysander Spooner, The Law of Intellectual Property 1, 17-21 reprinted in 3 The Collected Works of Lysander Spooner (M \& S 1971). Spooner brilliantly defends this view against various objections, such as the arguments that ideas cannot be identified and thus cannot be property, id at 57-59, and that ideas cannot belong to two people simultaneously, id at 68-69.

79 The breadth of the information production protected by Lockean theory is important for two reasons. First, it helps explain why the Constitution affords special protection to property rights in information as opposed to material production: commitments and promises are particularly dangerous to rulers. See text accompanying notes 104-09. Second, it ensures that the Lockean theory comports with the broad role that information transmission has played in the evolution of the human species: our information transmission and reception abilities have arisen both to explain the world and to facilitate mutually useful relations of all kinds among members of our species. See generally MicGinnis, Information Transmission (cited in note 23), for discussion of these two functions of information transmission in the evolution of human nature.

85 Madison, Property at 266 (cited in note 45).

81 Locke, Two Treatises at 306 (cited in note 43).

82 For an attempt to sort out these complicated issues, see Robert Nozick, Anarchy, State, and Utopia 174-82 (Basic Books 1974). I discuss them briefly in note 256.

$\approx 3$ Distinguished commentators have followed this common-sense understanding that creating intellectual property always satisfies the Lockean proviso. See, for example, John Stuart Mill, Principles of Political Economy 233 (Longmans, Green 1872). Recently, Professor Gordon challenged this claim, suggesting that creating intellectual property and retaining exclusive rights to it may not satisfy the Lockean proviso under certain conditions. See Wendy J. Gordon, A Property Right in Self-Expression: Equality and Individualism in the Natural Law of Intellectual Property, 102 Yale L J 1533, 1566-70 (1993). 
In this passage, Madison also emphatically reiterates Locke's understanding of the purpose of government. Locke asserted that the preservation of property is the "great and chief end [ ] of Men's uniting into Commonwealths." ${ }^{\text {" }}$ Similarly, Madison states that "[g]overnment is instituted to protect property of every sort," including, in Madison's view, man's property in his "opinions and the free communication of them. ${ }^{885}$ Thus, according to the first principles of the father of the Bill of Rights, free speech is not simply or even principally a means for sustaining a particular form of government; to the contrary, protecting free speech and other property rights is the end for which government is constituted..$^{86}$

Although Madison's discussion of the First Amendment is not very detailed, it also makes the key connection between property in information and the right to transmit information, noting the individual's property interest in the "free communication" of his opinions. ${ }^{87}$ If the government suppressed the means of transmitting information, the individual could not exercise his right of "free communication" and his possession of "opinions" therefore would be less valuable to him. A way of further understanding Madison's insight is to continue his analogy of information to material property. If an individual's rights with respect to his material property were limited to possession, and did not include the right of use and the right of exchange, such property would be far less valuable to him. The right to use material property allows the possessor to enjoy its fruits or income; the right to exchange such property allows not only the possessor but also those who buy his property to enjoy gains from trade ${ }^{88}$ Hence the rights of use and disposition are important wealth-maximizing aspects of an individual's ownership of material property, as well

However, Professor Gordon does not recognize that the First Amendment itself is a reflection of the Lockean natural rights theory of property. Rather, she contrasts natural rights in intellectual property with First Amendment values. Id at 1536-37. For a discussion of why the underlying theory of the First Amendment is generally consistent with that of copyright, see Part II.B.

84 Locke, Two Treatises at 368 (cited in note 43).

85 Madison, Property at 266 (cited in note 45).

${ }_{86}$ See Federalist 10 (Madison), in Clinton Rossiter, ed, The Federalist Papers 77, 78 (Mentor 1961) ("The protection of these faculties [the different and unequal faculties for acquiring property] is the first object of government.").

87 Madison, Property at 266 (cited in note 45).

\& Richard A. Epstein, Property and Necessity, 13 Harv J L \& Pub Policy 2, 3-4 (1990). Gains from trade result from the legal right of the possessor to sell his property to a user who values the property more highly than does the possessor. Id. 
as the essential reason that property rights result in increased wealth for society as a whole.

Similarly, the rights to communicate ideas and information free from interference (what this Article calls transmission rights) increase the value of information to the individual in possession of it. ${ }^{89}$ By exercising his right to transmit information to others, the individual may gain the receipt of money, return information, or increased respect in his community of information receivers. ${ }^{90}$ In this Article, I shall refer to the gains from freedom to transmit as the "use value" of information. I thus distinguish it from what I define as the "retention value" of information that comes from the intellectual property rights, such as copyright, that allow information producers in some cases to alienate information to one person while retaining the exclusive right to alienate it to another. ${ }^{91}$ Because, for reasons discussed below, the government poses a substantial threat to an individual's exploitation of the use value of his information, ${ }^{92}$ Madison was correct to understand the First Amendment as a right of "free communication" that allowed an individual to realize value in information beyond the value he enjoyed by simply possessing it.

For discussion of the importance of social exchange of information, see text accompanying notes $141-46$.

$s_{0}$ Under the Madisonian/Lockean view, recipients of information do not have First Amendment rights because they have not labored to create or transmit the information. Thus, in this theory, the part of First Amendment jurisprudence that is built on the right to receive information has no secure foundations. The classic statement of that faulty jurisprudence is found in Red Lion Broadcasting Co. v FCC, 395 US 367, 390 (1969) ("It is the right of the viewers and listeners, not the right of the broadcasters, which is paramount."). That opinion invokes the self-governance rationale of the First Amendment to support the right of citizens to information. Id. For other criticism of Red Lion and subsequent decisions, see notes $265-68$ and accompanying text.

${ }^{91}$ Thus, in my terminology, "use value" of information includes the value that an individual obtains from one-shot sales of information, as well as from social exchange for return information or status. For a discussion of the relationship between copyright (the regime for protecting retention value), and the First Amendment (the regime for protecting use value), see Part II.B. In addition, there is another kind of value of information, besides use value and retention value-I call this "possession value." Possession value is the value produced by the noncommunicative beneficial actions that an individual can take on the basis of his own information.

For reasons discussed below, see text accompanying notes $141-46$, I think this is a useful way to distinguish types of information. Individuals have had use value in information since at least the time our ancestors formulated sentences. Retention value, on the other hand, requires at least some rudimentary mechanisms of contract; the maximization of such value requires mechanisms such as copyright that have been developed only since the Renaissance.

$\$ 2$ See text accompanying notes 102-12. 
Madison's argument for the First Amendment is thus rooted in Locke's theory of natural property rights. From some of his other writings, we know that Madison saw another important similarity between free speech and rights in material property: he believed that the social welfare gains from protecting natural rights in information transmission were similar to those gains from protecting natural rights in material property. Like Adam Smith, Madison and other Framers believed that rights in material goods create prosperity and, indeed, ensure the progress of civilized society. ${ }^{93}$ Analogously, Madison believed that property rights in opinions (called the freedom of speech) lead to the discovery of truth, as false ideas are refuted and replaced..$^{94}$ For instance, Madison suggests that it is "to the press alone, chequered as it is with abuses, the world is indebted for all the triumphs which have been gained by reason and humanity over error and oppression." dom of speech has the same consequences as the exercise of other property rights, in that it helps sustain a beneficial, decentralized civil order outside the control of the state. ${ }^{96}$

We should not be surprised that Madison emphasizes that the exercise of natural rights of information transmission has beneficial consequences. Like all great liberal theorists, Madison was a compatibilist in his deployment of deontological and consequentialist theories. ${ }^{97}$ Because of the human capacity for self-delusion and error, almost all political arguments, even when

${ }^{93}$ See, for example, James Madison, Note to His Speech on the Right of Suffrage, in Department of State, Documentary History of the Constitution of the United States of America 1786-1870 Appendix at 440,441 (1905) ("In civilized communities, property . . is an essential object of the laws, which encourage[s] industry by securing the enjoyment of its fruits."); Gouverneur Morris, Political Enquiries, 1776: An Essay by Gouverneur Morris, in Willi Paul Adams, "The Spirit of Commerce Requires that Property Be Secured": Gouverneur Morris and the American Revolution, 21 Amerikastudien 327, 331 (1976) ("The most rapid advances in the State of Society are produced by Commerce. ... [Commerce] requires not only the perfect Security of Property but perfect good faith. ... It requires also that every Citizen have the Right freely to use his Property. ${ }^{n}$ ).

${ }_{94}$ See, for example, James Madison, Address of the General Assembly to the People of the Commonwealth of Virginia, in Gaillard Hunt, ed, 6 The Writings of James Madison 332, 337 (Putnam 1906) ("By subjecting the truth of opinion to [ ] regulation, fine, and imprisonment, to be inflicted by those who are of a different opinion, the free range of the human mind is injuriously restrained.").

95 James Madison, Report on the Resolutions, in Gaillard Hunt, ed, 6 The Writings of James Madison 341, 389 (Putnam 1906).

96 As I argue in Part III, computer nets facilitate that decentralized civil order today.

${ }^{97}$ See Randy E. Barnett, Foreword: Of Chickens and Eggs-The Compatibility of Moral Rights and Consequentialist Analyses, 12 Harv J L \& Pub Policy 611, 619-20 (1989) (discussing classical liberal political theorists' compatibilism). 
they are rooted in natural rights, also appeal to the social benefits of rights. ${ }^{98}$ The convergence of natural rights intuition and a rough utilitarian calculus strengthens our confidence in the results reached by our political and moral theory. ${ }^{99}$

Nevertheless, the starting points of a jurisprudence often dramatically affect its course of development. As we shall see, a natural rights jurisprudence of free speech will, over time, look very different from a jurisprudence that starts with the understanding that free speech is an instrument to a collective good, because the instrumental view is inclined to revise liberties as circumstances change. ${ }^{100}$ Moreover, the social benefit Madison discovers in the exercise of speech rights is much broader than Meiklejohn's goal of collective self-governance. To see increased knowledge as the end of free speech is to embrace an extremely broad and diffuse goal. Characteristically for an Enlightenment thinker, the goal of increasing human knowledge is all-encompassing: nothing human is alien to it. ${ }^{101}$

\section{RECONCEPTUALIZING THE FIRST AMENDMENT}

In light of Madison's understanding of the nature of free speech, how shall we reorient our understanding of the First Amendment in the constitutional order? If we regard the First Amendment as prohibiting government interference with the individual's right to transmit information and realize its use value, we need to inquire into the fit between the First Amendment and other constitutional provisions that relate to property rights in material goods and in information. For instance, why did the Constitution provide, through the First Amendment, far more stringent protections for the use value of information than it provided, through the Fifth Amendment, for the bundle of rights that attach to material property? How is a property-centered

9s Id at 615-16.

$\Leftrightarrow$ Id.

103 For discussion of these differences, see text accompanying notes 290-96.

101 Neither the self-governance theory nor the self-expression theory of the First Amendment justify a scope of free inquiry as broad as the property-based theory. Many matters interesting and important to individuals are not amenable to redress by government, and thus fall outside the self-governance rationale. See Oliver Goldsmith, The Traveller, reprinted in Arthur Friedman, ed, 4 Collected Works of Oliver Goldsmith 248, 269 (Clarendon 1966) ("How small, of all that human hearts endure, / That part which laws or kings can cause or cure."). Moreover, the market is itself an indispensable way of discovering the wants and needs of other individuals, but the self-expression theory conventionally excepts market information from its ambit. See text accompanying notes 322-27. 
view of the First Amendment consistent with the Copyright Clause, which provides Congress with an independent power to protect what I have defined as the retention value of information? The answers to these questions, developed in Parts A and B below, actually confirm the coherence of the property-based view of the First Amendment and its consonance with the rest of the Constitution.

Once it is understood that the property-centered vision is coherent and consistent with the original animating principles of the Constitution, there remains the question of what it would mean in practice. What might a property-centered First Amendment jurisprudence look like? Given that the press and analogous mass media use all sorts of privately owned material property to transmit information, how would a property-based jurisprudence protect such property against burdensome government regulation? Part $\mathrm{C}$ attempts to sketch the contours of a First Amendment jurisprudence that protects the individual's use value of his information.

A. The Constitution's Special Protection for the Use Value of Information

The Constitution affords more substantial protection to free speech rights than to most other rights related to material property. However, differing standards of protection for different rights are not inconsistent with understanding free speech as rooted in protecting an individual's use value in his information. Republican theory at the time of the Framing was realistic enough to understand that no structure of government could protect all natural rights perfectly, because any branch of government with sufficient unity and power to achieve perfect enforcement would in the end degenerate into tyranny. ${ }^{102}$ Since complete and perfect enforcement was not possible, it was rational to provide special protection for those rights most threatened by rulers.

102 For a fuller discussion of the Framers' realism about the ability of the state to protect all natural rights, see McGinnis, $35 \mathrm{Wm} \&$ Mary L Rev at 1773-81 (cited in note 66). One criticism, therefore, of a libertarian regime like the one Richard Epstein envisions is that mandating judicial protection for all natural rights invests excessive power in a single government institution. See Richard A. Epstein, Takings: Private Property and the Power of Eminent Domain (Harvard 1985) (suggesting that the judiciary protect a wide range of economic liberties). 
The right to transmit information, either unassisted or through the use of material property-the rights of free speech and free press, respectively-is an obvious candidate for a natural right that requires special protection. ${ }^{103}$ Unlike the exercise of other property rights, the right to publish ideas and transmit promises and commitments to others can directly and immediately threaten the positions of the rulers of society, particularly in a republican system where the rulers' positions are dependent on the opinions of the ruled. ${ }^{104}$ Indeed, what distinguishes all the

${ }^{103}$ Some have argued that the Framers' failure to apply the First Amendment to the states suggests that the Amendment was not intended to protect individual rights, but rather a right of the majority to control the federal government. See, for example, Amar, 100 Yale $L \mathrm{~J}$ at 1147-48 (cited in note 67). I find this inference unwarranted. Madison, in fact, proposed that the First Amendment be applied to the states, see James Madison, Statement in Congress, in Bernard Schwartz, 5 The Roots of The Bill of Rights 1023, 1027 (Chelsea House 1980) ("No State shall violate the equal rights of conscience, or the freedom of the press, or the trial by jury in criminal cases."), but the final version applied only to the federal government. The object of protecting transmission rights against interference by state governments, however, could be accomplished as effectively by state constitutions as by the federal constitution, and many state constitutions at the time of the Framing protected the freedom of speech, the freedom of the press, or both. See, for example, Virginia Declaration of Rights (1776), reprinted in Bernard Schwartz, 2 The Roots of The Bill of Rights 234, 235 (Chelsea House 1980) ("[F]reedom of the Press is one of the greatest bulwarks of liberty."). Imposing a federal restriction on the states thus may have seemed relatively unimportant. For a fuller discussion of state constitutional protections of free speech and free press at the time of the Framing, see Jonathan W. Emord, Freedom, Technology, and the First Amendment 68-70 (Pacific Research Institute for Public Policy 1991).

Moreover, political theory at the time of the Framing was concerned with preventing the federal government from becoming powerful enough to degenerate into tyranny. Theorists thus sought to maximize the long-run protection for natural rights. See McGinnis, 35 Wm \& Mary L Rev at 1762-63 (cited in note 66). The states were one of the principal restraints on the federal government. See Michael W. McConnell, Federalism: Evaluating the Founders' Design, 54 U Chi L Rev 1484, 1504-05 (1987), reviewing Raoul Berger, Federalism: The Founders' Design (Oklahoma 1987) (One of the principal purposes of federalism was to diffuse power in the interest of constraining the federal government.). Thus, the Framers had an affirmative reason based in their political theory to conclude that the loss of state autonomy occasioned by giving additional powers to the federal judiciary outweighed the benefits of providing citizens additional rights against the states-particularly when the states were showing every sign of granting them anyway.

Another difficulty with Professor Amar's inference is that the Bill of Rights contains other provisions, such as the Takings Clause, that are intended to protect natural rights, and again applies these provisions only to the federal government.

10.4 For the same reason that information transmission rights are feared by rulers, they are particularly useful to citizens. See, for example, Madison, Report on the Resolutions at 397 (cited in note 95) ("The ... efficacy of this right [of electing representatives] depends on the knowledge of the comparative merits and demerits of the candidates for public trust, and on the equal freedom, consequently, of examining and discussing these merits and demerits of the candidates respectively."). These rights allow citizens to discover through discussion whether there exists a critical mass of opposition to the rulers' decisions and then to develop majorities to restrain a self-interested legislature 
individual rights mentioned in the First Amendment-free speech, free press, free exercise of religion, and free assembly-from many of the others mentioned in the Bill of Rights is that the exercise of First Amendment rights poses an imminent danger to those in control of the government. ${ }^{105}$ The history known to the Framers revealed that a speech against the governor, a newspaper article exposing corruption, an impromptu assembly of those with festering grievances, or a religious crusade all could oust a set of rulers much faster than the accumulation of material wealth. ${ }^{106}$ Thus, even if the Framers believed that individuals' rights in their information were neither more natural to man nor more beneficial to society than rights relating to material property, they could still have rationally bestowed more protection on information transmission rights precisely because such rights are more likely to be suppressed by those seeking to maintain political power. ${ }^{107}$

and executive. Thus Professor Amar is right to see the First Amendment as facilitating majoritarian control. See Amar, 100 Yale L J at 1147 (cited in note 67). It does not, however, necessarily follow that because the First Amendment has these consequences, free speech is protected to promote majority rule rather than on account of its status as a natural right. Nor is there any fundamental dichotomy, as Professor Amar seems to imply, between viewing free speech as a right of majoritarian control or of minority opposition. Id. Majorities do not come ready-made: transmission rights are necessary for citizens to discover that they are in a majority on an issue and, if they are not, to form a coalition with other groups on a range of issues so they can forge a majority. Moreover, because public opinion changes, today's minority may be tomorrow's majority. Transmission rights for minorities thus enable smoother transitions to new majorities: they provide an advance warning system of democratic change. Republican theory at the time of the Framing was intensely concerned with political stability, see McGinnis, $35 \mathrm{Wm} \&$ Mary L Rev at 1774-77 (cited in note 66), and the Framers' concern with minority rights as well as majority rights can be understood in that context.

${ }_{105}$ One material good that could immediately threaten government was armaments. Thus, it is wholly consistent with the theory of the First Amendment offered here that the Constitution, through the Second Amendment, gave special protection to citizens' right to possess arms. See Nelson Lund, The Second Amendment, Political Liberty, and the Right to Self-Preservation, 39 Ala L Rev 103, 113-21 (1987) (discussing the analogy between the First and Second Amendments).

If government poses a greater threat to free speech than to most material property, it is possible to agree with Ronald Coase that economic freedoms are as important as freedom of speech, see R.H. Coase, The Market for Goods and the Market for Ideas, 64 Am Econ Rev 384, 385-86 (1974), but still conclude that in a world where it is impossible to protect all rights perfectly, the judiciary should give particular protection to speech rights.

${ }^{106}$ For a discussion of the manner in which the dispersion of ideas overthrows governments, see Robert Darnton, The Forbidden Best-Sellers of Pre-Revolutionary France 15997 (Norton 1995) (suggesting that literature could facilitate opposition to a regime by crystallizing subversive attitudes forming in different sectors of society).

107 Given the heavy government regulation of material property rights since the New Deal, it may be open to doubt whether the state now poses a greater threat to the rights of information transmission than to the rights of material production. The Framers may 
Although the primary reason for providing special protection for the use value of information lies in our suspicion of rulers, the text of the First Amendment does not distinguish between political speech and other forms of speech. Even if the rulers were a threat to only political speech, though, the constitutional design would not be endangered by protecting a broader range of information: the point of Locke's and Madison's scheme of government was to protect as much property as possible. ${ }^{108}$ In any event, the rationale for protecting information transmission cannot easily be limited to the transmission of overtly political information. First, it is difficult to fashion a distinction between speech that may be threatening to rulers and speech that is not. ${ }^{109}$ Second, pure political speech often has to be mixed with

have mistakenly calculated the difference in the respective dangers. While they were all too familiar with the suppression of speech by the British and other rulers, they did not foresee the modern welfare state, with its pervasive rent seeking, which has become an instrument for concentrated interest groups to expropriate the wealth of the less well organized. For a discussion of this failure of foresight, see Frank H. Easterbrook, The State of Madison's Vision of the State: A Public Choice Perspective, 107 Harv L Rev 1328, 1333-39 (1994). Before confessing error for the Framers, though, we should remember that our confidence that the state will not act against our information transmission rights is largely a consequence of the First Amendment itself. The free speech principle is so thoroughly intermixed with American culture that much information transmission would long remain inviolable even if the First Amendment disappeared tomorrow.

10s The creation and monitoring of protected and unprotected categories of information would be costly. Thus, once it has been decided to provide constitutional protection to information property, there is less reason to make refined subdivisions of the category. Moreover, refusing to protect nonpolitical speech because we cannot find a specific rationale to justify the broad sweep of the language of the First Amendment misses the point that the rationale of the Constitution as a whole was to give as much protection to natural rights as possible. See text accompanying notes $84-86$. Thus, I cannot agree with Robert Bork's view that absent some special justification for protecting other kinds of speech, only political speech was protected by the First Amendment. See Bork, 47 Ind L J at 27 (cited in note 14). This view rests expressly on the premise that the Madisonian system "assumes that in wide areas of life majorities are entitled to rule for no better reason [than] that they are majorities." Id at 2. To the contrary, as we have seen, Madison believed that the protection of natural rights, rather than the promotion of democracy, was the end of government. Madison actually was quite concerned that "[t]here is no maxim ... which is more liable to be misapplied,... than the current one that the interest of the majority is the political standard of right and wrong." See Letter from James Madison to James Monroe (Oct 5, 1786), in Gaillard Hunt, ed, 2 The Writings of James Madison 272, 273 (Putnam 1901).

100 Artistic speech, even of a very subtle kind, can be a threat to political regimes, as the regimes themselves understand. For instance, Michael Chekhov, the great acting theorist, was prevented from directing plays in the Soviet Union because his actors were performing in too spiritual a manner. See Mel Gordon, Introduction, in Michael Chekhov, On the Technique of Acting xxi (HarperCollins 1991).

It is also hard to draw a bright line between commercial speech and political speech. On the one hand, speakers often engage in indisputably political speech for profit, see Alex Kozinski and Stuart Banner, Who's Afraid of Commercial Speech?, 76 Va L Rev 627, 
other forms of speech in order to appeal to a widespread audience and thus create leverage against rulers. This is obviously true of artistic speech; abstract political arguments often have to be interwoven into stories before they resonate with the public. Commercial speech in the form of advertisements is also often necessary to support the publication of political speech, ${ }^{110}$ and thus differential restrictions on commercial speech will affect the ability to disseminate political speech. ${ }^{111}$ Finally, because the distinctions between political, artistic, and commercial speech are quite subtle, the right to fashion these distinctions should be denied the state. After all, the Framers rightly viewed the state as the source of political suppression in the first place. ${ }^{112}$

Accordingly, we should not be surprised that in three separate respects the First Amendment has been more properly construed to afford more protection for the use value of information than the Takings Clause affords for material property. ${ }^{113}$ First, the First Amendment expressly prevents the government from expropriating an individual's use value in his information, while the Takings Clause allows the government to expropriate the use

637 (1990), and, on the other hand, indisputably commercial speech can have deep political objectives. Consider, for instance, a journalist who abandons writing to enter the telecommunications business, in part because he wants to promote a vision of a decentralized, communication-rich society by assembling and advertising a communications network.

110 Indeed, as a historical matter, the development of a free press and a commercial press were inextricably linked at the time of the Framing. See Verner W. Crane, Introduction, in Verner W. Crane, ed, Benjamin Franklin's Letters to the Press 1758-1775 xvi (North Carolina 1950) ("It was a commercial age, and produced a commercial press ....").

"11 Restricting legal advertisements, for instance, may restrict speech about lawyers and legal reform. A periodical would lose access to the class of advertisers that would most wish to advertise in its magazine.

112 Compare Richard A. Posner, Free Speech in an Economic Perspective, 20 Suffolk U L Rev 1, 10 (1986) ("[T] speech, once the purpose of protecting political speech is understood to be the preservation of political competition.").

${ }_{113}$ These three respects can be defined by reference to the three concepts in the Takings Clause underlined here: "[N]or shall private property be taken for public use, without just compensation." US Const, Amend V (emphasis added). First, the Takings Clause permits the government to appropriate property if it provides just compensation. The First Amendment does not permit the government to appropriate the use value of information even with just compensation. See text accompanying notes 114-17. Second, the Fifth Amendment, at least as currently interpreted, does not apply to all material property that might be considered property under a natural rights theory. The First Amendment includes the use value of almost all information within its ambit. See text accompanying notes 118-20. Finally, the Fifth Amendment permits, even without compensation, a substantial amount of regulation that does not amount to a taking, whereas the First Amendment narrowly limits regulation of the use value of information. See Part II.C. 
value of material property so long as the individual receives just compensation. This difference in the constitutional protection for information transmission rights and material property rights can be understood in terms of Calabresi and Melamed's well known distinction between property and liability rules. ${ }^{114}$ Property rules permit transfer of an individual right only through negotiation and agreement; liability rules permit involuntary transfers so long as compensation is paid. ${ }^{115}$ The First Amendment provides individuals with a property right against the government's interference with transmission of information: the government does not have a right to stop you from speaking even it pays you for your lost opportunity. The Fifth Amendment, however, provides individuals with only a liability right against government interference with their material property: the government can take your property so long as it provides you with just compensation. ${ }^{116}$ Thus, in the terms of Calabresi and Melamed, the First Amendment is a property rule, while the Fifth Amendment is a liability rule. ${ }^{117}$

114 See Guido Calabresi and A. Douglas Melamed, Property Rules, Liability Rules, and Inalienability: One View of the Cathedral, 85 Harv L Rev 1089, 1105-10 (1972).

15s Id at 1105-06.

116 Id at 1106-08 (discussing the Fifth Amendment as a liability rule).

117 Calabresi and Melamed argue that the government is given an eminent domain power because in some situations, due to transaction costs, collective decisions about the value of property will be more efficient than individual negotiations. Id at 1106-07. Insofar as we believe that the government is likely to be guided by motives other than efficiency, this justification will be less persuasive.

But even if there were no more reason to be suspicious of the rulers' motives in regulating information transmission rights than in regulating material property rights, there would be two subsidiary reasons why the Fifth Amendment's liability rule would not have been well adapted to information transmission rights. First, the holdout problems that are a primary justification for takings by the state are not generally present in the context of the use value of information. See Carol Rose, The Comedy of the Commons: Custom, Commerce, and Inherently Public Property, 53 U Chi L Rev 711, 749-50 (1986) (discussing the holdout rationale that justifies government taking). Second, as discussed in the text accompanying notes 144-49, the use value of information is often realized through the receipt of return information, through other property exchanges the transmission facilitates, or through slight changes in the status or reputation of the information transmitter. Assessing the use value of such information ex ante would often be more difficult than assessing the value of material property. In light of these difficulties, the "just compensation" provision would not be a workable way of compensating individuals for the information that the government suppressed.

Of course, these differences between the use values of information and material property are differences on average. For some material property, holdout problems are unlikely, and for some material property, the calculation of value will likely prove difficult. But the Framers were practical thinkers who understood that the Constitution had to draw clear distinctions capable of fairly mechanical application even if these distinctions did not capture the complexity of each individual situation. See Douglas W. Kmiec and John O. McGinnis, The Contract Clause: A Return to the Original Understanding, 14 
Second, the First Amendment differs from the Fifth in the comprehensiveness of its definition of the property it protects. The First Amendment protects transmission rights in a very broad range of information-almost everything that could conceivably have use value to an individual. Moreover, the information for which transmission rights will be protected is defined constitutionally and not with reference to state or federal law. On the other hand, the Fifth Amendment, at least as currently interpreted, does not protect all entitlements that would be property in Madison's or Locke's sense. ${ }^{118}$ Furthermore, the judiciary substantially defers to existing law to decide whether there is a property entitlement, thus permitting the state a substantial measure of authority over property rights that it does not enjoy with respect to information transmission rights. ${ }^{19}$ Although it is not clear that the Takings Clause was intended to be quite as narrow a limitation as it has become under current law, ${ }^{120}$ the greater breadth of the First Amendment, like the more stringent nature of its protections, may be justified on the view that rulers have a greater motivation to interfere with the transmission of information than with material property rights. Rulers thus should be given less discretion to choose in advance the category of information the transmission of which will be protected.

Finally, as discussed below, the Fifth Amendment permits substantial regulation of material property without compensation, whereas the First Amendment permits regulation of information for very narrow reasons consistent with natural rights theory. ${ }^{121}$ This difference also reflects the greater concern about the dangers of government regulation of the use value of information.

Hastings Const L Q 525, 528 (1987) (arguing that the Contract Clause protected vested rights only because that limitation permitted more mechanical judicial application).

118 For a discussion of the way in which current Takings Clause jurisprudence fails to protect a full range of entitlements that would have been protected at common law, see Wesley J. Liebeler and Armen Alchian, Constitutional Baselines by Virtual Contract: A General Theory and its Application to Regulatory Takings, 3 S Ct Econ Rev 153, 154-55 (1993).

119 See Lucas v South Carolina Coastal Council, 112 S Ct 2886, 2900-01 (1992) (looking to state law to define the interests protected by the Takings Clause).

${ }_{120}$ For an argument for protecting a broader spectrum of entitlements under the Takings Clause, see Douglas W. Kmiec, The Original Understanding of the Taking Clause is Neither Weak nor Obtuse, 88 Colum L Rev 1630 (1988). But see William Michael Treanor, The Original Understanding of the Takings Clause and the Political Process, 95 Colum L Rev 782, 796-98 (1995) (stating that Takings Clause was originally intended to prohibit only physical takings of property).

121 See text accompanying notes 151-71. 
B. The Underlying Coherence of the First Amendment and the Copyright Clause

Contrary to the views of some scholars, ${ }^{122}$ there is no fundamental tension between the First Amendment and Congress's constitutional authority to provide the security of copyright protection to some information producers. Instead, both provisions stem from the Framers' belief in the individual's natural property right in his information: that right will be secure only if both the right of transmission and the right of retention are protected. The First Amendment and the Copyright Clause ${ }^{123}$ in fact form a coherent scheme to maximize effective protection for producers of information, in the broadest sense, against threats of state and private depredation, respectively. As discussed above, the First Amendment prevents the government from reducing the use value of property in information by interfering with its transmission, because such value is most dangerous to rulers and is, therefore, most threatened by government. On the other hand, the Copyright Clause authorizes Congress to prevent other citizens from stealing one's property in information, because retention value is threatened more by acts of private theft than by government expropriation. ${ }^{124}$ Only when both the use value and retention value of information are protected is the individual's entire natural right to his property in information secured.

Understanding the interaction of the First Amendment and the Copyright Clause as protecting informational property rights in this way is in fact consistent with the Constitution's architecture: maximizing the protection for natural rights in an imperfect world was its principal objective. ${ }^{125}$ Indeed, a review of the

${ }^{122}$ See Diane Leenheer Zimmerman, Information as Speech, Information as Goods: Some Thoughts on Marketplaces and the Bill of Rights, 33 Wm \& Mary L Rev 665, 674-85 (1992) (suggesting that there is a substantial tension that was unrecognized at the time of the Framing between the First Amendment's view of information as a public good and copyright's treatment of information as a private good).

${ }_{123}$ US Const, Art I, § 8, cl 8.

${ }^{124}$ I define "use value" and "retention value" in Part I. See note 91 and accompanying text.

${ }_{125}$ Other constitutional provisions also reflect this underiying goal. For instance, Professor Amar suggests that the reasonableness requirement for searches in the Fourth Amendment should be interpreted so as to maximize protection of natural rights from the related dangers of private violence (crime) and governmental intrusiveness. See Amar, 107 Harv L Rev at 793 (cited in note 58). Too restrictive a view of reasonableness will lead to substantial increases in private violence because government will have difficulty combatting crime; too lenient a view will lead to a substantial increase in government intrusions because government will have the freedom to carry out searches that have little effect on crime. See also McGinnis, $35 \mathrm{Wm} \&$ Mary L Rev at 1762-67 (cited in note 
Copyright Clause confirms that, like the First Amendment, it was intended to protect an aspect of the individual's natural property right in his information. The text of the Clause reads as if it were protecting a natural right, but protecting it only to the extent that enforcement through statute would redound to society's benefit. The Clause provides Congress the authority "[t]o promote the Progress of Science and useful Arts, by securing for limited Times to Authors and Inventors the exclusive Right to their respective Writings and Discoveries." use of the term "securing," rather than a term like "granting," suggests that the authors had a natural right to this property, which the government could then protect through copyright law. ${ }^{127}$

The natural rights roots of the Copyright Clause grow even clearer when one looks to related documents from the time of the Framing. Many of the state copyright laws of the time were even more explicit than the Copyright Clause in their assertion that copyright was designed to protect the natural property rights of authors in their creation. For instance, New Hampshire provided:

As the improvement of Knowledge, the progress of Civilization, and the advancement of Human Happiness, greatly depend on the efforts of learned and ingenious persons in the various Arts and Sciences; as the principal encouragement such persons can have to make great and beneficial exertions of this Nature must consist in the legal security of the fruits of their Study and Industry to themselves; and as such security is one of the natural rights of all men, there being no property more peculiarly a man's own than that which is produced by the labor of his mind. ${ }^{128}$

The echo of Lockean natural rights ideas is both striking and characteristic of many of the early state statutes. ${ }^{129}$ The histori-

66) (suggesting that the Constitution was generally designed to maximize the protections of rights against the twin dangers of private deprivation and state oppression).

${ }_{126}$ US Const, Art I, \& 8, cl 8. The linking of writings and inventions, in fact, suggests that the Framers understood that information could be classified as property.

${ }^{127}$ See Dale A. Nance, Foreword: Owning Ideas, 13 Harv J L \& Pub Policy 757, 763 (1990). But see Wheaton v Peters, 33 US ( 8 Pet) 591, 660-61 (1834) (rejecting this interpretation of the word "secured").

${ }^{123}$ See Act for the Encouragement of Literature (1783), reprinted in 4 Laws of New Hampshire 521 (emphasis added).

${ }_{129}$ Other state copyright statutes sounding in natural property rights are gathered in Alfred C. Yen, Restoring the Natural Law: Copyright as Labor and Possession, 51 Ohio St L J 517, 529 n 79 (1990). 
cal record also suggests that the Framers included a federal copyright provision not because they disagreed with the natural rights theory that animated such state laws but because they feared that variations in state laws and the difficulty of their extraterritorial enforcement would not sufficiently protect these rights. ${ }^{130}$

Moreover, Madison was instrumental in drafting the Copyright Clause as well as the First Amendment. ${ }^{131}$ Defending the Clause in The Federalist Papers, he observed that:

The utility of [the Copyright Clause] will scarcely be questioned. The copyright of authors has been solemnly adjudged in Great Britain to be a right of common law. The right to useful inventions seems with equal reason to belong to the inventors. The public good fully coincides in both cases with the claims of individuals. ${ }^{132}$

The solemn adjudication that Madison understood to have acknowledged copyright as part of English common law was Millar $v$ Taylor, decided in $1769 .{ }^{133}$ That case in turn rested on a theory of natural property rights. ${ }^{134}$ Indeed the judges who decided it were heavily influenced by the same kind of Lockean theories that Madison himself applied to create a property-centered theory of free speech. ${ }^{135}$ The Copyright Clause and the First Amend-

${ }^{139}$ Joseph Story, 3 Commentaries on the Constitution of the United States $\$ 1147$ at 48-49 (Da Capo 1970) (noting that in the absence of federal protection, authors "would have been subjected to the varying laws and systems of the different states on this subject, which would impair, and might even destroy the value of their rights"). See also Federalist 43 (Madison), in Rossiter, ed, The Federalist Papers at 271-72 (cited in note 86) (noting that the states could not make "effectual provision" for copyright).

${ }_{131}$ See Lyman Ray Patterson, Copyright in Historical Perspective 192-94 (Vanderbilt 1968) (discussing Madison's role in proposing copyright protection at the Constitutional Convention).

${ }^{1 \leqslant 2}$ Federalist 43 (Madison), in Rossiter, ed, Federalist Papers at $271-72$ (cited in note 86).

13998 Eng Rep 201 (KB 1769). Madison may also have been influenced in his view of English law by Blackstone. See William M. Blackstone, 2 Commentaries $* 405-06$ (inferring copyright protection at common law).

134 See Patterson, Copyright in Historical Perspective at 171 (cited in note 131).

135 Lockean property-rights theory in fact influenced decisions in favor of a common law copyright in England. See Zimmerman, $33 \mathrm{Wm} \&$ Mary L Rev at 689-92 (cited in note 122).

A few years later the House of Lords held that English authors no longer had a common law copyright. Donaldson v Beckett, 98 Eng Rep 257, 262 (KB 1774). This case did not deny, however, that authors originally had such a natural common law right, but merely held that it had been superseded by the Statute of Anne of 1709. See Patterson, Copyright in Historical Perspective at 174-76 (cited in note 131) (describing Donaldson's analysis of common law right). In Federalist 43, Madison was referring to Millar despite 
ment flow from the same philosophical fount as well as from the same author.

Unlike the First Amendment, however, the Copyright Clause provides protection to a limited subset of information. For instance, the Clause itself requires copyrightable work to be produced by "authors," and the Supreme Court has recently concluded that this concept of authorship requires a spark of originality. ${ }^{136}$ Moreover, the Clause does not provide automatic copyright protection to all information within its scope. Instead, it authorizes Congress to protect retention rights in categories of information that Congress may itself define. Congress has exercised this discretion to restrict the ambit of copyrightable material by codifying a variety of limitations, such as the idea-expression dichotomy and the fair use doctrine. ${ }^{137}$

Nevertheless, the limitation in the scope of copyright is entirely consistent with viewing the Copyright Clause as protecting a natural right of information property. It was an axiom of Locke's political theory that natural rights may be protected less than comprehensively in civil society: greater security for rights is sacrificed for their breadth. ${ }^{138}$ Decisions as to how much society will invest in the mechanisms for protecting various natural rights in a world where their enforcement is costly depend, at least to some extent, on the utility of protecting them. ${ }^{139}$

the intervening decision in Donaldson. See Yen, 51 Ohio St L J at 529 (cited in note 129).

${ }_{136}$ Feist Publications, Inc. $v$ Rural Telephone Service Co., 499 US 340, 345 (1991). This construction goes back at least to the nineteenth century. See Burrow-Giles Lithographic Co. $v$ Sarony, 111 US 53, 59-60 (1884). For a discussion of Feist Publications, see Marci A. Hamilton, Justice O'Connor's Opinion in Feist Publications, Inc. v. Rural Telephone Service Co.: An Uncommon Though Characteristic Approach, 38 J Copyright Soc'y 83, 8690 (1990).

${ }^{137}$ See 17 USC § 102(b) (1988 \& Supp 1993) (denying protection to ideas); 17 USC § 117 (1988 \& Supp 1993) (permitting fair use). The idea-expression dichotomy and the fair use doctrine were initially judge-made rules, but were not repudiated by Congress, and were eventually codified.

${ }^{138}$ See Barbara Friedman, Note, From Deontology to Dialogue: The Cultural Consequences of Copyright, 13 Cardozo Arts \& Enter L J 157, 162 (1994) (discussing this bargain of the social contract in the context of copyright). For further discussion of this proposition, see Philip A. Hamburger, Natural Rights, Natural Law, and American Constitutions, 102 Yale L J 907-44 (1993); McGinnis, 35 Wm \& Mary L Rev at 1779-80 (cited in note 66 ).

${ }_{139}$ The degree to which natural rights should be enforced by government necessarily requires a utilitarian calculus, because protecting the exercise of some natural rights actually poses threats to others. First, protection requires resources that have to be raised by taxing the exercise of natural rights. Second, enforcement requires establishing governmental power that may ultimately be used to encroach on natural rights. 
Many of the categories of copyright depend on such judgments. For instance, the requirement of originality may usefully screen information to determine whether it can be practically protected against third parties. Without an originality requirement, it would be hard to trace information to its origin and thus hard to discover who owned it. The idea-expression dichotomy is at least in part a response to the problem of setting boundaries among ideas to determine their ownership. ${ }^{140}$ Thus, copyright is properly sensitive to the balance between the benefits of protecting retention value and the costs of enforcement.

Whatever the proper limits of copyrightable information, those limits do not encompass all of the information from which individuals may obtain value. ${ }^{141}$ Individuals realize use value from transmitting information even when they cannot or do not want to preserve retention value for information in their possession. ${ }^{142}$ Indeed, assertions of personal opinions, statements about specific situations in the world, and predictions of future events have long been transmitted without the retention of exclusive rights, in the expectation of receiving return information or gaining increased status. ${ }^{143}$ Those who receive that information in

10 See William M. Landes and Richard A. Posner, An Economic Analysis of Copyright Law, $18 \mathrm{~J}$ Legal Stud 325, 349 (1989) (discussing enforcement costs of sorting out ownership in ideas).

${ }^{141}$ Another indication that copyright does not define the entire scope of information property is that we can easily conceive of legal regimes that would allow individuals to preserve retention rights in what is now not subject to copyright. Information transmitters could contract to permit others to use ideas on the condition that they not be transmitted to third parties; the common law of torts could prevent third parties from interfering with those contracts. See Edmund W. Kitch, Intellectual Property and the Common Law, 78 Va L Rev 293, 297-300 (1992) (discussing how contract and tort can be used to protect information). Of course, monitoring and transaction costs might often make such contracts impracticable. But this only serves to demonstrate that copyright should be understood as an extraordinary enforcement mechanism to protect the retention value of information property where such a right would be particularly valuable, and is not a limit on the scope of information that can be conceived as property. See Wendy J. Gordon, Fair Use as Market Failure: A Structural and Economic Analysis of the Betamax Case and its Predecessors, 82 Colum L Rev 1600, 1612-13 (1982) (copyitight reduces transaction and monitoring costs). Moreover, even current copyright law recognizes that state governments may establish supplementary legal regimes to protect some kinds of noncopyrightable information, such as trade secrets. See 17 USC $\$ 301$ (1988 \& Supp 1993) (copyright does not preempt state law protecting certain categories of information).

142 Information may not have sufficient retention value to be worth protecting even by contract. See note 141. My discussion of the Internet will provide many examples of instances in which individuals are in fact eager to publish their sentiments and ideas and place them in the public domain without retaining any exclusive rights. See Part III.

163 Indeed, in the history of our species, social exchange of information came before monetary exchange and even before the barter of information for goods. Because division of labor was not well developed in hunter-gatherer societies, the payment for information 
turn often transmit it to others either in the same form or refracted through their own intellect, thus gaining use value for themselves. ${ }^{144}$ Use value is also found in information such as specific offers and promises that have little retention value. This information nevertheless creates wealth by facilitating other transactions valuable to the transmitter, including commercial and political transactions, such as trade of material goods or political coalition building. ${ }^{145}$ Such information takes some effort to assemble and still is a valuable product for the producer, thus coming within Madison's broad definition of property. ${ }^{146}$

Thus, one reason that the First Amendment protects information even when it is not copyrightable is that individuals may realize use value from information from which they likely cannot realize retention value. The other reason that the First Amendment protects a broader class of information than copyright is that it is less costly to society to prevent the government from interfering with information transmission than it is to enforce copyright protection. So long as the government simply refrains from suppressing information and fulfills its ordinary police function of protecting persons and material property against violence and theft, ${ }^{147}$ a social exchange of information naturally occurs,

was often more information. See Wright, Moral Animal at 194-95 (cited in note 17) (In hunter-gatherer societies, "[k] nowing where a great stock of food has been found, or where someone encountered a poisonous snake, can be a matter of life or death. And knowing who is sleeping with whom, who is angry at whom, . . . can inform social maneuvering for sex and other vital resources."). Even at academic conferences that ostensibly focus on copyrightable papers, much of the interaction will be devoted to the exchange of gossip about people and positions that may affect the career prospects of the employees. For a fuller discussion of social exchange of information and its role in the evolution of human nature, see McGinnis, Information Transmission (cited in note 23).

${ }^{144}$ There is no problem in understanding that two individuals may have a right to transmit the same piece of information to gain use from it. Since we do not seek retention value in most information we transmit, many other people may have the right to transmit and so realize its use value independently. Copyright itself recognizes that two people can even have independent retention rights if each created the expression independently. See Sheldon $v$ Metro-Goldwyn Pictures Corp., 81 F2d 49, 54 (2d Cir 1936) (Hand) ("[I]f by some magic a man who had never known it were to compose anew Keats's Ode on a Grecian Urn, he would be an 'author,' and, if he copyrighted it, others might not copy that poem, though they might of course copy Keats's.").

${ }_{145}$ For the value of commitments to politics, see note 104 and accompanying text. For a discussion of the pervasive manner in which information production facilitates nonzero sum exchanges, see generally McGinnis, Information Transmission (cited in note 23).

${ }^{146}$ See Madison, Property at 266 (cited in note 45) ("In its larger and juster meaning, it embraces every thing to which a man may attach a value and have a right; and which leaves to every one else the like advantage.").

${ }^{147}$ In order to maximize the use value of information, the government also has to prevent private violence from suppressing transmission. However, the government is already obligated by the social contract to enforce criminal laws against private violence. 
as individuals continuously realize the use value of their information by transmitting it to others. ${ }^{148}$ It is the task of the First Amendment to protect this spontaneous order of information exchange from interference by the state. ${ }^{149}$

\section{The Speech and Press Clauses Under a Property-Centered Theory}

This Part sketches a construction of the Free Speech and Press Clauses based on the Madisonian/Lockean vision. ${ }^{150} \mathrm{~A}$ First Amendment rooted in a natural property right should draw on familiar concepts of natural rights and property more than current First Amendment jurisprudence does. For instance, familiar ideas in natural rights theory-such as the proposition that property cannot be used to deprive others of their property by force or fraud-provide intelligible principles which allow the Free Speech Clause to integrate a wide range of doctrines relating to permissible government restrictions on the dissemination of particular categories of information. While a property-based

14: For discussion of the way beneficial social exchange can arise without mechanisms of centralized control, see Robert C. Ellickson, Order without Law: How Neighbors Settle Disputes 230-64 (Harvard 1991).

${ }^{149}$ Under a property-centered view of the First Amendment, there is no conflict between copyright and the First Amendment when the government prohibits one author from publishing information owned by another. In that case, the government is enforcing a right in information property rather than interfering with it. It is permitting an individual to transmit his information and retain exclusive use, thus protecting the retention value of his property.

Of course, if one agrees with Professor Gordon, as against John Stuart Mill, that the Lockean proviso may be violated by granting too robust protection for intellectual property, one might well draw a different line than that which currently exists between the right of a citizen to control the dissemination of his information and the right of third parties freely to disseminate it. See Gordon, 102 Yale L J at 1565-72 (cited in note 83) (arguing against robust intellectual property rights because such rights would in many instances not leave enough and as good in common for others, thus violating the Lockean proviso). Nevertheless, even if the bundle of rights in information associated with copyright or trademarks should be differently defined by reconsidering the scope of these natural rights, the First Amendment and copyright would still be protecting complementary aspects of a natural property right in information. Moreover, nothing in Gordon's article suggests that the right as against the government to disseminate information is not a natural right. Certainly such a transmission right leaves enough and as good for everyone else.

${ }_{150}$ This Part does not purport to be a comprehensive or conclusive presentation of the First Amendment doctrines that would be developed in a property-based jurisprudence. If the Court were ever to embrace the property rationale of the First Amendment, it would undoubtedly make different choices, at least as to details. Instead, this Part seeks to show that a property-based jurisprudence can generate a set of doctrines at least as coherent as current jurisprudence. The implications of a property-based jurisprudence for commercial speech are discussed separately in Part IV. See notes 324-30 and accompanying text. 
view of the Free Speech Clause addresses restrictions on information per se, I shall suggest that the Free Press Clause is expressly designed to limit the extent to which the government may regulate the material property used for information transmission. Like the construction of the Free Speech Clause, the propertybased construction of the Free Press Clause permits a unitary analysis of numerous doctrines usually treated as unconnected, such as time, place, and manner restrictions, limits on symbolic speech, and the regulation of the mass media.

Of course, a property-centered construction of the Free Speech and Press Clauses does not dissolve all the hard questions that have bedeviled the First Amendment, but it does enable us to employ well established natural rights and property concepts to make useful analogies. Indeed, one of the advantages of understanding the First Amendment through the prism of property is the discipline it imposes on government in all its avatars-legislative, executive, and judicial. Public agencies will be forced to analyze speech issues using concepts developed without reference to any conscious or unconscious interest of rulers in suppressing or skewing speech.

\section{The Free Speech Clause.}

A natural-property-rights view of speech suggests that the Free Speech Clause should be interpreted to protect absolutely the right to transmit information, subject to the usual Lockean limitations. ${ }^{151}$ The only legitimate Lockean restrictions on the transmission of information per se are those designed to prevent information from being used to deprive others of their life or property by force or fraud. ${ }^{152}$ Under this view, there is no place for ad hoc judgments on what is intrinsically high and low value speech. ${ }^{153}$ Restrictions on the transmission of information are instead judged under a single standard that looks only to whether they threaten a deprivation of life or property by force or fraud. ${ }^{154}$ The harder questions for the theory are how stringent-

151 Locke's law of nature requires that "no one ought to harm another in his Life, Health, Liberty, or Possessions." Locke, Two Treatises at 289 (cited in note 43).

152 As we shall see, restrictions related to information-producing material property rather than to information per se are to be tested under standards derived from the Free Press Clause. See text accompanying notes 172-202.

${ }^{163}$ For a discussion of the Supreme Court's categorization of some speech as low value, see Geoffrey $\mathrm{R}$. Stone, Content Regulation and the First Amendment, $25 \mathrm{Wm} \mathrm{\&}$ Mary L Rev 189, 194-97 (1983).

${ }_{154}$ The application of a single mode of analysis, however, would not overturn all cases 
ly the requirement of force or fraud will be interpreted and what kinds of property interests will be protected from deprivation by such means.

Under any plausible interpretation of the force or fraud proviso, the property-centered Free Speech Clause would still clearly permit the punishment of criminal solicitation. A person wrongly deprives someone of property as much by ordering someone under his employ to steal it as by taking the property directly. Blackmail may also be forbidden because its natural consequence is to breed fraud and deceit-the blackmailer has every incentive to join his victim in continuing to perpetrate fraud against third parties. ${ }^{155}$

The property-centered view of the First Amendment also helps us understand the full reticulation of the clear and present danger test of Brandenburg $v$ Ohio $^{156}$ as an attempt to shape the proper boundaries of force and fraud in the context of lawlessness. Brandenburg held that speech advocating lawless action is unprotected under the First Amendment only if it is both "directed to inciting or producing imminent lawless action and is likely to incite or produce such action." 157 At the root of Brandenburg is the proposition that incitement to break the law threatens to deprive citizens of the security for property that animated the social contract in the first place. It is, therefore, a use of information that is not protected under the Lockean scheme. But Brandenburg's requirement of a likelihood of immediate success in causing lawlessness is appropriate because of the general suspicion of rulers' motives for information regulation. ${ }^{158}$ This second prong of the Brandenburg test makes it harder for government to prohibit speech that threatens the perquisites of rulers or their supporters by claiming that harm will result from a lengthy causal chain the links of which are hard to evaluate. ${ }^{159}$

that uphold government regulation of particular kinds of information. For instance, a theory rooted in property rights may provide a firmer basis for the holding of New York $v$ Ferber, 458 US 747, 773-74 (1982), that pornography produced by using children may be totally prohibited. Just as the state can prevent individuals from accepting money from a minor because a minor lacks power to consent, so can the state prohibit pornographers and users of pornography from making use of a minor's image, another form of property.

w5 See Richard A. Epstein, Blackmail, Inc., 50 U Chi L Rev 553, 564-65 (1983).

L6 395 US 444 (1969).

157 Id at 447.

159 For discussion of the reasons for such suspicion, see notes 102-12 and accompanying text.

${ }_{159}$ Originally, "fighting words" were punishable without regard to their likelihood of 
Brandenburg's first prong, requiring that the speaker intend to produce imminent lawless action, also flows directly from the Madisonian/Lockean theory of the First Amendment. If the focus were on the actions of the audience alone, the test would permit the so-called heckler's veto: by threatening violence or riot the audience could effectively silence the speaker. ${ }^{160} \mathrm{~A}$ rule that focused on the reaction of the audience rather than the intent of the speaker would encourage audiences to behave badly in reaction to speech they opposed in the hope that it would be suppressed. Such a rule would drive society back to a kind of state of nature where one individual could with impunity deprive another individual of his property-in this case the use value of his information. The whole point of a Lockean scheme, however, is to make rights more secure by substituting the rule of law for the state of nature. Thus, the heckler's veto creates opportunities for the systematic theft of individuals' property in their information. As such, it has no place in the Madisonian/Lockean First Amendment.

Since the sole basis for restricting information under the Lockean scheme is deprivation of property (or life), the property concepts of the common law-themselves developed under the strong influence of natural rights theory-can also help us determine what interests may be legitimately protected against injury by speech. ${ }^{161}$ The longstanding nature of the concepts also provides assurance that the interests the government protects in this context have not been chosen with an intention of suppressing or manipulating speech. Some interests are uncontroversial: the interests in real and personal property have long been protected at common law and by statute against private violence and fraud. Their status as property in our legal system can hardly be attributed to any interest in repressing speech. An individual's

causing a breach of the peace. See Chaplinsky $v$ New Hampshire, 315 US 568, 574 (1942). The movement in current law is to incorporate the "clear and present danger" test into the fighting words doctrine, and thus permit the regulation of fighting words only insofar as they are intended to, and are likely to, cause immediate disruption. See Nadine Strossen, Regulating Racist Speech on Campus: A Modest Proposal?, 1990 Duke L J 484, 508-14 (outlining current trends in fighting words doctrine). Thus, in this area, current law approximates the kind of standard a property-based jurisprudence would embrace.

160 See David P. Currie, The Constitution in the Supreme Court: 1946-1953, 37 Emory L J 249, 265 (1988) (pointing out that early versions of the clear and present danger test facilitated the heckler's veto because they did not take account of the intent of the speaker).

161 Even opponents of a natural rights jurisprudence concede that the development of the common law resulted in categories shaped by theories of natural rights. See Cass $R$. Sunstein, Lochner's Legacy, 87 Colum L Rev 873, 879 (1987). 
interest in reputation also was recognized as a property right at common law. ${ }^{162}$ It is true that this interest can be injured only by information transmission and redressed only by slander or libel law, thus perhaps raising suspicion that it was created to facilitate the suppression of speech. Nevertheless, reputation is closely related to other common law property interests that had important roles in contexts other than speech-related torts, such as goodwill ${ }^{163}$ and the right of publicity. ${ }^{164}$ Given reputation's place in the web of the common law, it is hard to argue that reputation's status as a property interest was established simply for the purpose of suppressing speech. Under a property-based understanding, libel laws thus do not necessarily violate the First Amendment.

A property-based understanding does suggest, however, that the Court is correct to temper the law of libel to keep the protection of reputation within proper bounds. The Madisonian/Lockean regime distinguishes natural rights from the political structure created to protect these rights. Accordingly, while the reputation one acquires in the private sphere is property to be protected, reputation in the political realm is merely part of the instrumental political structure for the protection of property. ${ }^{165}$ Libel and slander laws in this distinct context are best understood as means of protecting the position of the rulers-one of the very considerations that moved the Framers to give information property special constitutional protection. Therefore, public officials are not entitled to the same safeguards for their public reputations. The implications of the Lockean view thus suggest that in New York Times Co. $v$ Sullivan, Justices Black and Douglas may have been justified in arguing that the press should be absolutely immune from liability for criticizing the way public officials do their public duty. ${ }^{166}$

${ }^{162}$ See Alain Sheer and Asghar Zardkoohi, An Analysis of the Economic Efficiency of the Law of Defamation, $80 \mathrm{Nw}$ U L Rev 364, 369 (1985).

163 The reputation of an individual is much like the goodwill of a business. See Stewart E. Sterk, Restraints on Alienation of Human Capital, 79 Va L Rev 383, 438-41 (1993) (Common law recognized property interest in goodwill.).

is See Michael Madow, Private Ownership of Public Image: Popular Culture and Publicity Rights, 81 Cal L Rev 125, 132 \& n 23 (1993), citing J. Thomas McCarthy, The Rights of Publicity and Privacy § 6.1[B] at 6-5 to 6-8 (Clark Boardman Callaghan 1990) (right now recognized in fifteen states).

365 Another way of looking at this is to view reputation in the political realm as a kind of property of the political system rather than as individual property. This view would also provide support for lobbying restrictions by former government officials who are trying to profit from what is not truly theirs-their reputation gained through politics.

${ }_{105} 376$ US 254, 293 (1964) (Black, joined by Douglas, concurring). Under this view, 
Under a property-based theory of the First Amendment, hate speech regulations would likely be invalidated. ${ }^{167}$ To defend hate speech codes in a property-based regime, one would have to posit a property interest in self-esteem to be protected against injury by hate speech. Property interests in self-esteem were not well established at common law. ${ }^{168}$ Moreover, unlike injury to tangible property interests or even reputation, injury to self-esteem-whether understood as that of an individual or that of a group-raises enormous difficulties of objective proof. Thus, it gives rise to inherent dangers of discrimination against First Amendment rights. ${ }^{169}$ Moreover, since no one advocates strict liability for all speech that intentionally causes emotional disturbance, hate speech regulation poses a serious dilemma. Enabling each person to determine for himself which feelings are to be protected against speech is to permit a heckler's veto. ${ }^{170}$ On the other hand, allowing the government to pick and choose what

however, the Court is probably wrong to extend the limited immunity afforded criticism of public officials to "public figures." See Curtis Publishing Co. v Butts, 388 US 130, 154-58 (1967) (football coach held to be "public figure" and subject to New York Times $v$ Sullivan standard). General fame is a private asset and thus can be protected as a personal reputational interest under the libel laws. For discussion of why the negligence standard rather than strict liability should be applied in libel cases, see note 185 .

167 Sometimes hate speech may constitute fighting words that may be appropriately punished under the property-based view of the First Amendment. See note 159. The Supreme Court recently invalidated a hate speech ordinance on the grounds that it was radically underinclusive as to the kinds of words it covered. See R.A.V. $v$ City of St. Paul, 505 US 377, 380 (1992) (invalidating statute that punished expression arousing "anger, alarm or resentment in others" on the basis of a limited number of categories). For a discussion of the role of underinclusiveness in a property-based First Amendment jurisprudence, see notes 181-202 and accompanying text.

${ }_{165}$ Even proponents of hate speech regulation concede that such feelings were not historically protected at common law against injury by speech. See Jean C. Love, Discriminatory Speech and the Tort of Intentional Infliction of Emotional Distress, 47 Wash \& Lee L Rev 123, 126 (1990) (noting that courts followed the proverb "[s]ticks and stones may break my bones, but names will never hurt me").

${ }^{109}$ See John M. Blim, Undoing Our Selves: The Error of Sacrificing Speech in the Quest for Equality, 56 Ohio St L J 427, 476 (1995) ("The attempt to distinguish racist and sexist speech from other types of offensive speech can only be based on the strength of the emotions it creates in its critics, something less than an objective barometer of what kinds of speech must be suppressed."). Reviewing a claim for damages stemming from outrageous parody, the Supreme Court recently noted the danger that a tort of intentional infliction of emotional distress based on comment or opinion could pose to the First Amendment: "Outrageousness' in the area of political and social discourse has an inherent subjectiveness about it which would allow a jury to impose liability on the basis of the jurors' tastes or views, or perhaps on the basis of their dislike of particular expression." Hustler Magazine, Inc. v Falwell, 485 US 46, 55 (1988).

170 For a discussion of the heckler's veto and Lockean theory, see text accompanying notes $160-61$. 
feelings to protect would pose obvious dangers of political manipulation. ${ }^{171}$

\section{The Free Press Clause.}

Turning from the Free Speech Clause's treatment of restrictions on information per se, we look to the property-based construction of the Free Press Clause to address one of the most recurrent and intractable problems in First Amendment jurisprudence-the appropriate standard for assessing government regulation of the material property used to transmit information. Given that material property is essential to the transmission of much information, how can the government's general authority to regulate material property be prevented from becoming a vehicle to suppress or skew speech? ${ }^{172}$ This issue arises under various doctrinal headings-symbolic speech (where the symbols are generally material); time, place and manner regulation (where the regulation is of material property); and taxation and regulation of information-producing enterprises (where media enterprises, like other enterprises, use material processes of production).

All of these problems share a common connection to a property-based understanding of the Press Clause. ${ }^{173}$ Understanding that the protection of transmission rights increases the use value individuals enjoy in their information clarifies the special focus on the press in the text of the First Amendment: the press at the time of the Framing was the most efficient medium through which individuals could disseminate their ideas and sentiments most widely and therefore most beneficially. ${ }^{174}$ Of course, this

171 Compare R.A.V., 505 US at 391 (invalidating statute that prohibited only certain kinds of epithets on grounds that selective prohibition was a form of government censorship).

${ }_{172}$ As we have seen, the Takings Clause does not prevent the government from regulating material property. See notes $113-21$ and accompanying text.

${ }^{173}$ The relation between the Speech and Press Clauses has puzzled scholars, with most viewing the Clauses as expressing a single idea. See David A. Anderson, The Origins of the Press Clause, 30 UCLA L Rev 455, 456-57 (1983) (discussing interpretations of the relationship). The Court has never relied on the Press Clause alone to decide the outcome of any case. Id at 457.

${ }_{174}$ There is substantial evidence that the Framers included freedom of the press because it was the medium for publishing thoughts to a wide audience. Pennsylvania, the first of the three states to recommend a Press Clause, made this relationship clear in its proposal: "That the people have a right to the freedom of speech, of writing and of publishing their sentiments; therefore, the freedom of the press shall not be restrained by any law of the United States." See Pennsylvania Convention Debates, 1787, in Bernard Schwartz, 3 The Roots of The Bill of Rights 641, 658 (Chelsea House 1980). Virginia and 
medium, like modern media of mass communication, required substantial material property and personnel to propagate information. Thus the problem of protecting the press was and is emblematic of the more pervasive need to protect informationproducing property from government suppression and manipulation.

As discussed above, the struggle for a free press in England was a struggle to liberate the press from the peculiar system of centralized control that had been imposed on it through the Regulation of Printing Acts. ${ }^{175}$ Indeed, Blackstone wrote that "the press became properly free, in 1694 [the date Parliament failed to renew these acts]; and has ever since so continued." 176 A free press, of course, did not mean a press free from all regulation: the press was certainly subject to other generally applicable laws. ${ }^{177}$ By the time of the Framing, however, a free press was generally understood to encompass freedom from special rules not generally applicable to business enterprises, such as laws that required licenses or permitted the government to confer monopoly rights on favored citizens. ${ }^{178}$

North Carolina substantially tracked Pennsylvania's language in this regard. See Virginia Ratifying Convention, 1788, in Bernard Schwartz, 4 The Roots of The Bill of Rights 766, 842 (Chelsea House 1980); North Carolina Convention Debates, 1788, in Bernard Schwartz 4 The Roots of The Bill of Rights 933, 968 (Chelsea House 1980). Madison's first proposed wording of what are now the Free Speech and Free Press Clauses similarly incorporated the notion of publishing sentiments as a description of the press's function. See 1 Annals of Cong 451 (June 8, 1789) ("The people shall not be deprived or abridged of their right to speak, to write, or to publish their sentiments; and the freedom of the press, as one of the great bulwarks of liberty, shall be inviolable.").

Thus, as a matter of constitutional history, the speech right is clearly not an afterthought, although I recognize that for much of colonial history the freedom of the press, rather than the freedom of speech, was at the center of the struggle for individual rights against the state. See Anderson, 30 UCLA L Rev at 533 (cited in note 173).

${ }^{175}$ See text accompanying notes $46-52$.

176 William M. Blackstone, 4 Commentaries $* 152 \mathrm{n}$ a. For further discussion of this point, see Mayton, 38 Emory L $J$ at $720-27$ (cited in note 40 ).

177 Social and regulatory norms with respect to material property at this time were largely libertarian. The common law had evolved to facilitate the enjoyment of individual property rights: acquisition, possession, use and disposition. See Carol M. Rose, Possession as the Origin of Property, 52 U Chi L Rev 73, 73-75 (1985) (Both Locke's labor theory of property and the common law possession theory provided individuals with substantial property rights.). Whether the common law evolved these rules to maximize efficiency and promote wealth creation, see Richard A. Posner, Economic Analysis of Law 28-31 (Little, Brown $2 d$ ed 1977), or to mask the irreconcilable contradiction between autonomy and community, has been disputed. See Duncan Kennedy, The Structure of Blackstone's Commentaries, 28 Buff L Rev 205, 211-17 (1979).

${ }_{178}$ There is substantial agreement that the concept of the freedom of the press precluded federal licensing laws or government-enforced monopolies. Scholars also agree that the Free Press Clause precluded prior restraints. See Leonard W. Levy, ed, Freedom of the 
The general principle that emerges from the history of the press known to the Framers is that the way to protect material property rights essential to the operation of the press was to ensure, at the very least, that only rules of the kind that were applied to other business enterprises could be applied to the press. ${ }^{179}$ This principle also comports with the rationale for providing special protection to property in information-fear of government suppression and manipulation. ${ }^{180}$ If the government is prevented from applying special rules to the material property used for information production, there is substantial assurance that the government is not framing the rules to interfere with property in information. Under this view, laws of general applicability, such as employment or antitrust laws, may be applied to the material property used for information transmission, but laws imposing special burdens or departing from general norms applicable to property used for purposes other than information transmission are forbidden. ${ }^{181}$

Restrictions on information-producing property may depart from norms in at least two ways. First, the restriction may be underinclusive in that it is not generally applied to other uses of the property that have similar effects. Second, the restriction may also be underinclusive in that it is not generally be applied to similar information-producing property. Either kind of depar-

Press from Zenger to Jefferson: Early American Libertarian Theories lv (Bobbs-Merrill 1966). Like a licensing law, a prior restraint can be understood as a deviation from the common law's treatment of business enterprises; under the common law, other enterprises were not normally subject to licenses or prior restraints, but rather only to after-the-fact liability for damages they caused. Of course, I am not arguing here that all the Framers immediately understood all the implications of this emerging principle.

173 William Van Alstyne makes a similar point about both the First and Second Amendments. He suggests that these amendments permitted citizens to be held accountable for abusing firearms or the press, but prevented the government from forbidding or specially licensing these items as a precaution against abuse. See William Van Alstyne, The Second Amendment and the Personal Right to Arms, 43 Duke L J 1236, 1250 (1994).

${ }_{180}$ For discussion of the place of this rationale in the property-based theory, see notes 102-12 and accompanying text.

${ }^{131}$ If this interpretation of the Press Clause is to offer substantial protection to transmission rights, the requirement that regulation be no more burdensome than the norm applied to similar property used for purposes other than information transmission is an important one. Because of interest group politics, some kinds of material property are likely to be regulated more than the norm. If the most heavily regulated similar property were the standard for the regulation of property used for information transmission, much transmission could be curtailed. The emphasis on the regulatory norm seems consistent with original operation of the Clause. While at the time of the Framing, licensing requirements had been applied to some enterprises other than the press, such requirements were not the norm. 
ture from regulatory norms would violate a property-based understanding of the First Amendment. ${ }^{182}$

This interpretation of the Press Clause-as restricting the government's authority to regulate the material property used for information transmission-provides a unitary analysis of First Amendment law that can be applied across disparate doctrinal areas. ${ }^{183}$ Although the Court has never expressly adopted this theory of the Press Clause, cases concerning the regulation and taxation of media enterprises come close to the implicit use of such an analysis. For instance, in Minneapolis Star \& Tribune Co. $v$ Minnesota Comm'r of Revenue, the Court struck down a "use tax" on paper and ink products because it was not applied to the inputs of other business enterprises. ${ }^{184}$ More recently, in Cohen $v$ Cowles Media Co., the Court upheld a plaintiff's right to recover damages for breach of a newspaper's promise of confidentiality because the doctrine of promissory estoppel under which the plaintiff sued applied equally to media and other enterprises. ${ }^{185}$

${ }_{182}$ Since the construction of the Free Press Clause offered here is designed to prevent the government from discriminating against information-producing uses of material property, it is not surprising that it has much in common with underinclusiveness analysis of the Equal Protection Clause, since that too is built around an antidiscrimination principle. See Owen M. Fiss, Groups and the Equal Protection Clause, in Marshall Cohen, Thomas Nagel, and Thomas Scanlon, eds, Equality and Preferential Treatment 84, 97-98 (Princeton 1977) (arguing that antidiscrimination principle is at the heart of the underinclusiveness analysis in the Equal Protection Clause context). See also Melville B. Nimmer, The Meaning of Symbolic Speech Under the First Amendment, 21 UCLA L Rev 29, 39-42 (1973) (criticizing overly narrow statutes that restrict symbolic speech).

133 The interpretation of the Press Clause offered here has some kinship with the Court's recent decision in Employment Division v Smith, 494 US 872, 879 (1990), where the Court held that the Free Exercise Clause was not violated by laws that were neutrally applied to a religious practice even if they burdened that practice. This construction of the Press Clause also focuses on a question of neutral application-whether rules designed to protect against certain harms are equally applied to property used for information transmission and property used for other purposes.

${ }_{184} 460$ US 575, 582-85 (1983). The Court held that the tax was unconstitutional on two separate grounds: the tax was applied uniquely to newspapers, see id at 586-90, and the tax was applied selectively to a small group of newspapers, see id at 591-92.

185501 US 663, 669-70 (1991). The debate over the proper tort standards in libel actions can be framed in a similar manner. Since tort actions against enterprises producing material goods generally require proof of actual damages, the Court has rightly been suspicious of strict liability and presumed damages in the libel context. See Gertz $v$ Robert Welch, Inc., 418 US 323, 349 (1974) (holding that the First Amendment prohibited presumed damages, at least when plaintiffs do not prove knowledge of falsity or reckless disregard for the truth). See also David A. Anderson, Reputation, Compensation, and Proof, 25 Wm \& Mary L Rev 747, 774-78 (1984) (arguing that defamation actions should generally be subject to the same proof demands as other torts). Similarly, if most torts require proof of negligence, and do not presume its existence, such proof should be required in the libel context as well. 
The constitutionality of regulation of public property should be viewed through the same prism. Although streets are publicly owned, citizens have the equivalent of easements in streets through which they are free to convey their bodies and material property. On this account, they may also use streets to convey or display their property in their information. ${ }^{186}$ Of course, just as the state regulates the use of streets to prevent nuisances caused by the use of material property (I can't walk down the street with a huge burning torch), the state can prevent the use of streets for information transmission where such transmission will have effects similar to the effects of other prohibited uses of material property. ${ }^{187}$ For instance, demonstrations may be prohibited outside schools, if the city would also prevent the use of material property with effects similarly distracting to children at the school. ${ }^{188}$

Of course, establishing a constitutional baseline that requires one to compare time, place, and manner regulations with regulations on the use of streets for purposes other than information transmission does not remove the need for judgment in hard cases. But the focus on property rights does provide helpful guides from contexts where the state has formulated rules not aimed at suppressing speech. ${ }^{189}$ For instance, in Heffron $v$ Intl Soc'y for Krishna Consciousness, Inc., the Court permitted the county to restrict distributors of literature at a state fair to fixed

${ }_{186}$ Thus, Professor Kalven was correct to say that individuals had a "kind of FirstAmendment easement" in streets and parks, see Harry Kalven, Jr., The Concept of the Public Forum: Cox v. Louisiana, $1965 \mathrm{~S} \mathrm{Ct} \operatorname{Rev} 1,13$, but the source of that right should be found in the non-First Amendment easement that permits individuals to use streets and parks for all sorts of non-information-producing purposes. The easement for information production may be circumscribed only on the same principles by which the non-First Amendment easement is circumscribed. See note 187 (discussing nineteenth-century cases that undertake this kind of analysis).

${ }_{187}$ Some nineteenth-century state courts employed a similar theory to provide free speech protection to demonstrations conducted on public property. They held that demonstrations could proceed unless they created effects that would be prohibited under the common law of nuisance. See In the Matter of Frazee, 63 Mich 396, 30 NW 72, 74 (1886) ("A A]n actual nuisance can be suppressed just so far as it is noxious, and its noxious character is the test of its wrongfulness."); Anderson $v$ City of Wellington, 40 Kan 173, 19 P 719, 722 (1888) (striking down ordinance preventing public assemblies on the grounds that it precluded traditional uses of public property that did not cause a nuisance).

${ }_{1 \times s}$ See Grayned $v$ City of Rockford, 408 US 104, 117-21 (1972) (upholding ordinances prohibiting loud demonstrations on streets next to a school during class hours).

$1: 9$ For instance, in evaluating whether the state is affording similar treatment, a court might assess the diminution in property values caused by adult entertainment and other nuisances that the state does not regulate. 
booths. ${ }^{190}$ The constitutionality of such a restriction under the analysis offered here would depend on whether the state imposed similar regulations on other enterprises, such as balloon or food sellers. ${ }^{191}$

Consider also City of Renton $v$ Playtime Theatres, Inc., in which the Court upheld a zoning ordinance that prohibited adult theaters from locating within one thousand feet of any residential zone, dwelling, church, park, or school. ${ }^{192}$ While the Justices debated whether the restriction was content based, ${ }^{193}$ the question under a property-based theory would have been whether the city similarly restricted uses of material property that would have adverse effects similar to those created by adult movies. ${ }^{194}$ For instance, if a city consistently applied similar zoning restrictions to uses of material property that had similar deleterious effects on the value of surrounding property, the adult theater ordinance should be upheld. ${ }^{195}$

The regulation of symbolic speech can be addressed in a similar manner. Symbolic speech is expression created by the manipulation of material objects: regulation of these materials is suspect if the government does not similarly regulate like material property when it is put to uses which have similar effects. Under this analysis, the questions now asked in symbolic speech cases would change. For instance, in United States $v$ $O^{\prime}$ Brien $^{196}$ - the case that considered whether a statute penal-

190452 US 640, 654 (1981).

191 It appears the rules did apply equally to all enterprises, information-producing and non-information-producing. Id at 643-44.

${ }^{192} 475$ US 41, 54-55 (1986).

193 Compare id at 46-49 (Rehnquist), with id at 56-58 (Brennan dissenting).

194 Justice Brennan did observe that the zoning ordinance seemed underinclusive because it did not apply equally to all adult entertainment. City of Renton, 475 US at 5758 (Brennan dissenting).

195 Of course, if consumers of adult entertainment were to review the materials in their homes, such activity would be no more likely to affect surrounding property values than many other domestic activities. Because the state does not regulate the use of homes for such domestic activity, it would face great difficulty in justifying regulation of indecent or even obscene material in the home. See Stanley $v$ Georgia, 394 US 557, 565 (1969) (State cannot punish a person for reading obscene material in his own home.). The digital revolution, see text accompanying notes $246-53$, will give rise to increased opportunity to access such materials through cable or telephone wires.

Under the property-based theory, one could regulate pornography if it created the equivalent of a clear and present danger of causing rape or other conduct that would interfere with others' natural rights. Most analysis of pornography suggests that it does not create such a danger. See Richard A. Posner, Sex and Reason 366-72 (Harvard 1992) (reviewing the literature on the relationship between pornography and sex crimes).

196391 US 367 (1968). 
izing the burning of draft cards violated the First Amendment-the Court did not directly focus on the issues that would be dispositive under a property-based jurisprudence: (1) whether the regulation relating to the draft cards applied equally to communicative and noncommunicative acts that rendered draft cards unavailable for their governmental use, and (2) whether similar regulations were applied to similar material property (such as social security cards and other important documents issued by the government). Instead the Court suggested that the draft card mutilator who had an expressive purpose deserved some First Amendment protection irrespective of how the regulation dealt with those who mutilated similar documents for nonexpressive purposes. ${ }^{197}$ The central question for the Court was whether the protester's First Amendment interest was outweighed by the government's interest in enforcing the regulation. ${ }^{198}$

Even though the test suggested here for symbolic speech does not confer a special First Amendment privilege on the user of material property for symbolic communicative conduct, it may in many cases be more protective of speech than the test announced in O'Brien, because in applying that test, courts tend to defer to the government's interest in regulating material. ${ }^{199}$ The property-based test would more stringently assess the government's neutrality and good faith. For example, in O'Brien itself, the property-based test might well have resulted in reversal of the draft protester's conviction. The burdens of the regulation in that case did not fall equally on all those who made their draft card unavailable for official purposes, but rather fell on those who knowingly destroyed or knowingly mutilated their draft cards. ${ }^{200}$ (For instance, the regulation did not appear to

197 Id at 376-77. See also William W. Van Alstyne, First Amendment: Cases and Materials 253-54 (Foundation 1991) (questioning whether those who violate a law to make a political point should be given special First Amendment protection).

${ }^{193}$ O'Brien, 391 US at 377 ('[A] government regulation is sufficiently justified . . . if it furthers an important or substantial governmental interest ... unrelated to the suppression of free expression...."). Some commentators have thought this is less a balancing test than a "no gratuitous inhibition" test. See John Hart Ely, Flag Desecration: A Case Study in the Roles of Categorization and Balancing in First Amendment Analysis, 88 Harv L Rev 1482, 1490 (1975). Conceptualized as such, the O'Brien approach is far less protective of speech than the balancing test used in cases involving "more familiar forms of expression" and that concern time, place, and manner regulations. Id. One of the advantages of the property-based construction of the First Amendment is that it creates a single test for both familiar and unfamiliar uses of material property for expressive purposes.

${ }^{6} / \mathrm{E}$ Ely, $88 \mathrm{Harv} \mathrm{L}$ Rev at $1484-89$ (cited in note 198 ).

20\% O'Brien, 391 US at 370. 
apply to those who knowingly lost their draft cards. ${ }^{201}$ ) Moreover, there is a serious question whether the regulation was the norm applied to similar property such as other government identity documents. Indeed, legislative history quoted in O'Brien suggests that Congress passed the regulation for draft cards alone, and that at least some members of Congress were motivated by animosity toward antiwar protesters. ${ }^{202}$

To sum up: besides its consonance with the actual theory underlying the original First Amendment, the new approach has several advantages over traditional jurisprudence. ${ }^{203}$ First, it discards the unprincipled and unstable distinction between highand low-value speech; instead, the property-based interpretation provides a unitary standard of force and fraud for evaluating government restrictions on information. Second, by subjecting all regulations of information-producing property to a test designed to discover government suppression of speech, it would minimize

201 Professor Nimmer suggests that the "overnarrowness" of the statute suggested that the government was targeting expressive conduct. See Nimmer, 21 UCLA L Rev at 40-41 (cited in note 182).

${ }^{202}$ O'Brien, 391 US at $385-86$ (noting that legislative history was specifically concerned with "defiant" destruction of draft cards).

Thus, under the property-based view, both of the recent flag burning cases were rightly decided. The statute at issue in Texas $v$ Johnson punished desecration of the flag-that is, action with respect to the flag that offended other individuals. 491 US 397, $400 \mathrm{n} 1$ (1989). There, burning the flag to produce information (about the flag-burner's attitude toward the United States) was treated differently from burning the flag for other communicative purposes or no communicative purpose at all. (For arguments that offensiveness to other individuals is not a legitimate reason to distinguish the effects of actions, see notes 167-71 and accompanying text.) Thus, the government regulated an information-producing use of material property differently than it regulated other uses, in violation of a property-based understanding of the First Amendment. In United States $v$ Eichman, the statute ostensibly punished all knowing mutilation or burning of the flag regardless of purpose. 496 US 310,314 (1990). Nevertheless, the statute made exceptions permitting the burning of "soiled or worn" flags. Id at 317. Moreover, the government conspicuously failed to regulate other similarly situated property-like the flags of other nations, the burning of which differs in its effects only in that it is less offensive. Thus, the statute in Eichman also treated flag burning differently than similarly situated property and should likewise have been invalidated under a property-based understanding of the First Amendment.

${ }_{203}$ Under the current "two-track" approach, if the government regulation is "content based"-that is, aimed at the communicative impact of the activity regulated-it is subject to strict scrutiny and will be struck down unless supported by a substantial interest. Laurence H. Tribe, American Constitutional Law $\$ 12-2$ at 789-92 (Foundation 2d ed 1988). If the regulation is not content based, it will be upheld so long as it does not "unduly constrict" the flow of ideas. Id at 792. In contrast, under the property-centered view, information itself can be regulated only on the basis that it threatens others' property through force or fraud. On the other hand, the material property used for information production may be regulated only to the extent that similarly situated material property is similarly regulated. 
the importance of the distinction between content- and non-content-based regulation-a notorious source of contention and confusion. ${ }^{204}$ Moreover, this inquiry would replace the balancing test traditionally applied to non-content-based restrictions. That test has been heavily criticized for requiring the courts to engage in ad hoc weighing of the incommensurable interests of the citizen's freedom to speak against the government's interest in regulation. ${ }^{205} \mathrm{By}$ comparing the contested regulation with the regulatory norms under which the government treats activity with similar effects or under which it treats similar property, this approach should prove less indeterminate than the existing balancing test. ${ }^{206}$ Thus, the property-based test should make it more difficult for the government to reduce speech opportunities unfavorable to the rulers. ${ }^{207}$

Under a property-centered view of the First Amendment, however, there may be one additional basis for regulating the press and similar instruments of mass communication. When the material used for propagation of information does not meet the Lockean proviso for sustaining property rights-for instance, if the material is too scarce to leave "as much and as good in common," thus precluding opportunities for communication-there may be a Lockean argument for special regulation of means of communication limited to addressing this problem. ${ }^{208}$ In the next Part, I discuss what the property-based interpretation of the Speech and Press Clauses, including the Lockean proviso, suggests for government regulation of the modern networks that are today's most efficient media for the wide and beneficial transmission of information.

204 See Martin H. Redish, The Content Distinction in First Amendment Analysis, 34 Stan L Rev 113, 113 (1981) (stating that the Court's content distinction is both "theoretically questionable and difficult to apply").

${ }_{205}$ See Larry A. Alexander, Trouble on Track Two: Incidental Regulations of Speech and Free Speech Theory, 44 Hastings L J 921, 945-47 (1993) (criticizing the coherence of the balancing tests employed to analyze non-content-based restrictions).

its For discussion of the way in which such a comparison may be made, see text accompanying notes 192-95.

${ }_{207}$ For a specific example of how this property-centered analysis catches governmental manipulations, see Part III.B.

${ }_{208}$ For discussion of the Lockean proviso and Madison's adaptation of it, see text accompanying notes $80-83$. 


\section{PROPERTY RIGHTS AND THE NET}

Were James Madison drafting the First Amendment today, he might well word it: "Congress shall make no law abridging the freedom of speech, or of the net." The net would have replaced the press because computer networks are fast becoming the most cost-effective way of delivering information. Therefore, they are becoming the medium in which citizens can most effectively realize the use value of their information. Indeed, the development of such nets represents yet another important step in what is likely the long-term trend most important to civilization's progress: the decreasing cost of transmitting information to others. ${ }^{209}$

\section{A. The Spontaneous Order of the Internet}

The Internet is the best known and most wide-ranging of the computer networks. Its growth is an example of spontaneous order arising from the decisions of thousands of individuals and corporations without the central direction of the state. ${ }^{210} \mathrm{Al}-$ though the first network or net of computers that came to compose the Internet was established by the United States as part of the defense system, and funding for this network subsidizes the system, ${ }^{211}$ government involvement is not a necessary precondi-

${ }^{209}$ The decreasing cost of producing information-caused first by the invention of the printing press, then by the application of methods of the industrial revolution to printing, and finally by the ongoing revolution in electronics and computers-is detailed in Ithiel de Sola Pool, Technologies of Freedom 11-22 (Belknap 1983). For concrete examples of the transformations in politics and business that may result from declining information costs, see text accompanying notes 298-300.

I disagree with Professor Katsh's claim that technological revolution changes our culture or way of thought by bringing with it a new internal logic (as when he suggests that the print revolution encouraged linear thinking which itself facilitated the concepts of rights). See M. Ethan Katsh, Rights, Camera, Action: Cyberspatial Settings and the First Amendment, 104 Yale L J 1681, 1685-92, 1700-12 (1995). Evolution has given us innate modes of thought and goals. Each information revolution has simply enabled us to exercise our powers of raciocination and pursue our goals more efficiently. The lower transaction costs associated with the more efficient delivery of information are principally responsible for transforming the institutions that shape culture.

${ }^{210}$ For a discussion of the concept of spontaneous order, see F.A. Hayek, The Fatal Conceit: The Errors of Socialism, in W.W. Bartley, III, ed, 1 The Collected Works of F.A. Hayek 3, 6, 83-84 (Chicago 1988).

${ }_{211}$ See Where Did the Internet Start?, Christian Sci Monitor 10 (July 18, 1994) (noting that Internet began as an Advanced Research Projects Agency network called Arpanet). Decades ago it would have been thought beneath the dignity of a law review to cite a popular newspaper, but now newspapers and magazines are frequently cited in law reviews. Law review writing is not a self-enclosed world; it is imbedded in a larger network of information exchange. It is already part of an interlocking network of communication systems, and will soon be physically part of the Internet, as a file for law review articles 
tion for creating a wide ranging net. In Europe, for instance, a vast network called Eunet has been created by telephone companies and other telecommunication providers. ${ }^{212}$

Moreover, the growth of the Internet was neither anticipated nor encouraged by government; it was first spurred by the academic community. Universities sought to connect their different departments through e-mail. ${ }^{213}$ These universities then connected to the defense system and one another in a way that left no one net in charge of the aggregation of networks. ${ }^{214}$ Commercial networks are now arising to connect individuals outside the university community. These private networks range from the million-strong Prodigy to smaller but more sophisticated operations such as Pipeline. ${ }^{215}$ The Internet encompasses more than e-mail communications. Universities and other institutions have created various databases that are freely accessible. ${ }^{216}$ Educational and commercial services are developing routines-called, inter alia, gophers, browsers, and spiders-to help Internet users find their way through the web of information to the appropriate databases. ${ }^{217}$ With the rise of Internet connections, individuals have begun special discussion groups, where parts of cyberspace are dedicated to specific topics from politics to theater to engineering to jokes, as well as subtopics of these categories. ${ }^{218}$ Today, the Internet continues to grow exponentially. ${ }^{219}$

is integrated into that system.

${ }_{212}$ See Dan L. Burk, Patents in Cyberspace: Territoriality and Infringement on Global Computer Networks, 68 Tulane L Rev 1, 18 (1993) (discussing private networks).

${ }_{213}$ See Where Did the Internet Start?, Christian Sci Monitor at 10 (cited in note 211).

For a general history of the Internet, see Daniel P. Dern, The Internet Guide for New Users 8-18 (McGraw-Hill 1994).

${ }^{214}$ Discussion groups on the Internet take a variety of forms, including newsgroups on Usenet and mailing lists such as listservs. Usenet is a worldwide discussion system with a set of "newsgroups" that are classified by subject matter. Messages may be posted to these groups by those with appropriate computer programs, and read by anyone on the Internet whose provider allows access to the particular newsgroup. Harley Hahn and Rick Stout, The Internet Complete Reference 162-63 (McGraw-Hill 1994). A mailing list permits individuals to send e-mail to all who have signed up on the list. Id at 529-33. In this Article, I use the term "discussion group" to include both kinds of mechanisms for exchanging information.

215 See Elizabeth Corcoran, Apple Joins Expanding On-Line World: Graphics, Loyal Users Provide an Edge, Wash Post Washington Business 17, 23 (June 20, 1994) (discussing the variety of competing commercial Internet connections).

${ }^{216}$ Philip Elmer-Dewitt, Battle for the Soul of the Internet, Time 50, 52-53 (July 25, 1994).

${ }^{217}$ Id at 53.

21* See id at 53-54 (discussing wide variety of newsgroups).

${ }^{219}$ See Peter H. Lewis, Doubts Raised on Number of Internet Users, NY Times D1 (Aug 10, 1994) (suggesting widespread agreement that the number of Internet users is 
Thus, the Internet in particular, and computer networks in general, demonstrate the property-centered theory of speech in action because they show both the importance of the use value of information and the manner in which individuals spontaneously deploy material property to maximize the value of information, including its use value. First, computer nets show that individuals may realize use value from information from which they realize no retention value. Many users are pleased to have their messages broadly disseminated by those who receive them; in return they obtain return information or improved reputation. ${ }^{220}$ Information transmitted through the Internet may also facilitate other valuable private, commercial, or even political transactions. ${ }^{221}$

Second, computer nets show how, in the absence of government regulation, individuals spontaneously deploy material property to increase its value, including its use value. The growth in transmission links in nets is propelled by the exercise of private property rights of individual and corporate entities of various kinds as they pursue their own interests. For instance, commercial services have arisen that permit consumers to connect to the Internet. Universities provide links to aid their employees, in the expectation that the employees will use them in a way that will redound to the overall benefit of the universities. ${ }^{22}$ This growth has been achieved with no guidance from the state and little regulation outside the enforcement of private ordering through contract. $^{223}$

doubling every year). There is disagreement on whether this growth is quite as dynamic as it seems. Some of the growth comes from networks that offer access to the Internet only for limited purposes such as e-mail. Id at D4. However, it is hardly surprising that consumers first will use the most user-friendly features of the Internet. As features such as search routines make other aspects of the net more friendly to the less initiated, we can expect growth in uses beyond e-mail.

220 Some of the return information may simply be information about who is interested in the information the senders transmit. Such information is valuable in itself because it may reduce the search costs of finding potential customers, partners, or other commercial opportunities. Nevertheless, some e-mail senders may wish to keep retention rights in the information that they send to discussion groups and other individuals. For a discussion of how to create rules protecting retention rights in cyberspace, see note 236 .

${ }_{221}$ Individuals in fact have found mates through e-mail. See Tom Steinert-Threlkeld, Virtual Marriage, Dallas Morning News 1A, 1A, 7A (Feb 12, 1994) ("Many on-line romances ... have resulted in conventional marriages.").

${ }_{222}$ For instance, scholars may participate in academic discussion groups, making comments that enhance their own reputation and that of their university.

${ }^{223}$ Some might argue that since these links use telephone lines they benefit from at least one government regulation-the requirement that telephone companies be common carriers. See Communications Act of 1934, 47 USC §§ 201-02 (1988 \& Supp 1993) (requir- 
In fact, computer nets have also structured themselves to create new mechanisms that facilitate the exchange of information. Discussion groups, for instance, in staking out portions of cyberspace for a particular topic, increase the value of information transmission rights by gathering the appropriate audience for particular exchanges of opinions and ideas. If I want to expand my ideas about difference feminism or Civil War battles on the street, in the faculty lounge, or even in a general circulation newspaper, I am likely to miss many interested listeners. Discussion groups give speaker and potential audience a more efficient way of finding one another.

Indeed, one of the more celebrated controversies in the Internet's history-sparked appropriately enough by a lawyer-powerfully demonstrates the use value of information and the amenability of cyberspace to property-rights analysis. In April 1994, a lawyer from Phoenix irritated Internet users around the world by putting advertisements on a large number of special-subject discussion groups. ${ }^{224}$ While he claimed that his action was wholly legal, ${ }^{225}$ under a property-rights paradigm it can be understood as the first publicized prototrespass in cyberspace, with the lawyer playing the role of the snake in the Garden of Eden. By staking out a particular area of cyberspace for a particular use (we may call such spaces "cyberfiefs"), the creators of a discussion group should gain ownership of the space, including the classic hallmark of ownership-the right to exclude others. ${ }^{226}$ Certainly, assigning ownership rights to those

ing telephone companies to provide service to all comers without discrimination). Under the property-rights theory offered here, such regulation may once have been justified when telephony was a natural monopoly. Similar service requirements are imposed on natural monopolies constituted by material property not used for the purpose of information transmission, such as utilities. It is certainly true that the common carriage requirement was historically not subject to First Amendment challenge. See Cate, 30 Wake Forest $L$ Rev at 20-24 (cited in note 22). Now, the conditions that made telephony a natural monopoly are disappearing and the common carrier requirements may themselves become subject to First Amendment attack. Id at 24. For further discussion of the technological changes that permit digital information to be transmitted in a variety of ways and render telephony only one of several competitors for such communication, see text accompanying notes $250-58$.

${ }_{224}$ Peter H. Lewis, An Ad (Gasp!) in Cyberspace: Lawyer's Message Violates Netiquette', NY Times D1 (Apr 19, 1994).

225 Id at D2.

225 It might be thought that the ownership rights should belong to the Internet provider that sells time on the Internet to the creator of the discussion group. But even if these rights were nominally assigned to the provider, we would expect them to be effectively exercised by the creator because they are more valuable to the creator. See R.H. Coase, The Problem of Social Cost, 3 J L \& Econ 1, 15-16 (1960) (in the absence of transaction 
who create discussion groups is consistent with the famous Lockean proviso that those wishing to assert a property claim over matter they have transformed by their labor should leave "enough and as good" for others. ${ }^{27}$ Being infinitely expandable, cyberspace satisfies the proviso as well as anything known to man. ${ }^{228}$

The advertisement was a prototrespass or protoconversion insofar as the lawyer entered a part of cyberspace that others had dedicated to a particular use incompatible with that of the trespasser. ${ }^{229}$ The lawyer was at liberty to set up a discussion group for ambulance chasing, but chose instead to free-ride on others' efforts. ${ }^{230}$ In doing so he reduced the value of the cyberspace that he violated: potential users would be deterred

costs, rights will gravitate to highest valuing user). The creator is a higher-valuing user because he knows better than the Internet provider what rules will maximize the value of his cyberfief.

Of course, cyberfief owners are under no compulsion to establish rules that will facilitate their right of exclusion. Many discussion groups, particularly in the Arcadian days of the Internet, were open to all kinds of messages and depended on custom and etiquette to preserve the value of the space. As the Internet community becomes more numerous and less tightly knit, law is likely to become more necessary to preserve value.

${ }^{227}$ For discussion of the Lockean proviso, see text accompanying notes 80-83.

${ }^{228}$ Under this view we may see cyberspace as a place where, at least for the purposes of information exchange, we may create the kind of utopias that philosopher Robert Nozick conceives:

Every rational creature in this world you have imagined will have the same rights of imagining a possible world ... as you have. The other inhabitants of the world you have imagined may choose to stay in the world which has been created for them ... or they may choose to leave it and inhabit a world of their own imagining. If they choose to leave your world ... your world is without them. You may choose to abandon your imagined world, now without its emigrants. This process goes on; worlds are created, people leave them, create new worlds, and so on.

Nozick, Anarchy, State, and Utopia at 299 (cited in note 82) (footnote omitted). As Nozick points out, to create stable worlds the creator cannot act like an absolute monarch and exploit the other inhabitants, or they will leave. Id at 300 . So it will be with cyberfiefs: those who create them will have to consider the other participants' interests in the framing of the cyberfief's rules if they want to have a vibrant and valuable space.

${ }_{223}$ Cyberfief owners can establish the rules that will regulate their bit of cyberspace in a variety of ways. They may assign their rights to another group that will actively monitor the discussion group. (They may also issue discussion group charters establishing decision procedures in advance: such charters could increase the value of that particular piece of cyberspace.) Of course, most of the time such rules will not need to be invoked since users of discussion groups can be expected to make a good faith effort to stay within the confines of the topic.

${ }^{230}$ The unearned advantage the lawyer obtained was the attention of devotees of the particular discussion group who momentarily looked at his message because the creators of the discussion group had engendered expectations that the space would be used for a particular subject. 
from connecting to a particular discussion group due to the clutter of messages on unrelated topics.

At first, the reaction of other users of the affected discussion groups was the classic reaction of property owners (and those who benefit from a fledgling system of property rights) before a centralized system for enforcing property rights has been established: they engaged in self-help. ${ }^{231}$ They sent so many messages to the offending lawyer (in cyberspeak they "flamed" him) that his e-mail systems became useless. ${ }^{232}$ Such encroachments on cyberspace property rights may be punished by the law just as trespasses on real property and conversions of personal property were punished at common law. ${ }^{233}$ In punishing such transgressions, government would not make substantive rules for a particular bit of cyberspace: it would merely enforce the rules that the owners made known as the rules of their cyberfief. ${ }^{234}$ These government enforcement mechanisms would be general in scope, and thus would carry little risk of government interference with the right to produce ideas and transmit them over the Internet. ${ }^{235}$ The government's role thus can be limited to provid-

${ }^{2 * 1}$ See Douglas Ivor Brandon, et al, Self-Help: Extrajudicial Rights, Privileges and Remedies in Contemporary American Society, 37 Vand L Rev 845, 850 (1984) (discussing self-help as the progenitor of our legal system).

${ }_{232}$ See Lewis, An Ad (Gasp!) in Cyberspace, NY Times at D1 (cited in note 224).

${ }_{223}$ The hallmark of the common law is its ability to adapt established principles to new situations. See Oliver Wendell Holmes, Law in Science and Science in Law, 12 Harv L Rev 443, 447-51 (1899) (using the term "integration" to describe the internal logic of the common law as it expands to address new situations).

Private advertising firms are already establishing guidelines for advertising on the Internet. See Lawrence M. Fisher, Advertising, NY Times D16 (Aug 3, 1994) (reporting statement of executive at the advertising firm of Ogilvy and Mather that advertising should appear only in lists and groups designated for that purpose).

204 Thus, the substantive rules for cyberspace should not be established by the government but by those who own the cyberfief. The best alternatives to government regulation, however, are not uniform model agreements reached by major Internet providers. See Robert L. Dunne, Deterring Unauthorized Access to Computers: Controlling Behavior in Cyberspace Through a Contract Law Paradigm, 35 Jurimetrics 1, 12-13 (1994) (suggesting model agreement approach). This would replace tyranny by government with tyranny by monopoly. See Mark A. Lemley, Shrinkwraps in Cyberspace, 35 Jurimetrics 311, 321 (1995). The natural process of competition among Internet providers should instead devolve such authority to owners of cyberfiefs. Since customized rules increase the value of particular cyberfiefs to their creators and users, cyberfief creators and users would then be willing to pay more to the Internet providers who permitted the decentralized creation of rules. So long as there is competition, decentralized rules will be in the interest of both providers and users.

${ }_{205}$ Compare Madsen $v$ Women's Health Center, Inc., 114 S Ct 2516, 2538 (1994) (Scalia concurring in part and dissenting in part) (Statutes targeted at speech in specific areas, such as labor relations or abortion, or injunctions extending only to such specific areas, pose dangers to the First Amendment.). 
ing more efficient enforcement for property rights of those who own various parts of cyberspace, thereby increasing the value of information to individuals who produce it. ${ }^{236}$

Issues of censorship have also arisen on the Internet. Prodigy, the largest commercial interconnecting system, has recently developed "George Carlin" software to excise offensive words sent to the users of their network. ${ }^{237}$ Such acts have raised questions about whether the government should itself regulate the Internet in order to protect speech. ${ }^{238}$ Viewing the Internet through the prism of spontaneous order raises doubts about the need for governmental intervention in the decisions of networks about what to permit on their own nets. ${ }^{239}$ Under the property theory offered here, Prodigy has a right to censor its network but its consumers have a right to take their business elsewhere. Since there is no centralized censor exercising the sovereign power of the state, paths will spontaneously arise to carry information with substantial use value. ${ }^{240}$

${ }^{236}$ Allowing private individuals to set the rules for their cyberfiefs may solve a variety of problems other than trespass. For instance, one vexing problem is the question of to what extent members of a discussion group may further disseminate messages sent to that group. See I. Trotter Hardy, The Proper Legal Regime for "Cyberspace", 55 U Pitt L Rev 993, 999 (1994). A property-based theory suggests that the owner of the relevant cyberfief may establish rules to decide such questions. There is no reason for government to impose a centralized solution.

${ }_{237}$ Peter H. Lewis, No More 'Anything Goes': Cyberspace Gets Censors, NY Times A1 (June 29, 1994).

233 Id at D5.

${ }^{239}$ Of course, any decision by the government itself to censor speech should be subject to First Amendment scrutiny. While this is not the place to detail how a property-based jurisprudence might address the many proposals to restrict pornography or indecency on the Internet, a few elements of such an analysis can be sketched. Consider a hypothetical federal proposal that would prohibit all "indecent information" from being circulated on the Internet, for fear that children could access it. In considering this bill, one would want to analyze restrictions on other material property where indecent information is present. For instance, bookstores are not currently banned by federal law from displaying indecent material. While the presence of indecency and pornography on the Internet may force parents to supervise their children's choices of what information they access, the availability of printed indecent material already forces adults to supervise what their children read. Moreover, the end-user computer capabilities of the Internet allow the parent actively to select what will be received through his computer. See notes 248-52 and accompanying text. Since competition will provide incentives to Internet access services to facilitate enduser control with blocking services, parents (even without the aid of government regulation) should be able to control their children's access to material from the Internet even more effectively than they currently control their children's access to printed material.

${ }^{240}$ The reasons that private censorship is unlikely to succeed given current developments in information technology are lucidly set forth in Eugene Volokh, Cheap Speech and What It Will Do, 104 Yale L J 1805, 1836-38 (1995). For discussion of why a single transmission link is unlikely to gain monopoly power, see text accompanying notes 25457. 
The original Internet principle that all information should be free of charge would inhibit some transmission of beneficial information. ${ }^{241}$ Some information will be transmitted only if users are willing to pay for it specifically. But this "free information" principle is not inherent in the notion of a network or of a property-rights approach to speech, and is now being relaxed. ${ }^{242}$ There is no reason that particular information on computer nets cannot be made available only to those who pay. ${ }^{243}$ For instance, newspapers can set up services providing supplemental information to their subscribers. ${ }^{244}$ So long as the government does not prevent commercial use of computer nets, there is every reason to expect that the exercise of property rights in information transmission will assure that the net will continue to put its decentralized, low-cost information system to a growing multiplicity of uses that reflect the multifarious interests of individuals. ${ }^{245}$

\section{B. Property and the Expanding Net versus Turner}

While the print press, broadcasting, and cable television are today vibrant and largely distinct enterprises from the computer networks that gave rise to the Internet, they are converging into a system that will resemble computer nets in its decentralized and spontaneous order. The principal difference will be that computer nets of the future will facilitate the transmission of information not only in textual form, but in multimedia form, including sound and video. The reason for the convergence of transmitters of multimedia into a netlike system is the digital revolution in telecommunications. All information can be translated into a digital form called "bits." ${ }^{246}$ The information can then be

241 Elmer-Dewitt, Battle for the Soul, Time at 53 (cited in note 216). This principle was the result of the continuing involvement of the government in the Internet: the National Science Foundation did not wish to subsidize commercial use. See Burk, 68 Tulane L Rev at 15 (cited in note 212).

${ }_{242}$ See Anne Wells Branscomb, Anonymity, Autonomy, and Accountability: Challenges to the First Amendment in Cyberspaces, 104 Yale L J 1639, 1657 \& n 65 (1995).

${ }_{243}$ For instance, information may be provided only to those who have a password to access it. Information can also be released only upon payment with "digital" cash. For a discussion of digital cash, see A. Michael Froomkin, The Metaphor Is the Key: Cryptography, the Clipper Chip, and the Constitution, 143 U Pa L Rev 709, 720 (1995).

244 News stories may thus become windows into far more comprehensive and complex bites of information compiled by reporters for the interested reader.

${ }^{245}$ One complex issue that the Internet will have to face as it expands is a more complex pricing and metering system. For a discussion of these issues, see The Internet: Freeloading as a Way of Life 9, 12, in The Economist at 50 (July 1-7, 1995).

${ }^{245}$ See Nicholas Negroponte, being digital 11-17 (Knopf 1995) (explaining bits as the 
transmitted electronically at the speed of light. ${ }^{247}$ When a bit of information is transmitted electronically, computers can select and rearrange the information at the point of reception. ${ }^{248}$ The "declining cost of computing has permitted the processing and storage of information to become more decentralized, thus enabling the intelligence in the telecommunications network to reside ... in the dispersed customer premise equipment of ultimate consumers rather than with some central provider of switching and transport."249 The intelligence that edits and selects information for our consumption no longer has to reside entirely at the point of transmission, as it does now in the editorial staff of a newspaper or the programming manager of a broadcaster. The individual can become his own program director and editor by programming his computer to retrieve particular information from the nets to which he is linked. The result is substantial decentralization of control over the information that is transmitted over computer nets.

Further, digital technology is providing more and more opportunities for different kinds of broad-bandwidth network providers of video services to compete. ${ }^{250}$ Conventional television broadcasters and cable are now being supplemented by microwave and satellite broadcasting ${ }^{251}$ and even phone lines. ${ }^{252}$ This multifarious delivery of information means increased competition:

"smallest atomic element in the DNA of information").

247 Id at 14.

${ }^{248}$ Id at 19-20 (discussing rise of intelligence at the point of reception of information rather than at the point of transmission).

${ }_{249}$ J. Gregory Sidak, Telecommunications in Jericho, 81 Cal L Rev 1209, 1209-10 (1993), reviewing Michael K. Kellogg, John Thorne, and Peter W. Huber, Federal Telecommunications Law (Little, Brown 1992) and Peter W. Huber, Michael K. Kellogg, and John Thorne, The Geodesic Network II: 1993 Report on Competition in the Telephone Industry (Geodesic 1992).

${ }^{250}$ Bandwidth has been described as "the capacity to move information down a given channel." Negroponte, being digital at 22 (cited in note 246).

251 For instance, Bill Gates, the chairman of Microsoft, and Craig McCaw, the chairman of McCaw Cellular, have established Teledesic, a "network of 840 satellites that would provide wireless voice, data, and video transmission to any point on the globe." James Fallows, Networking, Atlantic Monthly 34, 36 (July 1994). At the other end of the stratosphere, the company Metricom plans to create local networks by hanging low power transmitters on light and telephone poles. Id. Many of these media are now also being improved by digital compression, which permits, for instance, as many as ten television signals "to fit into the bandwidth that previously had been occupied by one." Sidak, $81 \mathrm{Cal}$ L Rev at 1209 (cited in note 249).

252 Unfortunately Congress has restricted the ability of the telephone companies to offer certain information services. See text accompanying notes 281-87. 
With digitalization all of the media become translatable into each other-computer bits migrate merrily-and they escape from their traditional means of transmission. A movie, phone call, letter, or magazine article may be sent digitally via phone line, coaxial cable, fiberoptic cable, microwave, satellite, the broadcast air, or a physical storage medium such as tape or disk. ${ }^{253}$

As the leading treatise on telecommunications law observes, any market power previously possessed by the providers of information services is disappearing; this is due to the competition brought about by convergence of many previously distinct methods of transmission into a single market for the transmission of digital information. ${ }^{254}$ Contrary to the claims of those favoring government regulation of telecommunication, there is little risk of a "bottleneck" in the modes of transmission that would inhibit consumers from enjoying the information services they want. ${ }^{255}$

This new cornucopia of modes of transmission dissolves the one possible justification for special regulation of the material property used for transmission of information. Under the Madisonian First Amendment, regulation of the means of transmission might be justified when the material property for transmission is so scarce that its use by one transmitter fails to leave opportunity for others to transmit information. ${ }^{256}$ Today, the

253 Stewart Brand, The Media Lab 18 (Penguin 1988).

${ }^{254}$ See Michael K. Kellogg, John Thorne, and Peter W. Huber, Federal Telecommunications Law $\S 3.8$ at 187 (Little, Brown 1992). What monopoly power exists generally derives from exclusive rights over messages that are protected by copyright. Id.

255 Id. Even the seemingly most entrenched communications monopolies are losing their power. For instance, local exchange service will soon encompass not only traditional telephony, but also new competitors such as "cellular radio, radio-based personal communication services, wireless LAN's, [and] cable television." See William R. Malone, Book Review, 45 Fed Comm L J 333, 337 (1993), reviewing Michael K. Kellogg, John Thorne, and Peter W. Huber, Federal Telecommunications Law (Little, Brown 1992), Peter W. Huber, Michael K. Kellogg, and John Thorne, The Geodesic Network II: 1993 Report on Competition in the Telephone Industry (Geodesic 1992), and Daniel L. Brenner, Law and Regula. tion of Common Carriers in the Communications Industry (Westview 1992).

${ }_{256}$ For discussion, see text accompanying notes 208-09. The question of whether the Lockean proviso is ever completely satisfied, given physical scarcity, is a much debated one. I agree with Geoffrey Miller, who believes that one must interpret the Lockean proviso consistently with sustaining a state with very robust private property rights, because vindicating such a state was Locke's rationale for writing Two Treatises. See Geoffrey P. Miller, Economic Efficiency and the Lockean Proviso, 10 Harv J L \& Pub Policy 401, 406 (1987) ("The problem for interpreting the Lockean Proviso therefore resolves itself into a matter of determining how, under conditions of scarcity and trade, the Proviso can limit the enclosure of resources from the commons without undermining the basic purposes of private property."). The proper interpretation must give weight to the 
opportunities for transmission through the expanding net will be much greater than those afforded, now or ever before, by print media. ${ }^{257}$ Because the outlets for video programming allow at least as much opportunity for transmittal of information as the outlets for print did in Madison's time, it is fair to conclude that private and unregulated ownership satisfies the Lockean proviso at least to the degree that print media satisfied the proviso at the time Madison drafted the First Amendment. ${ }^{258}$

The Court's most recent decision in the telecommunications area-Turner Broadcasting System, Inc. v FCC ${ }^{259}$-was in error precisely because it failed to apply the logic of a property-cen-

familiar social considerations favoring private property, such as efficiency and decentralization of power, see Nozick, Anarchy, State, and Utopia at 176-77 (cited in note 82), permitting the Lockean proviso to be satisfied even though there is a limited supply of goods in the common. At least some of these considerations (such as decentralization) are weakened when there is acute physical scarcity or a natural monopoly, and thus greater regulation may be justified in such unusual cases.

For an interesting argument that the Lockean proviso is always satisfied in an advanced market economy that provides infinite ways of accumulating capital, thus making it possible to buy even the scarcest goods, see Rapaczynski, Nature and Politics at 208-11 (cited in note 76).

257 Today only 24 out of 1,516 U.S. localities are served by two or more unaffiliated local daily newspapers. Kellogg, Thorne, and Huber, Federal Telecommunications Law \& 3.8.2 at $189 \mathrm{n} 11$ (cited in note 254). The scarcity rationale for regulation of transmission is far stronger in the newspaper context than in the video programming market.

All physical goods, including newsprint, are scarce. From a standpoint of pure economic efficiency, scarcity does not justify regulating broadcasting any more than it justifies regulating newsprint. See R.H. Coase, The Federal Communications Commission, $2 \mathrm{~J} \mathrm{~L} \&$ Econ 1, 14 (1959). But as discussed above, see note 256, considerations other than efficiency may determine whether Lockean rights theory is satisfied by a particular system of property rights. Scarcity may thus still be a relevant consideration in justifying a regulation.

${ }^{258}$ I recognize the powerful argument that government regulation of broadcasting's content was never justified because the First Amendment views the government as the overwhelming danger to free speech, even if private appropriation of the speech transmitting property arguably does not satisfy the Lockean proviso. See Message to the Senate Returning Without Approval the Fairness in Broadcasting Bill, 1987 Pub Papers 690-91 ("History has shown that the dangers of an overly timid or biased press cannot be averted through bureaucratic regulation, but only through the freedom and competition that the First Amendment sought to guarantee."). My point here is simply that even on a reading of the Speech and Press Clauses that is faithful to their roots in Lockean property rights, including the proviso, special regulation of the video communication media can no longer be justified.

In Turner Broadcasting System, Inc. v FCC, Justice O'Connor shares the spirit, if not the letter, of these arguments. See 114 S Ct 2445, 2480 (1994) (O'Connor concurring in part and dissenting in part) ("But the First Amendment as we understand it today rests on the premise that it is government power, rather than private power, that is the main threat to free expression; and as a consequence, the Amendment imposes substantial limitations on the Government even when it is trying to serve concededly praiseworthy goals.").

259114 S Ct 2445 (1994). 
tered understanding of the First Amendment to the emerging modern means of multimedia communication. At issue in Turner was the constitutionality of must-carry rules that Congress had applied to the broadcasting industry. These rules, peculiar to the video communications industry, require cable operators to assign essentially one-third of their stations to local commercial broadcasters and local noncommercial educational broadcasters. ${ }^{260}$ Declining to apply strict scrutiny to the provisions because they were not content based, the Court did not invalidate the rules. ${ }^{261}$ On the assumption that the provisions were content neutral, the Court instead applied the $O^{\prime} B r i e n$ test, ${ }^{262}$ which requires the government to show that the restrictions on First Amendment freedoms were supported by a substantial interest and that they were no more restrictive than necessary to further that interest. ${ }^{263}$ The Turner Court thus remanded the case to the lower courts with instructions to review the provisions under this standard, while affording substantial deference to Congress's factual findings on the nature of the interest at stake-in this case, maintaining the viability of the broadcast industry. ${ }^{264}$

The Court correctly recognized that cable was not subject to the conditions of physical scarcity that it had previously held justified special regulation of the broadcast spectrum. ${ }^{265}$ Thus,

2єa See The Cable Television Consumer Protection and Competition Act of $1992 \$ \$ 4-5$, Pub L No 102-385, 106 Stat 1460, 1471-81, codified at 47 USC $\$ \S 534-35$ (1988 \& Supp 1993). The Act mandates that all cable operators with more than twelve channels carry the signals of licensed "local" commercial broadcast television stations whose signals are received over-the-air in the same television market as cable. The cable operator is not required to fill up more than one-third of its channels with such broadcasters, but if there are not enough broadcasters to meet its one-third quota, the operator must carry the signals of one or two low-power stations. Section 5 of the Act requires cable operators with more than thirty-six channels to carry the signal of every noncommercial educational broadcast station unless the programming substantially duplicates that of a station already carried. Systems with fewer than thirty-six channels must carry between one and three educational broadcasters. For further description of the intricacies of the must-carry rules, see Turner Broadcasting System, Inc. v FCC, 819 F Supp 32, 36-37 (D DC 1993).

201 Turner, 114 S Ct at 2458-72.

${ }^{202}$ The test formulated in $O^{\prime} B r i e n$, permits a content-neutral regulation affecting speech if the regulation:

furthers an important or substantial governmental interest; if the governmental interest is unrelated to the suppression of free expression; and if the incidental restriction on alleged First Amendment freedoms is no greater than is essential to the furtherance of that interest.

391 US at 377.

${ }_{263}$ Turner, $114 \mathrm{~S}$ Ct at 2469.

264 Id at 2471-72.

2क Id at 2456-57. The scarcity rationale for regulation of the broadcast spectrum was 
it held that cable television enjoyed greater First Amendment protection than the protection previously afforded broadcasting, although the Court was vague as to the degree of additional protection. ${ }^{266}$ Under the property-based view of the First Amendment, however, once the Court had concluded that the multimedia communications market of which cable is part was not subject to peculiar conditions of scarcity, it should have invalidated the must-carry requirements on the simple ground that these were rules of a kind not generally applicable to business enterprises. Given that scarcity in this market is no more severe than in the print press, there is no justification for Congress to apply any rules to communications technology beyond those rules generally applicable to all businesses, such as antitrust, securities, and labor laws. ${ }^{267}$ Certainly, it is unusual for business reg-

first noted in Red Lion Broadcasting Co. v FCC, 395 US 367, 396-401 (1969). At issue in Red Lion was the constitutionality of the so-called fairness doctrine. The fairness doctrine required that broadcasters provide fair coverage of opposing viewpoints on controversial issues of public importance. The Court upheld this regulation in part because of the physical scarcity of the electromagnetic spectrum. Id at 388-89, 396-401. For an excellent discussion of the dramatic difference between the "broadcast model" of the First Amendment and the "print model," see Thomas G. Krattenmaker and L.A. Powe, Jr., Converging First Amendment Principles for Converging Communications Media, 104 Yale L J 1719, 1719-24 (1995).

${ }^{266}$ Turner, $114 \mathrm{~S}$ Ct at 2457. Even in its discussion of scarcity, Turner displays the incoherence characteristic of opinions negotiated for a narrow majority. The Court thus left somewhat opaque whether cable was to be regulated under the same standards as print or under some third standard all its own. Id at 2457 (suggesting that "settled principles of [ ] First Amendment jurisprudence" should be applied to cable, but that cable's "unique physical characteristics" should also be taken into account). Nevertheless, the Court did seem to conclude that the severe scarcity that it felt had characterized broadcast television outlets in the past simply did not apply to cable.

The Court also failed to modify its previous First Amendment standard for broadcasting despite the fact that its announcement of a different standard for cable seems to undermine fatally the scarcity rationale underlying the lesser degree of protection for broadcasting. The Court stated that "[a]lthough courts and commentators have criticized the scarcity rationale since its inception, we have declined to question its continuing validity as support for our broadcast jurisprudence, and see no reason to do so here." Id (footnotes and citations omitted) (emphasis added). It is difficult, however, to understand how broadcasting can be evaluated in the future under wholly distinct First Amendment standards from that of cable. Cable and broadcasting are competitors in the market for live home video programming. Resources for such transmission that are not scarce in a constitutional sense when cable alone is at issue cannot become scarce when broadcasting is added to the market.

${ }_{267}$ Sidak argues on the basis of somewhat different First Amendment reasons that the FCC should interpret its public interest mandate as requiring no more than that telecommunication companies comply with the antitrust laws. See Sidak, $81 \mathrm{Cal} L$ Rev at 1234-38 (cited in note 249). See also Cate, 30 Wake Forest L Rev at 46-47 (cited in note 22) (noting that antitrust is available to protect against natural monopoly).

Under my view, the broadcast industry would be able to challenge cable operators' alleged bottleneck on consumers' access to home video programming under antitrust 
ulations to require businesses to help their competitors, as cable was required to maintain the viability of broadcasting. ${ }^{268}$ Turner thus dramatically displays the difference between current jurisprudence and a property-centered jurisprudence of the First Amendment in the analysis of government regulations of privately owned media of communication.

Turner itself also shows why the property-based interpretation of the First Amendment is necessary to protect communication media from government interference. ${ }^{269}$ After concluding that cable should receive substantial First Amendment protection, the Court agreed that the rules should be invalidated if they were content based because then the government would be trying to skew the market for communications. ${ }^{270}$ The application of the traditional content-based inquiry, however, was not sufficient to prevent such skewing. First, as the Court admitted, distinguishing between content-based and content-neutral regimes is not simple. ${ }^{271}$ The difficulty of the task will lead courts to make mistakes. In Turner, the Court in fact made such a mistake. It failed to recognize that because local broadcasters operated under a public interest regime that required them to provide local issues programming, and cable did not, the contents of broadcast

rationales that seek to maximize consumer welfare. The Court has consistently rejected the notion that the press is exempt from antitrust laws. See Lorain Journal Co. $v$ United States, 342 US 143, 155-56 (1951) (The First Amendment permits Congress to "appl[y] to a publisher what the law applies to others."). Indeed one relevant antitrust concept-the essential facilities doctrine-was established in the press context. See Associated Press $v$ United States, 326 US 1, 19-20 (1945). For reasons suggested below, see text accompanying notes $280-86$, I find unpersuasive the broadcasters' arguments that cable is inhibiting, in a manner that harms consumer welfare, their ability to compete. Accordingly, I believe their antitrust claims would likely fail.

2a For discussion of why the First Amendment requires the application of regulations no more restrictive than the norm applied to similar material property, see text accompanying notes $179-81$.

269 The application of the Press Clause to modern means of communication is not at all difficult for an originalist. See Judge Bork's concurring opinion in Ollman $v$ Evans:

In a case like this, it is the task of the judge in this generation to discern how the framers' values, defined in the context of the world they knew, apply to the world we know. The world changes in which unchanging values find their application. The fourth amendment was framed by men who did not foresee electronic surveillance. But that does not make it wrong for judges to apply the central value of that amendment to electronic invasions of personal privacy.

750 F2d 970, 995 (DC Cir 1984) (Bork concurring).

"7o Turner, $114 \mathrm{~S} \mathrm{Ct}$ at 2458.

271 Id at 2459 . 
and cable programming were distinct as a matter of law. ${ }^{272}$ Therefore, the regulation was indeed content based.

More fundamentally, the content-based test, as applied by the Court, does not screen for all the manipulations of speech that the property-based interpretation prevents. Special rules targeted at the operations or structure of the communication media inevitably affect content, even if they do not expressly refer to it. Once again, Turner provides an instructive example. Broadcasting, unlike cable, does not charge viewers for programs. Of course, so-called "free television" is not free, but captures its revenues wholly from advertisements or, in the case of public television, from government or charitable subventions. ${ }^{273}$ How an enterprise is financed obviously will have an effect on the audience it seeks and on the content of the programs it televises. For instance, commercial broadcasters would put a premium on reaching the largest possible audience of those people not reached by other advertising media, such as those who do not read newspapers or newsmagazines. The predictable result is down-market programs that appeal to the lowest common denominator. ${ }^{274}$ Only restrictions on Congress's ability to create special rules for the structure of the communications industry will prevent Congress from determining how information is transmitted, and, as a result, what information is transmitted.

Moreover, Turner's application of the current First Amendment test for non-content-based restrictions-the O'Brien test-also shows its inadequacy in protecting speech. O'Brien requires the courts to weigh the substantiality of the interest as defined by the government (in this case Congress) against the restriction on First Amendment freedoms after giving substantial deference to Congress's judgment. ${ }^{275}$ Public choice theory casts doubt on the wisdom of deferring to Congress in this context. It would predict that the more established firms in the video communications industry-in this case, the broadcast sector-will

${ }^{272}$ This point is thoroughly discussed in Turner, $819 \mathrm{~F}$ Supp at 57-59 (Williams dissenting). Other strong arguments that the must-carry rules were content based need not be repeated here. See Turner, $114 \mathrm{~S}$ Ct at 2476-79 (O'Connor concurring in part and dissenting in part).

${ }^{273}$ The Court accepted the characterization of broadcasting as free. See Turner, $114 \mathrm{~S}$ Ct at 2469.

${ }_{274}$ A similar point in a different context is made in Murray N. Rothbard, For a New Liberty 111-12 (Macmillan 1973) (noting the effect of broadcasting's revenue structure on the programs it produces).

${ }_{275}$ Turner, $114 \mathrm{~S} \mathrm{Ct}$ at 2469-72 (applying O'Brien test). For a discussion of O'Brien, see notes 196-202 and accompanying text. 
use their resources, shareholders, and employees to influence the legislature disproportionately. ${ }^{276}$ Public choice theory also suggests that politicians will favor broadcasters over other companies because the regulatory licensing scheme that controls broadcasters gives politicians greater influence over the content of broadcast materials as compared with other modes of transmission. ${ }^{277}$ Thus, legislators will be more likely to accept the broadcasting industry's arguments about optimal competition and industry structure, regardless of their merit, and to dress up in the most neutral-sounding terms the broadcasting industry's attempt to preserve market share against new competitors.

This may well have occurred in the enactment of must-carry rules. Congress accepted the broadcast industry's weak argument that consumer welfare would be harmed in the absence of the must-carry rules. Broadcasters argued that the cable operators would have a bottleneck over programming and would discriminate against the broadcasters' programming in favor of their own. Consumers would be denied programming that they wanted. ${ }^{278}$ These arguments are weak on their own terms. First, cable operators have an interest in transmitting broadcasters with popular programming. ${ }^{279}$ Moreover, in most areas, an inexpensive $A / B$ switch would allow a consumer to change by remote control from cable to broadcasting, thus providing easy access to broadcasts that are not carried on cable. ${ }^{280}$ Of course, consumers might not purchase an $\mathrm{A} / \mathrm{B}$ switch even in response to broadcasters' advertisements about its availability. Such a response would suggest that consumers were not particularly inter-

236 See Farber and Frickey, Law and Public Choice at 23-24 (cited in note 18) (discussing the reasons concentrated interests exert disproportionate influence).

277 See Matthew L. Spitzer, The Constitutionality of Licensing Broadcasters, 64 NYU L Rev 990, 1054 (1989) (discussing influence of politicians on the distribution of broadcasting licenses).

${ }_{278}$ See Cable TV Consumer Protection Act of 1991, Hearings on S12 before the Subcommittee on Communications of the Senate Committee on Commerce, Science, and Transportation, 102d Cong, 1st Sess 217-21 (1991) ("Cable TV Hearings") (statement of James B. Hedlund, President, Association of Independent Television Stations, Inc.).

279 See id at 255 (colloquy between Senator Packwood and Edward O. Fritts, President of the National Association of Broadcasters, in which Fritts does not deny that cable operators would run popular broadcasters).

2s: See Even If VCR's in the Den, You Can Watch in the Bedroom, Columbus Dispatch 7H (June 4, 1994) (new model TVs have A/B switch, and switches can be added to old models for less than ten dollars); Cable TV Hearings at 256 (cited in note 278) (response of James B. Hedlund, President, Association of Independent Television Stations, Inc., conceding that $\mathrm{A} / \mathrm{B}$ switches are technically possible in areas other than those, such as Manhattan, where there is widespread interference). 
ested in what local broadcasters not already carried by cable had to offer.

Congress's imposition of the must-carry rules in the 1992 Cable Act is flawed for an even more obvious reason: Congress rejected arguments made by the government's own expert agency to include provisions increasing opportunities for broadcast signals to be carried over wire systems other than cable. Despite the recommendations of the FCC, ${ }^{281}$ Congress did not relax provisions of the 1984 Cable Act that prevented telephone companies from offering television services under their own editorial control to their subscribers. ${ }^{282}$ These so-called cross-ownership regulations insulated cable companies from other companies that were well positioned to offer similar services. ${ }^{283}$ By relaxing such regulation, Congress could have accelerated the process by which other networks, such as fiber optic cables, satellites, or microwave networks of the kind that are emerging in the industry, would arise to carry valuable programming that cable refused to carry. ${ }^{284}$ Because of the narrow focus of the O'Brien test on the effects of the restrictive regulation at issue, Turner never even referred to these preexisting regulations. Ironically, therefore, the Court upheld the must-carry rules on the premise that cable has substantial power over broadcasting, when legislative regulation of alternative media was itself partially responsible for maintaining such power as cable possessed. ${ }^{285}$

${ }^{281}$ In 1988, the FCC tentatively concluded that restrictions on the telephone companies' ability to market their own package of television programming to their subscribers should be relaxed. See Telephone Company-Cable Television Cross-Ownership Rules, Sections 63.54-63.58, 3 FCC Rec 5849, 5851 (July 20, 1988) (Further Notice of Inquiry and Notice of Proposed Rule Making). In 1992, the FCC formally recommended to Congress that it relax the cross-ownership rules. See Telephone Company-Cable Television Cross-Ownership Rules, Sections 63.54-63.58, 7 FCC Rec 5781, 5786-87 (July 16, 1992) (Second Report and Order, Recommendation to Congress, and Second Further Notice of Proposed Rulemaking).

28247 USCA § 533(b)(1)-(2) (1991 \& Supp 1995). This provision was part of the Cable Communications Policy Act of 1984, Pub L No 98-549, 98 Stat 2779, 2785.

${ }_{283}$ Kellogg, Thorne, and Huber, Federal Telecommunications Law $\$ \$ 14.10-14.11$ at 716-19 (cited in note 254).

${ }^{284}$ For discussion of the rise of these networks and how they have decreased the market power of the owners of traditional media of transmission, see text accompanying notes 246-55.

${ }^{285}$ The restrictions on cross-ownership are now under constitutional attack. Fortunately, the courts that have ruled on the challenges have uniformly held that the rules violate the First Amendment. See Chesapeake and Potomac Telephone Co. $v$ United States, 830 F Supp 909, 931-32 (E D Va 1993), aff'd, 42 F3d 181 (4th Cir 1994); US West, Inc. $v$ United States, 855 F Supp 1184, 1193 (W D Wash 1994), aff'd, 48 F3d 1092 (9th Cir 1994); Ameritech Corp v United States, 867 F Supp 721, 737 (N D Ill 1994); BellSouth Corp $v$ United States, 868 F Supp 1335, 1344 (N D Ala 1994); NYNEX Corp v United 
Under current First Amendment jurisprudence, the judiciary thus may fail to catch legislative manipulations of the reasons for regulating information transmission, both because of the complexity of constitutional inquiry and because of the Court's relative institutional incapacity to look behind the factual determinations of Congress. ${ }^{286}$ But judges also will be disposed to give the benefit of the doubt to communication enterprises that represent the status quo for the all-too-human reason that they will be more familiar with the established systems of communication than with new systems: they will likely prefer what they know to what they cannot imagine. Turner's failure to appreciate the expanding computer and telecommunications networks shows that a rule that presumptively prohibits Congress from imposing special rules for different modes of mass communication is particularly important in a period of rapid technological change such as the present.

Indeed, to put Turner in proper perspective, it is instructive to recall an incident from another great period of change. After the French revolution, the Paris Book Guild sent a petition to an important committee chairman in the National Assembly. The petition sought reinstatement of the previously suspended requirement that any book published in France receive the imprimatur of one of the publishers in the booksellers' guild:

We request, sir, that you glance over it and lend all your influence to our demands. From these abuses of the freedom

States, 1994 US Dist LEXIS 20414, *4 (D Me).

205 Public choice theory would suggest that interest groups have an incentive to make use of the judiciary's putative institutional incapacity for fact finding by obtaining factual findings from the legislature that insulate their preferred legislation from constitutional attacks in court. Politicians would likely acquiesce in this strategy. Insofar as the bargain they make with interest groups is less likely to be undone by the courts, they can charge more for the bargain in terms of support and resources from the interest group. For the original discussion of legislation as a bargain between interest groups and legislatures, see William M. Landes and Richard A. Posner, The Independent Judiciary in an InterestGroup Perspective, $18 \mathrm{~J} \mathrm{~L} \&$ Econ 875, 877-83, 888-91 (1975). For a discussion of the degree to which the judiciary will agree to be a faithful agent of these bargains, see Thomas W. Merrill, Pluralism, the Prisoner's Dilemma, and the Behavior of the Independent Judiciary, $88 \mathrm{Nw}$ U L Rev 396 (1993).

The Turner Court may have implicitly recognized the force of the public choice consequences of entirely insulating the factual premises of must-carry legislation from judicial review. The Court required that on remand, the lower court review some of the factual premises on which the must-carry rules rely, such as the claim that these rules are necessary to preserve the viability of broadcasting. Turner, $114 \mathrm{~S} \mathrm{Ct}$ at 2472 . Nevertheless, such review is unlikely to ameliorate substantially the problems described above, if it is done with "substantial deference" to congressional determinations, as the Court suggests. Id at 2471. 
of the press, yet greater abuses have resulted. Countless persons who can barely read have established and maintain shops in every quarter of the capital, hanging over their door their name and the title of Bookseller, which they have no scruple about usurping. We dare to hope, sir, ... the $\mathrm{Na}$ tional Assembly will take the book trade in hand . . . in view of the abuses and thefts as well as the sale of bad books with which France will soon be infected if everyone is free to do business as a bookseller. ${ }^{287}$

In the annals of the history of information transmission, today's argument for special regulation of the telecommunications industry arising from the digital revolution will appear as preposterous as the guild's argument for regulating the low-cost printers that the industrial revolution made possible.

\section{The Promise of Property IN THE INFORMation Age: PROPERTY'S CRITIQUE OF SELF-GOVERNANCE AND SELF- REALIZATION THEORIES OF FREE SPEECH}

The prevailing theories of free speech do not view speech as an individual property right. One popular theory (increasingly so in academic circles) understands free speech as an instrument for promoting a collective good-that of democratic self-government. The other (and probably the reigning theory in the popular imagination) understands free speech as an individual right, but of self-expression rather than of information transmission. In this Section, I suggest that the property-rights conception is a useful correction to the excesses of these other theories. ${ }^{288}$

${ }^{287}$ Plea of Guild of Paris Booksellers, quoted in Carla Hesse, Economic Upheavals in Publishing, in Robert Darnton and Daniel Roche, eds, Revolution in Print: The Press in France, 1775-1800 69, 77-78 (California 1989).

${ }^{28 s}$ The property-rights view has some kinship both metaphorically and actually with what has sometimes been understood as a third view of the First Amendment-the "marketplace of ideas" theory. The theory has venerable roots, originating with Justice Holmes. See Abrams v United States, 250 US 616, 630 (1919) (Holmes dissenting) ("[T]he best test of truth is the power of the thought to get itself accepted in the competition of the market.... That at any rate is the theory of our Constitution."). It is certainly the case that the real Madisonian First Amendment would lead to an unregulated market in ideas. But, unlike the marketplace theory, it is rooted in the natural rights and social contract theory underlying the Constitution. Unlike the marketplace theory, it is not dependent on the empirical claim that the unregulated marketplace is likely to lead to truth and the metaphysical claim that there is an objective truth. The property theory's independence from these claims is important as a matter of theory because the marketplace's empirical and metaphysical premises have been subject to attack. See C. Edwin Baker, Scope of the First Amendment Freedom of Speech, 25 UCLA L Rev 964, 974-81 (1978) 
Of the two, the idea of the First Amendment as a collective right of self-governance has the potential to depart the farthest from the Madisonian view that free speech was one of the principal individual rights to be protected by the social contract. The self-governance rationale for the First Amendment views speech as a means for promoting a particular form of government rather than a fixed object to be protected by government. If speech is essentially a means to another end, the liberties to which we have become accustomed under the First Amendment may be utterly transformed if necessary to reach a collective good defined by others.

The potential for such transformation is now being richly realized by a growing number of theorists in this tradition, such as Owen Fiss, Morton Horwitz, Cass Sunstein, Stephen Gardbaum, and Frederick Schauer. ${ }^{289}$ In one way or another, they all view the exercise of private rights in information transmission as threatening the kind of communication necessary for the flourishing democracy that they believe the First Amendment is designed to ensure. ${ }^{290}$ Their understanding of the First Amendment thus becomes a basis for justifying more regulation

(Marketplace theory must be reconsidered after rejecting its assumption of objective truth.); Jonathan Weinberg, Broadcasting and Speech, 81 Cal L Rev 1101, 1157-64 (1993) (attacking notion that individuals are sufficiently rational for marketplace to lead to truth).

${ }^{2 \times 9}$ For a fuller discussion of the transformation that would occur should the selfgovernance theorists follow their ideas to their logical conclusion, see Martin H. Redish and Gary Lippman, Freedom of Expression and the Civic Republican Revival in Constitutional Theory: The Ominous Implications, $79 \mathrm{Cal} \mathrm{L} \mathrm{Rev} 267$ (1991). For instance, the interest in collective self-determination would lead some current self-governance theorists to prohibit many forms of pornography on the theory that pornography subordinates women and makes it difficult for them to fully participate in the self-governing community. Id at 304-310.

200 Owen Fiss was the first to see that a thorough understanding of free speech as an instrument of democracy may require substantial reworking of First Amendment doctrine. Owen M. Fiss, Free Speech and Social Structure, 71 Iowa L Rev 1405, 1410-21 (1986). See also Owen M. Fiss, Why the State?, 100 Harv L Rev 781, 783 (1987) ("[T] he first amendment does not supply considerations in favor of laissez faire, but rather points toward the necessity of the activist state."). Others were not far behind. See Frederick Schauer, The Political Incidence of the Free Speech Principle, 64 U Colo L Rev 935, 949-57 (1993) (arguing that liberal proposals for government involvement with and regulation of speech are coherent given existing patterns of resource distribution that disadvantage some groups in the "marketplace of ideas"); Morton J. Horwitz, Foreword: The Constitution of Change: Legal Fundamentality Without Fundamentalism, 107 Harv L Rev 30, 109-16 (1993) (proclaiming the need to free the First Amendment from its "Lochnerization" so that "weak political dissidents" can participate in democracy); Stephen A. Gardbaum, Broadcasting, Democracy, and the Market, 82 Georgetown L J 373, 396 (1993) (regulation of public policy information to assure its diversity and quality is a necessary, albeit not sufficient, condition of democracy). 
of speech, changing the First Amendment from a shield against state interference with information transmission rights into a sword that can be wielded on behalf of state control. ${ }^{291}$ Sunstein, for instance, invokes no less an authority than James Madison to claim that the First Amendment requires that government itself play a positive role in supervising systems of information dispersion in order to dispel the civic ignorance that threatens true democracy. ${ }^{292} \mathrm{I}$ have already suggested that the claim that free speech is an instrument for the promotion of selfgovernment stands the real Madisonian First Amendment on its head. ${ }^{293}$ Here I will argue that a property-centered understanding of free speech will be more effective than the self-governance theory in creating an informed citizenry.

The new First Amendment theorists of the collective selfgovernance persuasion point to at least two dangers to democracy that regulation of information transmission may ameliorate. First, citizens do not receive a sufficient diversity of views from the mass media. ${ }^{294}$ Second, because of competitive pressures, the mass media fail to give candidates and public policy advocates uninterrupted time to present their views, but instead engage in "soundbite" journalism and concentrate on the "horse race" aspect of political campaigns. ${ }^{295}$ Accordingly, these theorists suggest that the government should be empowered to require the media both to set aside time for "public affairs" programming that permits more direct access to the views of candi-

291 Professors Sunstein and Horwitz have been quite explicit in calling for a "New Deal for Speech." Sunstein, Democracy and the Problem of Free Speech at 17-51 (cited in note 28); Horwitz, 107 Harv L Rev at 109-16 (cited in note 290). They argue that just as more government regulation was necessary in the 1930 s to promote optimal social welfare, more government regulation of speech is now necessary to promote the optimal dispersion of information in a democratic society. Thus, speech rights are building blocks for a just society rather than constitutive of a just society. Critics have already attacked Sunstein for this reconceptualization, saying that it would work "a radical change in the way we think about the First Amendment." See Neuborne, $62 \mathrm{U}$ Chi L Rev at 423 (cited in note 26 ).

${ }^{292}$ Although Sunstein argues that it is a "Madisonian claim that the First Amendment is associated above all with democratic self-government," see Sunstein, Democracy and the Problem of Free Speech at $\mathrm{xx}$ (cited in note 28), his book never addresses the actual Madisonian claim that speech is a property right.

${ }^{293}$ See Part I.

294 Sunstein, Democracy and the Problem of Free Speech at 56-58 (cited in note 28); Gardbaum, 82 Georgetown L J at 396 (cited in note 290) (discussing the need for the appropriate "range" of opinion for democratic deliberation).

295 Sunstein, Democracy and the Problem of Free Speech at 58-62 (cited in note 28). See also Gardbaum, 82 Georgetown L J at 396 (cited in note 290) (discussing appropriate quality of information necessary for democratic deliberation). 
dates and policymakers, and to assure that this programming reflect "diverse views." 296

Examining the fruits of the spontaneously expanding information networks suggests that the concerns about quality and diversity are misplaced. First, our expanding system of information networks gives our citizens more quality information than ever before. For instance, those who wish can now gain access to uninterrupted speeches of candidates on C-Span and other media. ${ }^{297}$ While it may be true that the network news programs do not provide as much time for candidates' unfiltered speeches as they once did, the networks now often use additional time to analyze campaign positions and explain how those positions advance the candidate's ultimate goal of being elected. ${ }^{298}$ This is useful information because it enables the citizen to discount rationally the likelihood that the politician will keep his promises once elected. Moreover, political science suggests that candidates' substantive positions are strongly influenced by their position in the polls and their standing among specific electoral groups. ${ }^{299}$ Accordingly, the networks' emphasis on the horse race aspects of campaigning is also instructive because it permits citizens to understand politicians' motives and thus better predict their future behavior in office.

Thus, by providing the kind of information that self-governance theorists criticize, mass media actually performs a public service: making some basic notions of the science of public choice available to the public. ${ }^{300}$ Our decentralized information age, with its multiplicity of information sources, permits the understanding of politicians as self-interested utility maximizers provided by public choice to compete with other explanations and predictions of politicians' behavior, including their own speeches. Citizens can then themselves determine which they find more useful. Over time, this kind of information may also reduce the

206 See, for example, Sunstein, Democracy and the Problem of Free Speech at 55-57 (cited in note 28).

297 The Nielsen television ratings service has estimated that 97 percent of citizens now have the option of buying cable. See Paul Kagan Associates, Marketing New Media 2-3 (June 20, 1994) (on file with U Chi L Rev).

$\approx 3$ For extended discussion of this point, see Tom Rosenstiel, Strange Bedfellows: How Television and the Presidential Candidates Changed American Politics, 199264 (Hyperion 1993).

2* The father of all such studies is Anthony Downs, An Economic Theory of Democracy (HarperCollins 1957).

${ }_{300}$ Public choice is "the application of economics to political science." Mueller, Public choice $I I$ at 1 (cited in note 16 ). It views politicians as rational utility maximizers. Id at 2. 
deceptiveness of politicians because the benefits from deception will decline once their promises and maneuvers are explained and appropriately discounted by the public. ${ }^{301}$

Moreover, the property-centered information regime, unlike the regulatory regime of current self-governance theorists, recognizes that the prospect of being entertained is most likely to entice citizens to become informed citizens in the first place. ${ }^{302}$ Like other products, information will have to be attractively packaged to gain a wide audience, and, as with other products, private entrepreneurs are likely to be more successful than government at doing this, even when packaging public policy information. ${ }^{303}$ Indeed, it is remarkable that in the 1992 presidential campaign, all the candidates used entertainment fora, such as late night talk shows, to get their message to the voters. Thus, yet another disadvantage of any government regulation of political information transmission is that it would offer bureaucrats (a group whose previous contributions to human merriment have been largely inadvertent) the opportunity to jettison formats that lure millions of viewers in favor of formats that would please only academics, political junkies, and candidates' close relatives.

The new theorists' arguments for regulation to increase diversity fare no better under a property analysis. They are certainly strangely timed in an age of CNN and C-Span, to say nothing of America Online, where the concerned citizen can spend all of his waking hours engrossed in a wide spectrum of exhaustive public policy expositions, spanning the gamut from the libertarian Cato Institute to the socialist Institute for Policy Studies. ${ }^{304}$ As computer networks become more important in information delivery, even more diversity can be expected: nothing will prevent a discussion group from being established for

${ }^{301}$ Insofar as politicians are rational utility maximizers, they will use deception if it helps them achieve a goal, such as being elected. Insofar as citizens have access to information to monitor the deceptiveness of politicians, deception will be less useful and should decline.

${ }^{302}$ See Posner, 20 Suffolk U L Rev at 23 (cited in note 112).

${ }^{303}$ The reason citizens require their news to be entertaining is that information about collective decisions is unlikely to have very substantial value in advancing their life prospects. See text accompanying notes 316-17. Therefore, to compete with other information reception or other activities that will advance their position more, the news has to present its public affairs programming in an entertaining manner.

${ }^{304}$ Elsewhere I have suggested that many academics on the left favor regulation despite this growth of information sources because of their growing realization that most of the truths emerging from contemporary social inquiry are not hospitable to collectivist and egalitarian ideals. Greater regulation of speech may thus retard competition from these rising ideas. See McGinnis, Commentary at 60 (cited in note 25). 
every shade of political and social opinion and every kind of explication and idea. ${ }^{305}$

A property-rights theorist recognizes that empowering a centralized authority to make decisions as to diversity, particularly under such conditions, will threaten rather than increase the diversity of information. Centralized authorities are unsuccessful at determining the proper prices and quantity of material products to be produced. ${ }^{306}$ There is no reason to believe that they will be better at deciding what proportion of ideas should be transmitted on what pathway of the net.

One response to this argument for laissez-faire information is that because information has many of the characteristics of a public good, too little will be produced without government regulation. ${ }^{307}$ There are several difficulties with this defense of state intervention. ${ }^{308}$ First, in a modern welfare state where the state redistributes rents and where politicians wield enormous power over citizens' lives, there are very substantial incentives for interest groups to produce information that advances their agendas. ${ }^{309}$ If the information that the market fails to produce is defined not as information about public policy that will help individuals take power, but instead as information about public policy that citizens need, how is the state to determine what information is necessary for the citizen? Even where consumer and market goods are at issue, it is difficult for the regulator to determine the information for which the rational consumer would be willing to pay, assuming a perfect market in information. ${ }^{310}$ If

${ }^{305}$ See Charles Fried, The New First Amendment Jurisprudence: A Threat to Liberty, 59 U Chi L Rev 225, 252 (1992) (criticizing First Amendment theorists who want to regulate speech to facilitate democratic deliberation for failing to recognize that more public affairs programming encompassing a wider range of views exists now than ever before).

${ }^{306}$ For the theoretical reasons that centralized planning fails to deliver the goods, see F.A. Hayek, The Use of Knowledge in Society, 35 Am Econ Rev 519 (1945); F.A. Hayek, Competition as a Discovery Procedure, in F.A. Hayek, New Studies in Philosophy, Politics, Economics and the History of Ideas 179 (Chicago 1978).

Of course, government may usefully ban products that represent an imminent threat to life or property, but the new First Amendment democratic theorists are advocating regulation even in the absence of such direct threats.

${ }_{307}$ Sunstein, Democracy and the Problem of Free Speech at 68-71 (cited in note 28); Farber, 105 Harv L Rev at 558-59 (cited in note 30).

${ }^{303}$ See McGinnis, $35 \mathrm{Wm} \&$ Mary $\mathrm{L}$ Rev at $1788-89$ (cited in note 66).

309 See Posner, 20 Suffolk U L Rev at 22 (cited in note 112) (suggesting that public policy information will be produced as an instrument of gaining power). Thus, we should expect that public policy information will be produced in the same ample amounts as advertising.

${ }^{310}$ For a discussion of the argument that regulation can induce a better market in in- 
the product at issue is a health plan or a defense strategy for the entire nation rather than an automobile, it is entirely unclear how even unbiased regulators would create a more perfect market because they would have no principled basis to decide what information citizens needed. .11 $^{31}$

Indeed, the essential rationale for protecting speech gives us reason to be more suspicious of government regulation in the name of creating a public good in information than a material public good like a bridge. ${ }^{312}$ Any state regulation of diversity of any part of the emerging telecommunications and computer networks would inevitably permit the state to exert political influence. ${ }^{313}$ To determine whether a view has been insufficiently represented, the state would have to make fine distinctions. Does the view of a traditional conservative require the response of a libertarian as well as a liberal? What about a socialist? Such assessments would dictate the shape of political discourse if a regime were empowered to promote diversity.

Thus, another advantage of interpreting the First Amendment as a set of property rights of individuals is that such a concept promotes decentralized decision making about the strength of emerging social ideas. It permits the social consensus to be arrived at organically through the decisions of hundreds of mediating institutions such as the press and universities. It will result in the evolution of sentiment, thus minimizing social disturbance. A property-rights regime of speech thus promotes social stability. Ultimately, government regulation probably cannot suppress the replication of those ideas with a competitive advantage any more than jetties can ultimately protect the shoreline from being devoured by the sea. Nevertheless, as with the ultimate destruction of artificial sea barriers, the end result of interfering with the process of information transmission is likely to be more violent.

Making the judiciary rather than the elected branches the arbiter of diversity would not ameliorate the difficulties inherent in assigning any part of such an enterprise to a central decision maker. The judiciary has its own biases, and the assessment of

formation for simple goods, see Robert Pitofsky, Beyond Nader: Consumer Protection and the Regulation of Advertising, 90 Harv L Rev 661, 669-75 (1977).

${ }^{311}$ For another problem with the public-good defense of government intervention, see text accompanying notes 318-19.

${ }^{312}$ For a fuller discussion of this point, see text accompanying notes 102-12.

313 A more detailed explication of some elements of the argument in this paragraph can be found in McGinnis, $35 \mathrm{Wm} \&$ Mary L Rev at 1789-91 (cited in note 66). 
diversity represents precisely the kind of open-ended standard that the judiciary cannot undertake according to neutral principles. ${ }^{314}$ Moreover, the judiciary is no better than the legislature at determining which material products should be produced, and there is no reason to believe that it will be better at determining which ideas should be transmitted.

In short, regulation of information transmission will not even achieve its proclaimed purpose of improving democratic deliberation by promoting a broad public understanding of essential civic issues. The root of self-governance theorists' error is their obliviousness to the brute facts of the world that theorists from the property-rights tradition accept: namely that humans are generally most interested in information that will be useful or entertaining to them, just as they are generally most interested in useful or enjoyable material products. ${ }^{315}$ From this it follows that most citizens will not invest much time or effort in obtaining or listening to public policy information for two mutually reinforcing reasons. First, since the collective decisions will generally have less effect on the individual citizen than his own private decisions, he will rationally invest his scarce time and resources in gathering information about his private enterprises rather than information about the common enterprise of government. $^{316}$ Second, collective decisions will depend on the votes and inputs of thousands, if not millions of others, and thus an individual citizen cannot rationally hope substantially to influence these decisions by better informing himself. ${ }^{317}$ Such ratio-

314 For an argument that the original structure of the Constitution presupposes that the judiciary will act on neutral principles, see John O. McGinnis, The President, the Senate, the Constitution, and the Confirmation Process: A Reply to Professors Strauss and Sunstein, 71 Tex L Rev 633, 665 n 140 (1993).

315 The greatest of all modern defenders of property, Adam Smith, recognized selfinterest as the principal wellspring of human behavior. See Smith, Wealth of Nations at 18 (cited in note 52) ("It is not from the benevolence of the butcher, the brewer, or the baker, that we expect our dinner, but from their regard to their own interest."). Evolutionary biology helps us understand more fully and deeply why it is in the nature of man to be self-interested. See note 18 .

${ }_{316}$ The problem of rational disinterest in public policy information is even worse than might be initially thought. For the same reasons people are uninterested in paying attention to such information, they are rationally uninterested in training to understand it. Individuals invest in education and training in order to increase their return on human capital. See Gary S. Becker, Human Capital: A Theoretical and Empirical Analysis, with Special Reference to Education 15-44 (Natl Bureau of Econ Research 2d ed 1975). If they have no expectation of increasing their return by understanding public policy information, they will not educate themselves to understand it. This is one of the reasons that public policy debates in a democracy are conducted at such a low level.

${ }^{317}$ See Easterbrook, 107 Harv L Rev at 1331 (cited in note 107) (discussing this 
nal ignorance suggests yet another way in which public policy information differs from a public good like national defense or clean air. ${ }^{318}$ Unlike national defense and clean air, which citizens passively consume, additional information about public policy is useless unless citizens make the affirmative decision to act upon it. ${ }^{319}$ There is no evidence that regulation of the transmission media will change the average citizen's basic information calculus so as to encourage the consumption of more public policy information.

On the other hand, the regime of property rights in information transmission does its best to ameliorate civic ignorance. As the owners of information compete to package it in a form in which citizens will be interested, information becomes more accessible. The multiple networks of information also compete to provide the keys to understanding politicians' behavior, and the likely effects of that behavior on the citizen. Nevertheless, for reasons discussed above, the property-rights view of information transmission also recognizes that there may be inevitable constraints on the consumption of information for collective decision making in a mass democracy. ${ }^{320}$ That is one of the reasons that

second rationale of "rational ignorance"). Of course, people do vote even though their act of voting is less likely to determine the election than to land them in the hospital as a result of an accident on the way to the voting booth. See Mueller, Public choice II at 350 (cited in note 16) (discussing paradox of voting). The fact that an individual will perform an act in the public interest at small cost to himself does not suggest, however, that he will invest substantial time in pursuing the public interest. By analogy, people commonly provide small tips to service providers even when it is clear they will never meet the tippee again. People do not, however, commonly provide large sums of money to strangers with the expectation of receiving nothing in return. For low-cost acts of public spiritedness or charity, one is more likely to follow a custom because it is simply not worth the time and effort to constantly calculate whether to violate slightly burdensome social norms.

${ }^{318}$ See Sunstein, Democracy and the Problem of Free Speech at 68-71 (cited in note 28). See also text accompanying notes 310-16.

319 Professor Farber, in analogizing public policy information to a public good such as clean air, fails to note this important distinction. See Farber, 105 Harv L Rev at 567 (cited in note 30 ). This difference makes it much less likely that government decision makers will succeed in producing more of the good actually desired-public policy information to which citizens pay attention.

${ }^{320}$ If civic understanding in a democracy is inevitably limited, we might be better advised to think of ways of restructuring collective decision making so as to mitigate its natural defects, rather than distorting the real Madisonian vision of the freedom of speech. For instance, we might try to follow the example of the First Amendment and create traditions that would immunize other areas of social life from regulation. We might also resurrect the keystone of the Framers' structural design-federalism-and thereby decentralize collective decision making so that citizens would have a greater stake in decisions that affected them and would therefore pay more attention. See Robert Delahunty, From Ancient Liberty to the Welfare State, 1994 Pub Interest L Rev 181, 187, reviewing Cass R. Sunstein, The Partial Constitution (Harvard 1993) (suggesting that 
Framers such as James Madison who shared the property-rights view were correct in their understanding that the progress of civilization depended almost entirely on the spontaneous order created by property rights, including those in information transmission, and not on state intervention beyond action to enforce those rights. ${ }^{321}$

In contrast to those who view the First Amendment as a right of self-governance, those who understand the First Amendment as a right of self-expression would refuse to transform the Amendment from an individual right into an instrument for a collective good. ${ }^{322}$ They thus would instinctively agree with property theorists that the government should not be given greater power to regulate speech to promote democratic deliberation. ${ }^{323}$ Nevertheless, the property-rights perspective is a useful corrective to the self-realization theory as well, if we are to realize the full advantages of commercial speech promised by the expanding computer and telecommunication networks. Because mere commerce is somewhat distant from the concept of selfrealization (at least as understood by most academics), ${ }^{324}$ most self-realization theorists treat commercial speech as far inferior to political or artistic speech. ${ }^{325}$ A property-rights regime, however, suggests that commercial speech should be treated like political or artistic speech: commercial speech is no less the property of its producer than other kinds of speech. The property-based theory also more accurately tracks the role of information production in human nature. ${ }^{326}$ Most people are more concerned with real estate advertisements than political analysis or, one might

government power be devolved from the center to state and local entities "sufficiently small-scaled for individual citizens' participation in them to make a meaningful difference").

321 For discussion of the Framers' view of the way commerce and free speech would generate the benefits of civilization, see text accompanying notes 93-96.

${ }^{322}$ The literature on the First Amendment as a right of self-expression is voluminous. See, for example, Redish, $130 \mathrm{U}$ Pa L Rev at 591 (cited in note 12).

${ }_{323}$ The property theorist is able to advance stronger consequentialist arguments about why attempts to improve democratic deliberation through government regulation are likely to fail. See text accompanying notes 315-19.

324 See Rodney A. Smolla, Information, Imagery, and the First Amendment: A Case for Expansive Protection of Commercial Speech, 71 Tex L Rev 777, 783 (1993) (noting academic bias against commerce).

325 See Thomas H. Jackson and John Calvin Jeffries, Jr., Commercial Speech: Economic Due Process and the First Amendment, 65 Va L Rev 1, 5-6 (1979) (arguing that commercial speech should not be protected because it is irrelevant to both the collective selfgovernance and individual self-fulfillment rationales for the First Amendment).

${ }^{326}$ For a full discussion of the place of commercial speech in human nature, see McGinnis, Information Transmission (cited in note 23). 
add, the creative arts. ${ }^{327}$ They obtain at least as much satisfaction from the gains from trade that commercial speech facilitates as from the plays or political rallies they attend.

Even if commercial speech and political speech are equally protected by the First Amendment, it does not follow that commercial and political free speech doctrines would look identical. Under the Madisonian First Amendment, speech may be regulated to prevent harm to life and property of others. This justification for regulation is more often implicated by commercial than by political speech. For instance, if a politician intentionally misleads a group of individuals by promising a tax cut, and in reliance on this promise that group votes for him, the group has not been defrauded of property because citizens have the right only to the procedures the Constitution provides for setting taxes. These procedures include bicameral approval, and presentment to the President of all bills, including those on taxes, ${ }^{328}$ but they say nothing about the binding nature of campaign promises. On the other hand, outside of actions authorized by the political process, an individual has a right to protect his property against force or fraud, and thus the government may enforce that right by imposing civil or criminal liability on fraudulent commercial promises.

The property-rights vision would immunize commercial speech from regulation unless it threatens property through force or fraud; thus, it would substantially change current First Amendment doctrine in this area. The current First Amendment test permits the state to restrict commercial speech if: (1) the government interest justifying the regulation is substantial; (2) the restriction directly advances that interest; and (3) the restriction does so in a manner that provides a reasonable "ffit' between the legislature's ends and the means chosen to accomplish those ends." ${ }^{329}$ Such a test does not require that the regulation of speech be premised on some threat to property or life. Thus it can be applied to restrict even truthful advertising of the oppor-

327 See Daniel Seligman, Keeping Up, Fortune 107, 108 (Dec 28, 1992) (quoting Justice Scalia as saying: "Of the important decisions I've made in my life, certainly buying a house is enormously important. I mean, much more important to me than the latest state of the war in Bosnia.").

${ }^{328}$ US Const, Art I, § 7, cl 2.

329 See Board of Trustees of State University of New York v Fox, 492 US 469, 480 (1989), quoting Posadas de Puerto Rico Associates v Tourism Company of Puerto Rico, 478 US 328, 341 (1986). This test has been most recently reiterated -in Rubin $v$ Coors Brewing Co., 115 S Ct 1585 (1995) (invalidating federal law prohibiting beer containers from specifying their alcohol content). 
tunity to engage in otherwise legal conduct. ${ }^{330}$ By narrowly circumscribing regulatory power over speech to that necessary to prevent harm to life or property, a property-based interpretation of the First Amendment would lead to greater opportunities for commercial uses of the emerging information communication networks.

Interestingly, the expanding networks of information should ultimately prove more effective than the legal regimes of centralized authority in reducing commercial fraud. Fraud is an inevitable problem of human society, because the tendency to deceive is innate in man. ${ }^{331}$ Deception in human society decreases the overall wealth of society because individuals will less readily invest in the cooperation that creates wealth insofar as deception (and therefore promise breaking) is prevalent. ${ }^{332}$ Social mechanisms thus arise to restrain deception and enforce promises. ${ }^{333}$ Such social mechanisms fall along a broad spectrum from mechanisms depending on formal centralized authority to mechanisms that depend on less formal, more decentralized norms. ${ }^{334}$ The efficacy of centralized versus decentralized mechanisms is influ-

soo The Court in fact has restricted truthful commercial speech. See Posadas, 478 US at 344 (upholding restrictions on truthful lottery advertising); Florida Bar $v$ Went For It, Inc., 115 S Ct 2371, 2381 (1995) (upholding rule prohibiting lawyers from soliciting accident victims for thirty days after the accident).

331 Some deception will always be with us because deception is always a potential characteristic of relations between members of the same species who do not share precisely the same genes. See Robert Trivers, Social Evolution 395-420 (Benjamin/Cummings 1985). Deception is often adaptive in evolutionary terms because an individual, through deceiving another, can increase his resources or mating opportunities and so be in a better position to leave more progeny.

332 Deceit can decrease social wealth yet still be, in some circumstances, evolutionarily adaptive because natural selection operates on the individual rather than the group. See Richard Dawkins, The Selfish Gene 7-10 (Oxford 1976).

323 In addition to social mechanisms, evolution has structured our emotional life to make us reciprocal altruists who will fulfill obligations out of a sense of obligation, gratitude, or guilt. See Wright, Moral Animal at 189-209 (cited in note 17); Robert Axelrod, The Evolution of Cooperation 99 (Basic Books 1984) (suggesting that evolution would develop cooperative modes of behavior in order to get better results in iterated games of prisoner's dilemma where lack of cooperation would leave all participants worse off).

334 There is a growing literature on ways that decentralized mechanisms may spontaneously arise to discipline human behavior and enforce agreements in a fairly orderly way, even in the absence of a centralized coordinator. See Benjamin Klein and Keith B. Leffler, The Role of Market Forces in Assuring Contractual Performance, $89 \mathrm{~J}$ Pol Econ 615 (1981) (examining the value of repeat sales to consumers as a means of enforcing private contracts). The success of such decentralized enforcement systems may depend crucially on information costs-the costs of transmitting, storing, and accessing information. For discussion of other examples of the manner in which individuals create order without the benefit of a centralized coordinator, see Ellickson, Order without Law at 230264 (cited in note 148). 
enced by the costs of various activities, including the cost of exiting the community and the cost of disseminating information. ${ }^{335}$

For example, in hunter-gatherer societies it was difficult to leave the community and still survive. Acts of deception were therefore generally more costly to the deceiver than in the more mobile and anonymous societies that have characterized the West in the last millennium. ${ }^{336}$ These societies have had to rely more on centralized enforcement mechanisms until the cost of transmitting information declined, making it more cost effective to monitor the reputations of the transient population. For instance, when information costs were high, debtor prisons may have been necessary to enforce obligations. With lower information costs, much of the discipline in personal credit markets is imposed by information circulated by credit agencies. ${ }^{337}$

Today, as information costs fall still further, one can accumulate a broader array of data on people's past actions. Indeed, private entrepreneurs are already seizing the prospect of limiting deception through use of the Internet. ${ }^{338}$ The greater ease in evaluating people's integrity should deter deception across a wide range of activities just as access to credit ratings deters default on debts.

Of course, individuals may want to keep some information about themselves private. ${ }^{339}$ Contract can accomplish this objec-

${ }^{335}$ For another view of the way information costs bear on the structure of society, see Richard A. Posner, The Economics of Justice 147-50 (Harvard 1983). Posner seems to view changing information costs as the prime engine of social change. While I certainly agree that information costs are very important, I believe that other material changes such as increased mobility and population dispersion also play important roles.

${ }^{336}$ See Wright, Moral Animal at 38 (cited in note 17).

337 For a general discussion of the power of "relational" as opposed to purely legal sanctions in contract, see Stewart Macaulay, An Empirical View of Contract, 1985 Wis L Rev 465, 468-69.

${ }^{323}$ See Leslie Eaton, Gumshoes of Cyberspace Out to Save Investors Pain, NY Times D1 (Aug 18, 1994) (discussing use of the Internet to research public records, such as bankruptcy, arrest, and licensing records).

339 We can certainly expect legislative attempts to restrict such accumulation of information in the name of "privacy." Such efforts are generally misguided because they interfere with the valuable right of information transmission in order to enforce a concept of privacy that is scarcely coherent. When people say they want the state to keep information secret, what they really mean is that they want the state to protect their right to "selective disclosure of information." See Posner, Economics of Justice at 232-34 (cited in note 335) (arguing that individuals wish to manipulate what others know of them for their own personal gain). The so-called right of privacy (in the sense of a legal right to keep information secret) thus facilitates deception-one of the greatest natural barriers to value creation. Thus, so long as individuals obtain information without violating the property rights of others, they should generally be able to disseminate the information free from state interference. 
tive by permitting individuals to disseminate information for only limited purposes, thus preserving its privacy against the world in general. ${ }^{340}$ Modern technology may in fact make such privacy ultimately easier to enforce. Bits of information may be surrounded by other bits that will limit the list of people authorized to access the embedded bits to those legally entitled to do so. ${ }^{341}$ Cryptography also will help individuals keep information secret. $^{342}$ For instance, encryption will be used to authenticate and keep secret digital signatures that will permit the use of electronic cash, thus facilitating the commercial use of the net. ${ }^{343}$

Nevertheless, the information individuals do disseminate about themselves in the course of their transactions will be more efficiently gathered and organized. ${ }^{344}$ Thus, the global village may be creating conditions that better approximate the conditions of villages of hunter-gatherers where monitoring reputations was relatively easy. In addition to its many other virtues, the spontaneous order of the expanding net-particularly its commercial paths-can provide a decentralized mechanism for keeping us honest. ${ }^{345}$

${ }^{340}$ See note 141 (discussing the availability of contract to preserve retention value in information that is not subject to copyright).

31 See Negroponte, being digital at 15-17 (cited in note 246) (discussing the uses of bits).

342 For a comprehensive discussion of cryptography and the new communication technology, see Froomkin, $143 \mathrm{U}$ Pa L Rev 709 (cited in note 243). Like Professor Lessig, I am not as concerned about the concept of a "clipper chip" that allows the government to break the code and thereby eavesdrop on conversations. See Lawrence Lessig, The Path of Cyberlaw, 104 Yale L J 1743, 1751-52 n 23 (1995) (suggesting administrative methods that would prevent government abuse of the clipper chip). Indeed, since the government is permitted to eavesdrop on information transmitted in other modes (over phones or even spoken in one's own house) so long as it meets specified criteria, I do not believe a clipper chip is imposing special burdens on cyberspace in violation of the First Amendment, so long as the intercepts facilitated by the clipper chip meet similar Fourth Amendment criteria. But see Froomkin, 143 U Pa I Rev at 812-23 (arguing that clipper chip may violate the First Amendment).

${ }^{343}$ Froomkin, $143 \mathrm{U} \mathrm{Pa}$ L Rev at 720-21 (cited in note 243).

34 We can expect such information to accumulate. Individuals will naturally wish to retain the right to disseminate information about their course of transaction with others, so that they can release this information if the transaction goes badly. Retaining the right of dissemination is a kind of hostage-taking that may deter bad behavior by an individual's transactional counterpart. Compare Klein and Leffler, $89 \mathrm{~J}$ Pol Econ at 630-33 (cited in note 334) (suggesting that consumer-goods companies advertise to create a reputation that consumers can then hold hostage: quality is enforced by the danger that the corporate reputation will be eroded by consumer complaints about low-quality products).

345 Decentralized enforcement has important advantages over centralized enforcement because centralized enforcement concentrates power in institutions whose actions are difficult to discipline. Market forces generally do not discipline centralized enforcement 


\section{CONCLUSION}

Under the real Madisonian theory of the First Amendment, the government would have only a very circumscribed role with respect to the emerging networks of communication. This role would be limited largely to enforcing regulations that are applied to business enterprises generally. Given the great opportunities for competition among networks, spontaneous order of the kind represented by emerging computer nets will create multiple opportunities for information-rich exchanges.

Centralized authorities generally lack the information to improve on the beneficial competition among ideas that is intensified by a property-based First Amendment regime. Indeed, these centralized authorities have powerful incentives to distort that competition. Thus, in a world of global competition, societies that permit the government to regulate the flow of information are greatly disadvantaged compared with societies that continue to permit unfettered information transmission. The United States was one of the first republics ever to enshrine freedom of speech in its Constitution, a freedom originally understood as rooted in an individual's natural property right in his information. It is by returning to its roots that the First Amendment will best fulfill its promise in the age of an ever expanding network of telecommunications. 